\title{
Corrosion of Barrier Materials in Seawater Environments
}

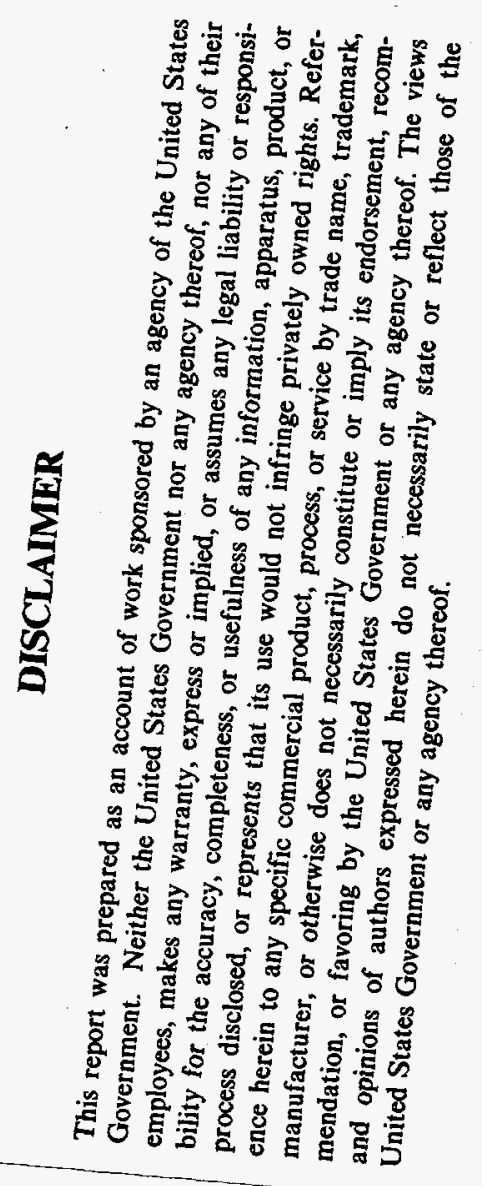

\author{
John H. Heiser \\ Peter Soo
}

July 1995

\section{Prepared for:}

Project Officer Robert S. Dyer

Office of Radiation and Indoor Air

Criteria and Standards Division

U.S. Environmental Protection Agency

Washington, DC 20460

Prepared by:

Environmental and Waste Technology Center

Department of Advanced Technology

Brookhaven National Laboratory

Associated Universities, Inc.

Upton, Long Island, New York 11973

This report was prepared as an account of work sponsored by

The United States Environmental Protection Agency under

Interagency Agreement No. DW 89936829-01-0

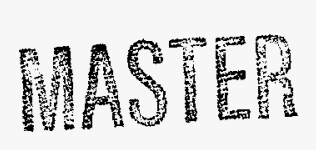





\section{DISCLAIMER}

Portions of this document may be illegible electronic image products. Images are produced from the best available original document. 


\begin{abstract}
A brief review has been carried out on the performance of barrier materials for low-level radioactive wastes in seawater environments. The environments include those for shallower coastal waters as well as the deep ocean (down to $3800 \mathrm{~m}$ ). The review is mainly focused on metallic materials since they are the most common for seawater service and they have the largest data base. Information from the literature is usually pertinent to shallower coastal locations, but there is a valuable source of corrosion data obtained from several studies of metallic specimens exposed to ocean-bed conditions. In addition, the corrosion of carbon steel barriers has been evaluated for actual waste containers that were retrieved from previously-used disposal sites in the Atlantic and Pacific Oceans. Of the metallic materials studied, carbon steel showed the least corrosion resistance. Failure by non-uniform attack in a typical waste container could occur in as little as $25 \mathrm{y}$ in some ocean environments. Penetration by local attack, such as pitting and crevice corrosion resistance was also observed for more expensive materials such as low-alloy steels, stainless steels, titanium alloys, zirconium alloys, copper alloys, nickel alloys, aluminum alloys, and lead alloys.
\end{abstract}




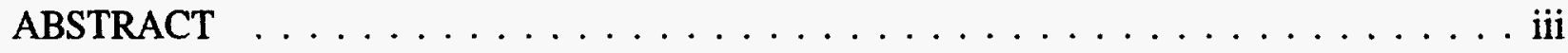

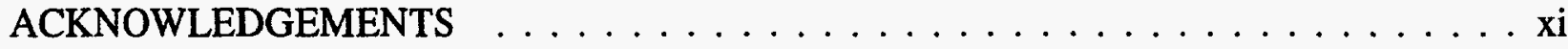

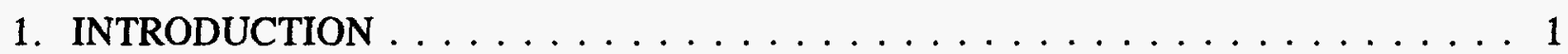

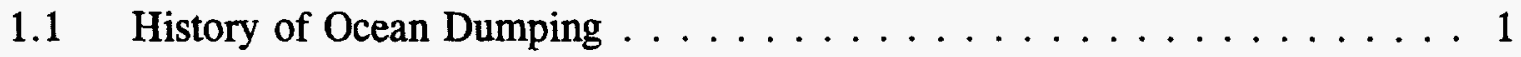

1.2 The Seawater Environment . . . . . . . . . . . . . . . 4

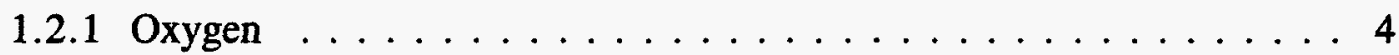

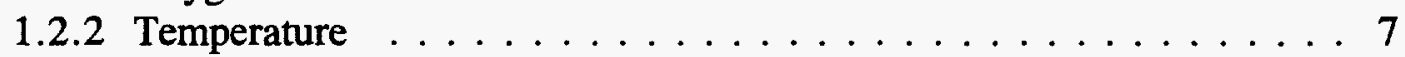

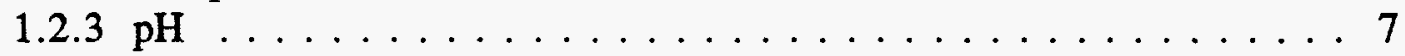

1.2 .4 Salinity .................... 7

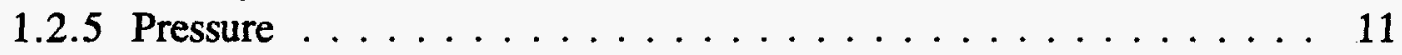

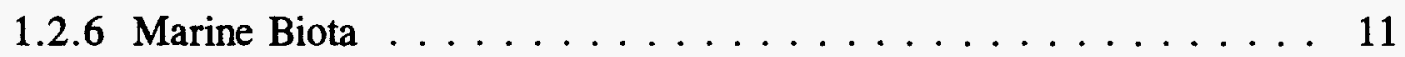

2. METALS AND ALLOYS $\ldots \ldots \ldots \ldots \ldots \ldots \ldots \ldots \ldots \ldots \ldots$

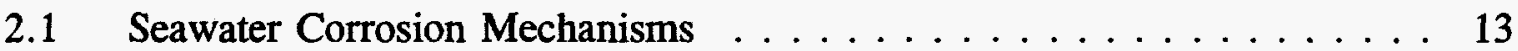

2.1.1 Uniform Corrosion . . . . . . . . . . . . . . 13

2.1.2 Pitting Corrosion $\ldots \ldots \ldots \ldots \ldots \ldots \ldots \ldots \ldots$

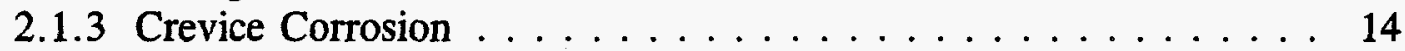

2.1.4 Galvanic Corrosion .................. 14

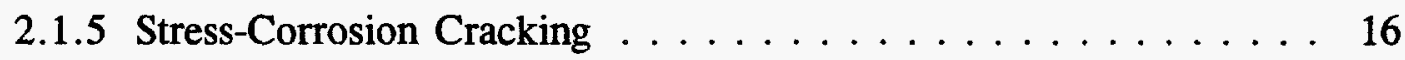

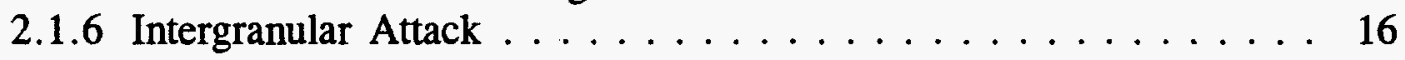

2.1.7 Hydrogen Embrittlement . . . . . . . . . . . . . 16

2.1.8 De-zincification or De-(metal)-ification $\ldots \ldots \ldots \ldots \ldots \ldots$

2.1 .9 Filiform Corrosion . . . . . . . . . . . . . . 16

2.2 Corrosion of Carbon and Low-Alloy Steels . . . . . . . . . . . . 17

2.2.1 Smaller-Scale Experiments . . . . . . . . . . . . . . 17

2.2.2 Full-Scale Tests . . . . . . . . . . . . . . . . . 31

2.3 Corrosion of Austenitic Stainless Steels . . . . . . . . . . . . . . 49

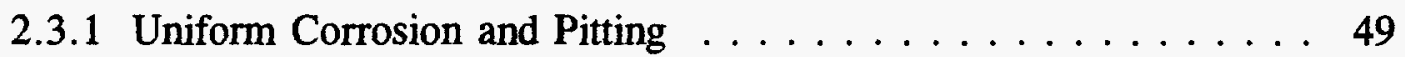

2.3.2 Crevice Corrosion . . . . . . . . . . . . . . 53

2.3.3 Stress-Corrosion Cracking . . . . . . . . . . . . 53

2.4 Corrosion of Titanium, Zirconium and their Alloys . . . . . . . . 59

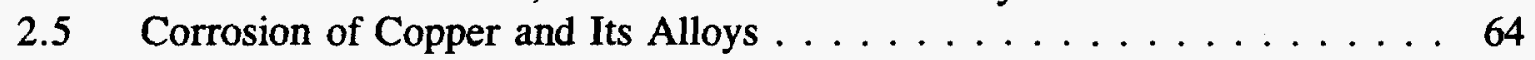

2.6 Corrosion of Nickel and Its Alloys $\ldots \ldots \ldots \ldots \ldots 6$

2.7 Corrosion of Aluminum and Its Alloys . . . . . . . . . . . 67

2.8 Corrosion of Lead and Its Alloys . . . . . . . . . . . . . . 67

2.9 Conclusions on the Use of Metallic Barriers . . . . . . . . . . . 68

3. CONCRETES . . . . . . . . . . . . . . . . . . . . . 69

$3.1 \quad$ Hydraulic Cement Concrete . . . . . . . . . . . . . . . 69

3.1 .1 Concrete Degradation . . . . . . . . . . . . . 70

3.1.2 Failure of Reinforced Concrete . . . . . . . . . . 73 
TABLE OF CONTENTS (cont.)

Page

$3.2 \quad$ Polymer-Impregnated Concretes (PIC) $\ldots \ldots \ldots \ldots \ldots \ldots \ldots$

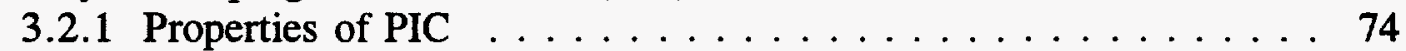

3.3 Conclusions on the Use of Concrete-Based Barriers . . . . . . . . . 75

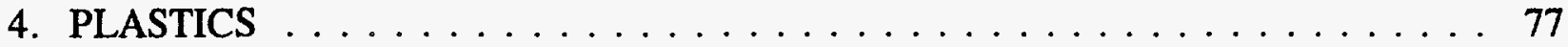

$4.1 \quad$ Failure Mechanisms of Plastics $\ldots \ldots \ldots \ldots \ldots \ldots \ldots 77$

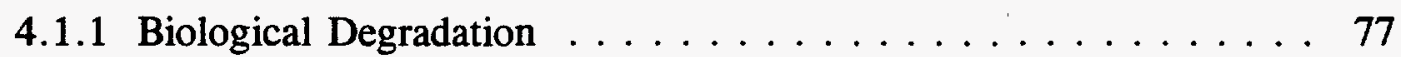

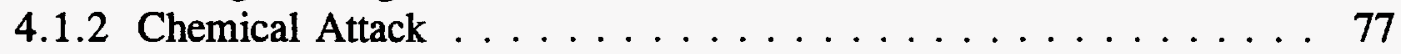

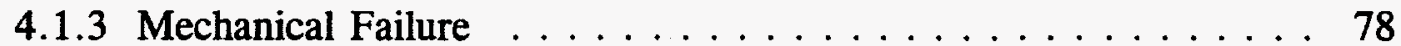

4.2 High Density Polyethylene $\ldots \ldots \ldots \ldots \ldots \ldots \ldots \ldots \ldots$

4.3 Conclusions on the Use of Polymeric Barriers . . . . . . . . . 79

5. OTHER BARRIER MATERIALS $\ldots \ldots \ldots \ldots \ldots \ldots \ldots \ldots \ldots \ldots$

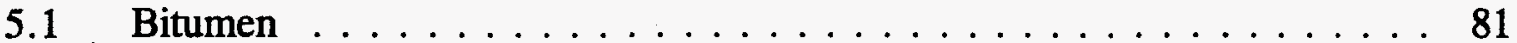

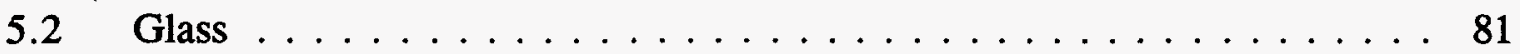

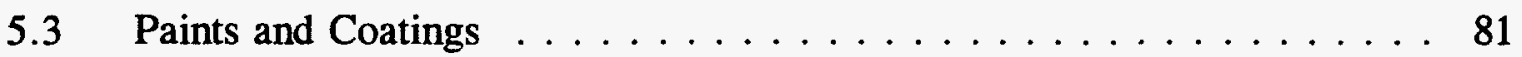

5.4 Conclusions on the Use of Other Barrier Materials . . . . . . . . 81

6. SUMMARY $\ldots \ldots \ldots \ldots \ldots \ldots \ldots \ldots \ldots \ldots \ldots \ldots$

REFERENCES . . . . . . . . . . . . . . . . . . . . . . . 87 
$\underline{\text { Page }}$

Figure 1.1 Waste package used in early ocean disposal. . . . . . . . . . . . . 2

Figure 1.2 Alternate type of waste package used for early ocean disposal . . . . . . . 3

Figure 1.3 Locations of samplings to determine variation in oxygen, temperature, salinity, and $\mathrm{pH}$ with depth $\ldots \ldots \ldots \ldots$

Figure 1.4 Variability of oxygen with depth in the North Atlantic and North Pacific . . 6

Figure 1.5 Variation of temperature with depth $\ldots \ldots \ldots \ldots \ldots$

Figure 1.6 Variation in $\mathrm{pH}$ with depth . . . . . . . . . . . . . . 9

Figure 1.7 Variation in salinity with depth . . . . . . . . . . . . 10

Figure 2.1 Effect of exposure time on corrosion of low alloy steels in seawater . . . 19

Figure 2.2 Change in corrosion rate and oxygen content with seawater depth for iron and low alloy steels . . . . . . . . . . . . . 20

Figure 2.3 Effect of oxygen on corrosion of cast irons and low alloy steel in seawater 21

Figure 2.4 Type 3 corrosion specimen assembly $\ldots \ldots \ldots \ldots \ldots \ldots \ldots \ldots$

Figure 2.5 Atlantic Ocean study locations . . . . . . . . . . . . . . . . 24

Figure 2.6 Penetration versus exposure time for irons and low alloys steels in seawater $\ldots \ldots \ldots \ldots \ldots \ldots \ldots \ldots \ldots$

Figure 2.7 Effect of pH on corrosion of iron and low alloy steel in seawater and $\mathrm{NaCl}$ solution . . . . . . . . . . . . . . . . . 29

Figure 2.8 Effect of seawater velocity on corrosion of low alloy steels . . . . . . 30

Figure 2.9 Average carbon steel corrosion rates in seawater calculated from weight

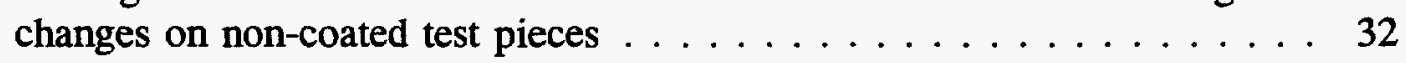

Figure 2.10 Major U.S. radioactive waste disposal sites in the Atlantic Ocean . . . . 34

Figure 2.11 Farallon Islands radioactive waste disposal sites . . . . . . . . . . 35

Figure 2.12 An exterior view of the upper portion of the container (sea facing side) retrieved from the $2800 \mathrm{~m}$ Atlantic site . . . . . . . . . 38

Figure 2.13 An exterior view of the upper portion of the container (sediment facing side) retrieved from the $2800 \mathrm{~m}$ Atlantic site . . . . . 39

Figure 2.14 A typical metallographic cross section of the upper portion of the container retrieved from the $2800 \mathrm{~m}$ Atlantic site . . . . . . . . . 40

Figure 2.15 A typical metallographic cross section of the lower portion of the container retrieved from the $2800 \mathrm{~m}$ Atlantic site . . . . . . . . . . 41

Figure 2.16 An exterior view of general attack adjacent to a chime within the mid-section of the waste container from the $2800 \mathrm{~m}$ Atlantic site . . . . .

Figure 2.17 An example of filiform corrosion on the waste container from the $2800 \mathrm{~m}$ Atlantic site . . . . . . . . . . . . . . . . . . . . 43

Figure 2.18 Retrieval operations using Alvin's mechanical arm to place a metal harness around the waste package at the $3800 \mathrm{~m}$ Atlantic site . . . . . .

Figure 2.19 Close view of severe general attack on sediment side compared to the more protected sea side. Container retrieved from the $3800 \mathrm{~m}$ Atlantic site . . 45

Figure 2.20 Severe general pitting below the sediment line. Container retrieved from the $3800 \mathrm{~m}$ Atlantic site . . . . . . . . . . . . . . . . . 46

Figure 2.21 Close view of rim perforations on container retrieved from the $3800 \mathrm{~m}$

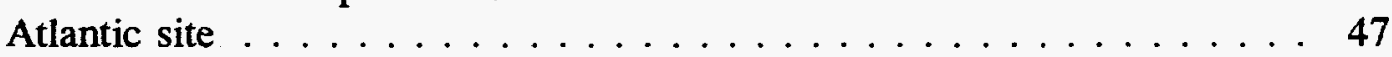




\section{LIST OF FIGURES (cont.)}

Page

Figure 2.22 Photograph of inner side of container from the $3800 \mathrm{~m}$ Atlantic site after removal from concrete. Perforations appear near rim of the chimes and

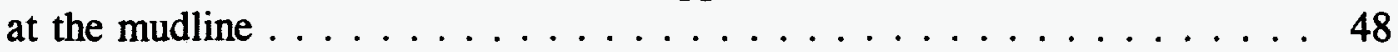

Figure 2.23 Cut away isometric views showing modifications of 55-gallon drums for packaging radioactive wastes which were disposed of in the Farallon Islands $900 \mathrm{~m}$ disposal site . . . . . . . . . . . . . . . 50

Figure 2.24 Effect of exposure time on the penetration of stainless steels as determined from weight-loss measurements . . . . . . . . . 56

Figure 2.25 Influence of temperature, chloride content and $\mathrm{pH}$ value on crevice corrosion and pitting of unalloyed titanium $\ldots \ldots \ldots \ldots 60$

Figure 2.26 Effect of exposure time on corrosion of copper metals in an ocean environment ...................... 65

Figure 3.1 Effect of water/cement ratio on permeability $\ldots \ldots \ldots \ldots \ldots \ldots$

Figure 6.1 Proposed multibarrier waste package . . . . . . . . . . . . . 84

Figure 6.2 Steel waste container set in concrete container $\ldots \ldots \ldots \ldots \ldots$ 


\section{LIST OF TABLES}

$\underline{\text { Page }}$

Table 2.1 Galvanic Series of Metals and Alloys in Seawater . . . . . . . . . . 15

Table $2.2 \quad$ Steel Compositions - Percent . . . . . . . . . . . . . . . . . 18

Table 2.3 Corrosion Rates of Steels in Sea Water . . . . . . . . . . . . . . 18

Table 2.4 Deployment and Recovery of Corrosion Experiments . . . . . . . . . . 25

Table 2.6 Corrosion Rates (Mils/Year) of ASTM A516 Carbon Steel in Contact with Stainless Steel (CRES 308) . . . . . . . . . . . . . . . 27

Table 2.7 Corrosion Amounts, Corrosion Depth and Average Corrosion Rates for Seawater Calculated from Weight Changes of Non-Coated Carbon Steel Test Pieces . . . . . . . . . . . . . . . . . . . 33

Table 2.8 Local Thickness Change and Local Corrosion Rates for Non-Coated Carbon Steel Test Pieces . . . . . . . . . . . . . . . . . . 33

Table 2.9 Primary United States Ocean Disposal Sites for Low-Level Radioactive Waste . . . . . . . . . . . . . . . . . . . . . . . . 36

Table 2.10 Corrosion Rate Data for Waste Packages Retrieved from Deep Sea Disposal Sites . . . . . . . . . . . . . . . . . . . . . . 51

Table 2.11 AISI and ACI Standard Composition Ranges for Wrought and Cast Chromium-Nickel Stainless Steels American Iron and Steel Institute. Classification of Chromium-Nickel Stainless Steels . . . . . . . . . 52

Table 2.12 Comprehensive Evaluation of Corrosion Damage of Stainless Steels, Exposed to Marine Environment in the Panama Canal Zone . . . . . . . . 54

Table 2.13 Corrosion Behavior of Austenitic Stainless Steels in Seawater Moving

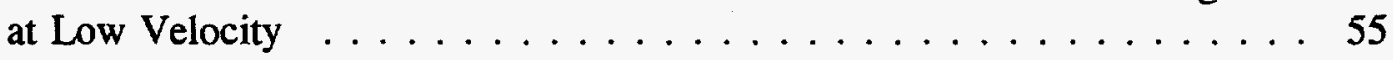

Table 2.14 Influence of Composition on Pitting Corrosion of Austenitic Stainless Steels in Low Velocity Seawater at Ambient Temperatures . . . . . . . 56

Table 2.15 Corrosion Rates (mils/year) of Stainless Steel and Alloy 600 . . . . . . . 57

Table 2.16 Seawater Crevice Corrosion Behavior of Austenitic Stainless Steels . . . 58

Table 2.17 Compositions of Zircaloy 2 and Zircaloy $4 \ldots \ldots \ldots$. . . . . . 61

Table 2.18 Corrosion Rate of Candidate Materials in Seawater and Sediments

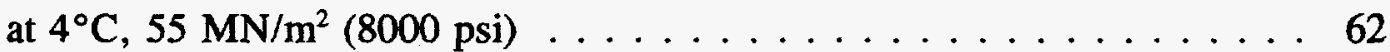

Table 2.19 Corrosion Rate of Candidate Materials in Seawater and Sediments at $25^{\circ} \mathrm{C}, 55 \mathrm{MN} / \mathrm{m}^{2}(8000 \mathrm{psi}) \ldots \ldots \ldots \ldots \ldots \ldots$ 


\section{ACKNOWLEDGEMENTS}

The authors gratefully acknowledge Prof. N. Fisher of the State University of New York at Stony Brook for his contributions to Section 1.2 of this report on seawater environments. Dr. Robert S. Dyer of the U.S. Environmental Protection Agency is acknowledged for his review of the report and his helpful suggestions. Ms. Laura Ayres was responsible for preparing the manuscript. 


\section{INTRODUCTION}

The United States is committed to the protection of the marine environment under the 1972 Convention on the Prevention of Marine Pollution by Dumping of Waste and Other Matter. This commitment is enforced domestically by Public Law 92-532, the Marine Protection Research and Sanctuaries Act of 1972, as amended, which also establishes the Environmental Protection Agency (EPA) as the regulatory authority for U.S. ocean dumping. The Act prohibits the disposal of radioactive wastes in the ocean.

\subsection{History of Ocean Dumping}

Ocean dumping of low-level radioactive waste was practiced in the United States between 1946 and 1970 and abroad between 1946 and 1986 . It was initially authorized by the U.S. Atomic Energy Commission (AEC) and involved over 35 sites in the Atlantic, Pacific and Gulf of Mexico [1]. The United States discontinued ocean disposal in 1970 primarily because the AEC decided to use shallow-land burial of wastes and because the Council on Environmental Quality recommended prohibition of sea dumping unless no other disposal method offered less risk.

The U.S. dumped in excess of 60,000 curies of low-level wastes in coastal and offshore water at depths between about $15-5000 \mathrm{~m}$ [1]. The containers used were mostly of 55 gallon capacity and were weighted with cement to ensure that they would sink.

Other nations also had active ocean disposal programs including the United Kingdom, France, Japan and the former Soviet Union. The British disposed of about 47,000 curies of alpha- and beta-emitting wastes near the Bay of Biscay and the Hurd Deep north of the island of Guernsey in the Channel Islands [1]. Soviet wastes were disposed in the Barents and Kara Seas in the Arctic. The Novaya Zemlya trench in the Kara Sea is about $450 \mathrm{~m}$ deep.

After assuming authority for ocean disposal, the EPA conducted surveys at sites in the Atlantic and Pacific by retrieving drums of waste for evaluation. Four sites in these oceans were mainly used, and about $95 \%$ of U.S. wastes are located in these areas. Containers used for the wastes were usually painted 55-gallon carbon steel drums. They were filled with solid wastes or mixtures of waste and cement, and were "capped" with clean cement. The cement had the added function of ensuring that the drums would not float. Figures 1.1 and 1.2 show crosssections through typical waste packages. Work at Brookhaven National Laboratory (BNL) on the drums retrieved from three sites showed that the waste contents had not degraded appreciably, although the steel drums had suffered perforation early in service (precise times not determinable) $[2,3,4]$.

Since wastes in the past have been disposed in shallow as well as deep ocean environments, it is important to define any variations in seawater conditions as a function of depth. This will help in understanding, for example, any changes in metal corrosion that might occur at different depths because of differences in oxygen level, $\mathrm{pH}$, temperature, biofouling, and water flow rate. These factors are discussed below. 


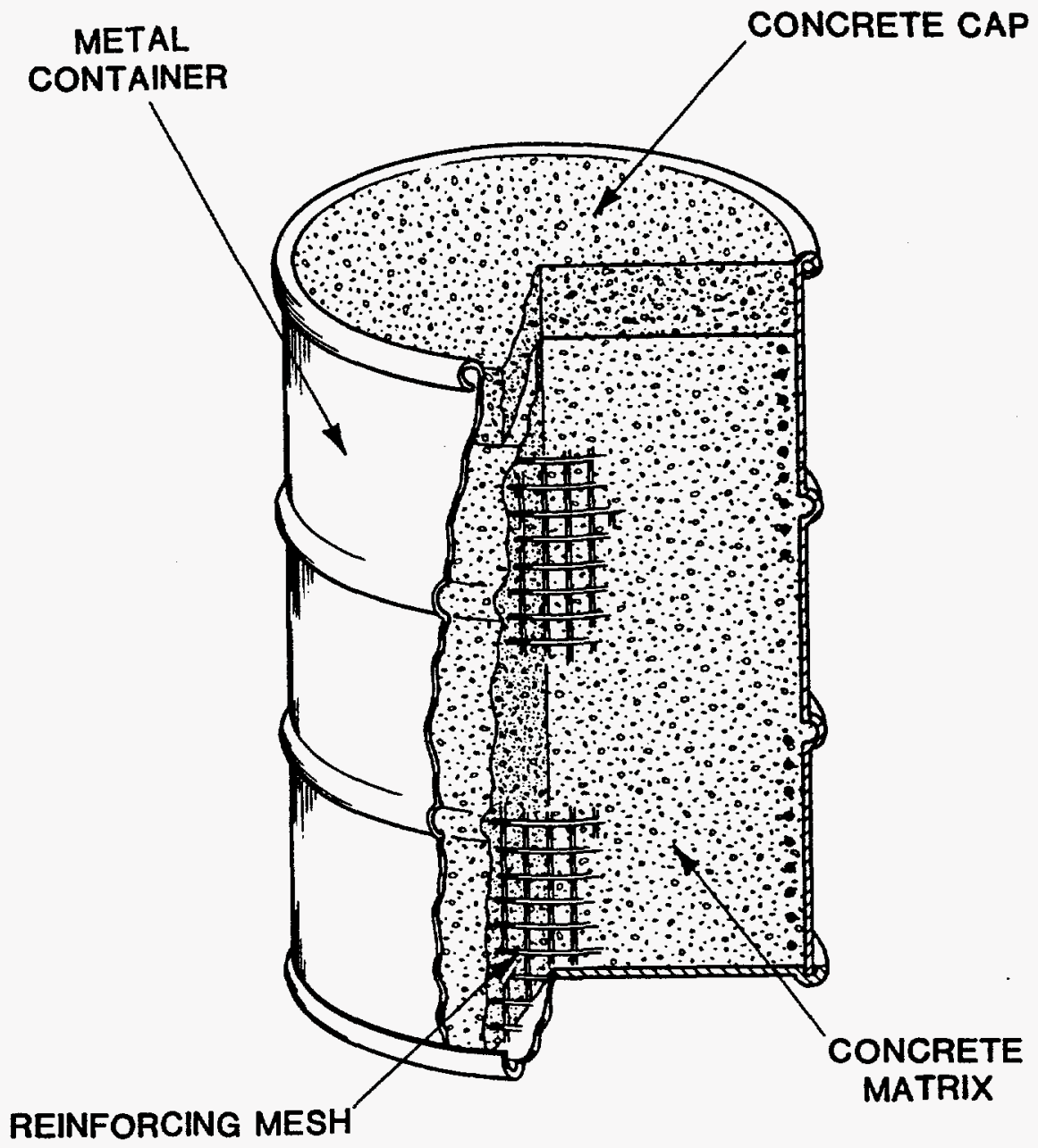

Figure 1.1 Waste package used in early ocean disposal. 


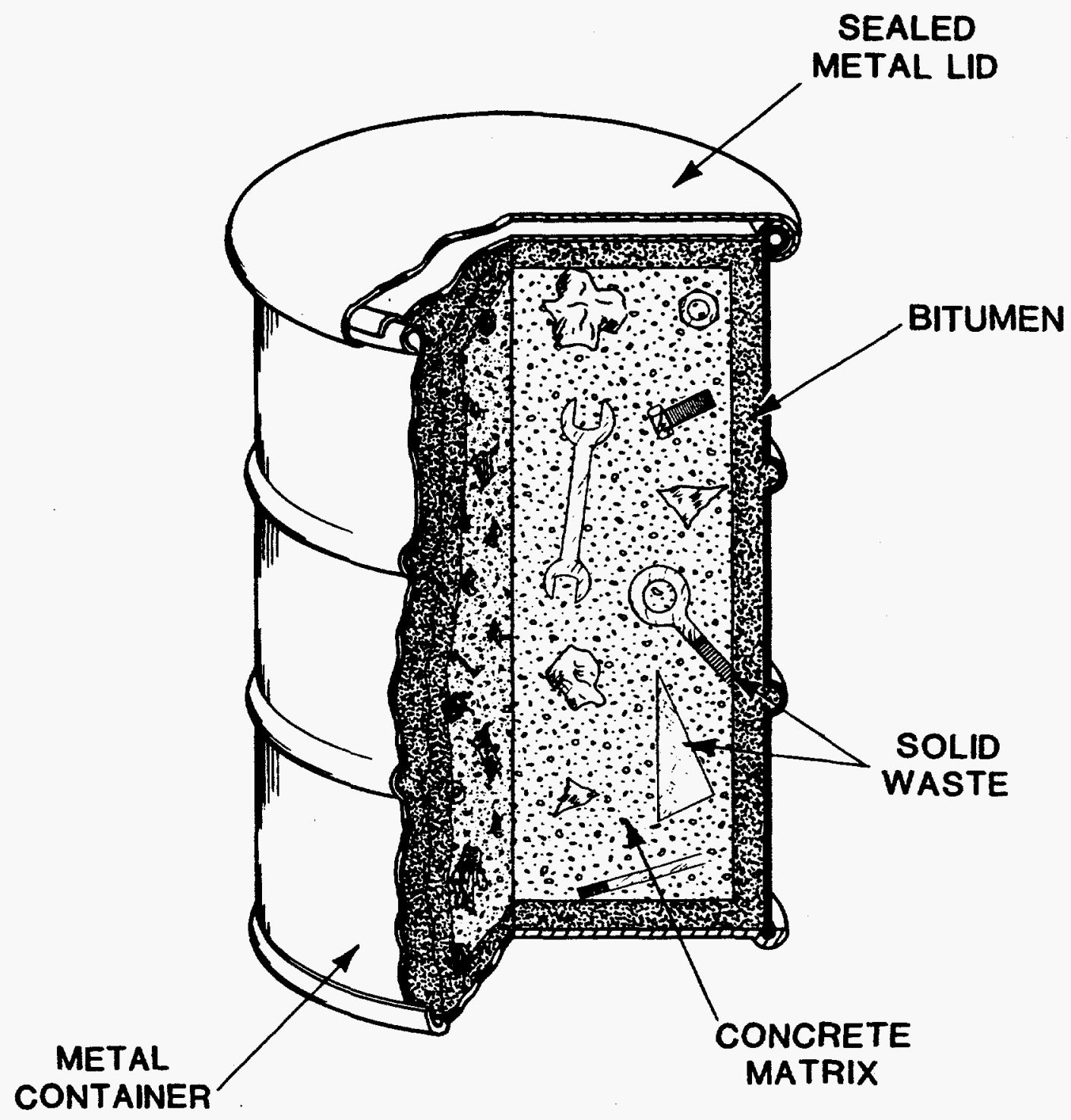

Figure 1.2 Alternate type of waste package used for early ocean disposal. 


\subsection{The Seawater Environment}

Continental shelf waters are typically more variable in their physical and biological attributes than the deep ocean. Two of the most important physical factors influencing the bottom environments are turbulence and wave action. Turbulence can be created by the interactions of waves, currents, upwelling and storm. Waves (e.g., long period ocean swells and storm waves) also have significant impact on the bottom of shallow waters. The bottom substrates are generally comprised of muddy and sandy sediments. The generation of waves and turbulence will resuspend sedimentary particles, thus greatly affecting the stability of the substrate and the biological communities within the sediment-water interface. Furthermore, wave action also influences the type of particles present in the sediments. When wave action is strong, fine sediments are resuspended, leaving the sediments coarser. Therefore, fine sediments are commonly found in areas that have low wave action or are too deep to be affected by wave action.

Thus, in contrast to the deep oceans, which are controlled by deep water circulation and are relatively stable over time, bottom environments on the shelf are more localized and any change can be episodic, largely controlled by the wave action and turbulence. In waters intermediate between the shelf and the deep ocean are the continental rise with depths extending from a few hundreds of meters to thousands of meters. Wave action and turbulence decrease with depth, but the presence of a nepheloid ("cloudy") layer also indicates the presence of turbulence or contour currents in these bottom environments. Resuspension of sediments can be caused by internal waves on the shelf slope. Furthermore, sedimentary structures are not stable. Sediments can be transported further down to the deep ocean by downslope transport mechanisms (slumping and sliding) or by turbidity currents.

Factors affecting the lifetime of materials exposed to seawater include dissolved oxygen, temperature, $\mathrm{pH}$, salinity, sulfates, pressure, and marine life (biofouling) [5-8]. These are briefly discussed below.

\subsubsection{Oxygen}

Oxygen levels in continental shelf environments are largely controlled by the biological activity and show strong seasonal variation [5]. In the summer, degradation of biological debris (deriving ultimately from surface primary productivity, often involving a spring bloom in temperature regions) and increased infaunal abundance cause a reduction in oxygen levels in the benthos. During the winter, greater turbulence and wave action (e.g., storms), and the decline in infaunal biological activity (due to the reduction of food supply) lead to an increase in oxygen consumption; thus oxygen levels are higher in winter than in summer. Dissolved oxygen is probably the most important deep ocean parameter since corrosion is the primary failure mechanism for many candidate barrier materials [5,8]. In the Pacific, the retention time of ocean waters is longer than it is in the Atlantic; therefore, more of the dissolved oxygen is consumed by decaying organics [5]. As a result, there is considerably more oxygen in the deep Atlantic than in the deep Pacific. Figure 1.3 shows the locations of four sites from which oxygen levels were measured as a function of depth. The results given in Figure 1.4 show that the minimum in dissolved oxygen does not occur at the greatest depth, but somewhere near 1000-1500 meters. 


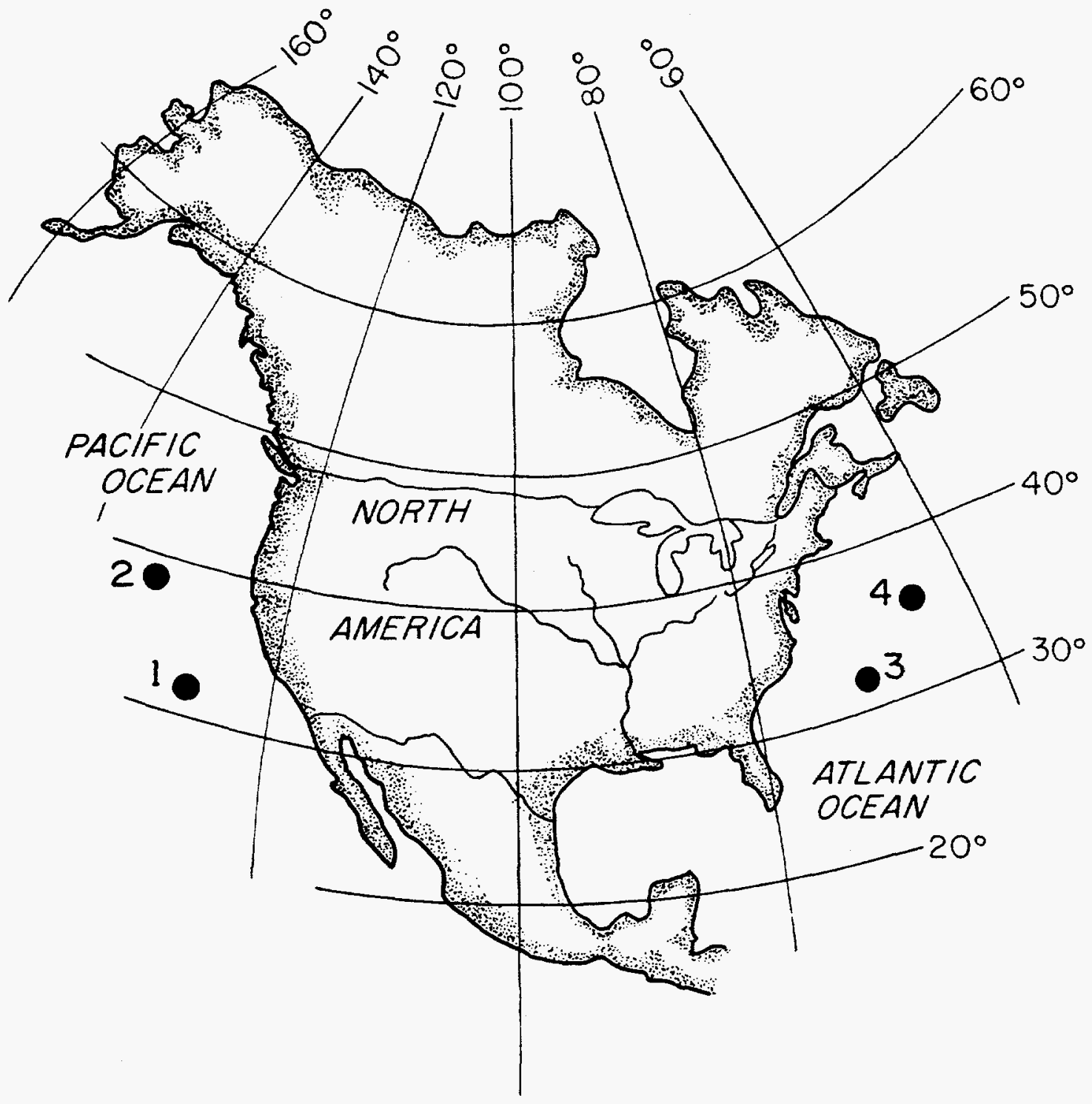

Figure 1.3 Locations of samplings to determine variation in oxygen, temperature, salinity, and $\mathrm{pH}$ with depth [5]. 


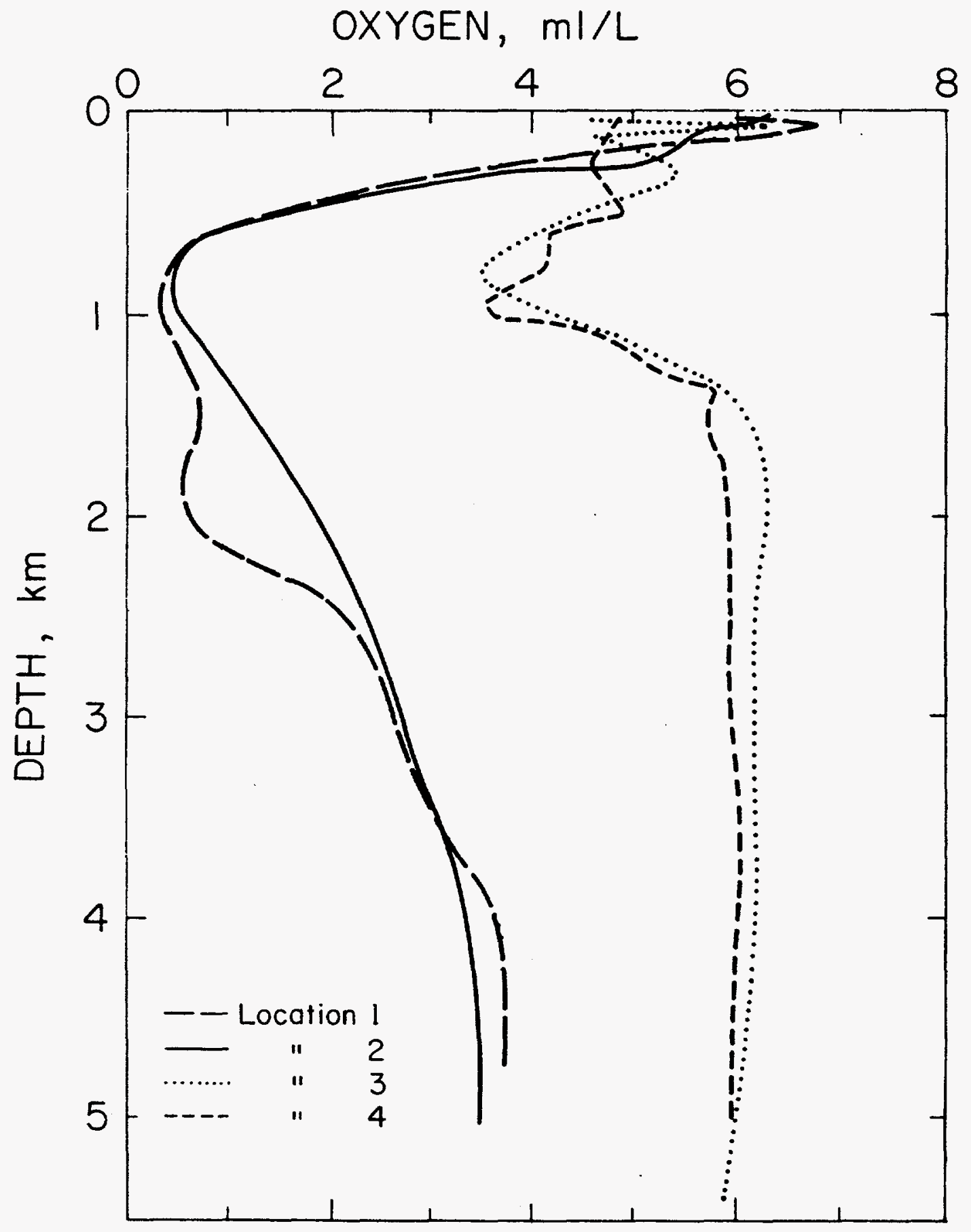

Figure 1.4 Variability of oxygen with depth in the North Atlantic and North Pacific [5,8]. Location defined in Figure 1.3. 


\subsubsection{Temperature}

Temperature in surface waters is variable and shows pronounced seasonal changes in temperate regions. In deeper waters the temperature shows less variability. At ocean depths below $4000 \mathrm{~m}$ the temperatures in both the Atlantic and Pacific remain in the range of $3-6^{\circ} \mathrm{C}$ throughout the year. These low temperatures tend to retard most failure modes (i.e. corrosion) but may cause materials to become more brittle (e.g., plastics). Figure 1.5 shows the temperature profile with depth at the locations shown in Figure 1.3.

\section{$1.2 .3 \mathrm{pH}$}

The $\mathrm{pH}$ in seawater environments is affected by biological activity, such as the decay or organic matter, photosynthetic activity of phytoplankton, and the respiratory activity of benthic animals. As a result, there can be seasonal changes in $\mathrm{pH}$ in the bottom environments of shallow shelf waters. During the summer, with the decomposition or organic matter and increased infaunal activity, more carbon dioxide is produced, which may produce slightly acidic conditions. These conditions are not stable, however, and the $\mathrm{pH}$ becomes basic as the biological respiration diminishes.

Deep ocean $\mathrm{pH}$ is relatively constant at different locations and in most cases follows the oxygen content. The deep Pacific is thereby slightly more acidic (by $0.15-0.40 \mathrm{pH}$ units) than the deep Atlantic due to increased biological activity [5] (Figure 1.6). For most materials, slight $\mathrm{pH}$ differences over the ranges shown in Figure 1.6 will have little effect on barrier lifetime. Formation of calcareous scales are also affected by $\mathrm{pH}$ and can alter corrosion rates of some metals (i.e. irons and low alloy steels).

\subsubsection{Salinity}

Salinity in shallow waters is also more variable than in the deep ocean due to the input of freshwater from river. However, with the exception of areas near the discharge of large river systems, salinity does not change much in the bottom environments of shelf waters. Salinity may strongly affect the electrolytic and corrosive characteristics of seawater. It is normally calculated from measured chloride content or electrical conductivity [5]. Chloride ions can promote break down of passive films on metals. The electrolytic characteristics are due to the amount of ions (salinity) in seawater. This determines how much separation between anodic and cathodic sites on the metallic surfaces (hence, ease of initiation of corrosion) is possible. Salinity at deep ocean sites is between 34.5 and 35ppt. ${ }^{(1)}$ Figure 1.7 gives data on salinity versus depth and location. These differences in salinity between locations will have negligible effects upon lifetime or corrosion and will contribuie little to barrier failure mechanisms.

(1) Parts per thousand. 


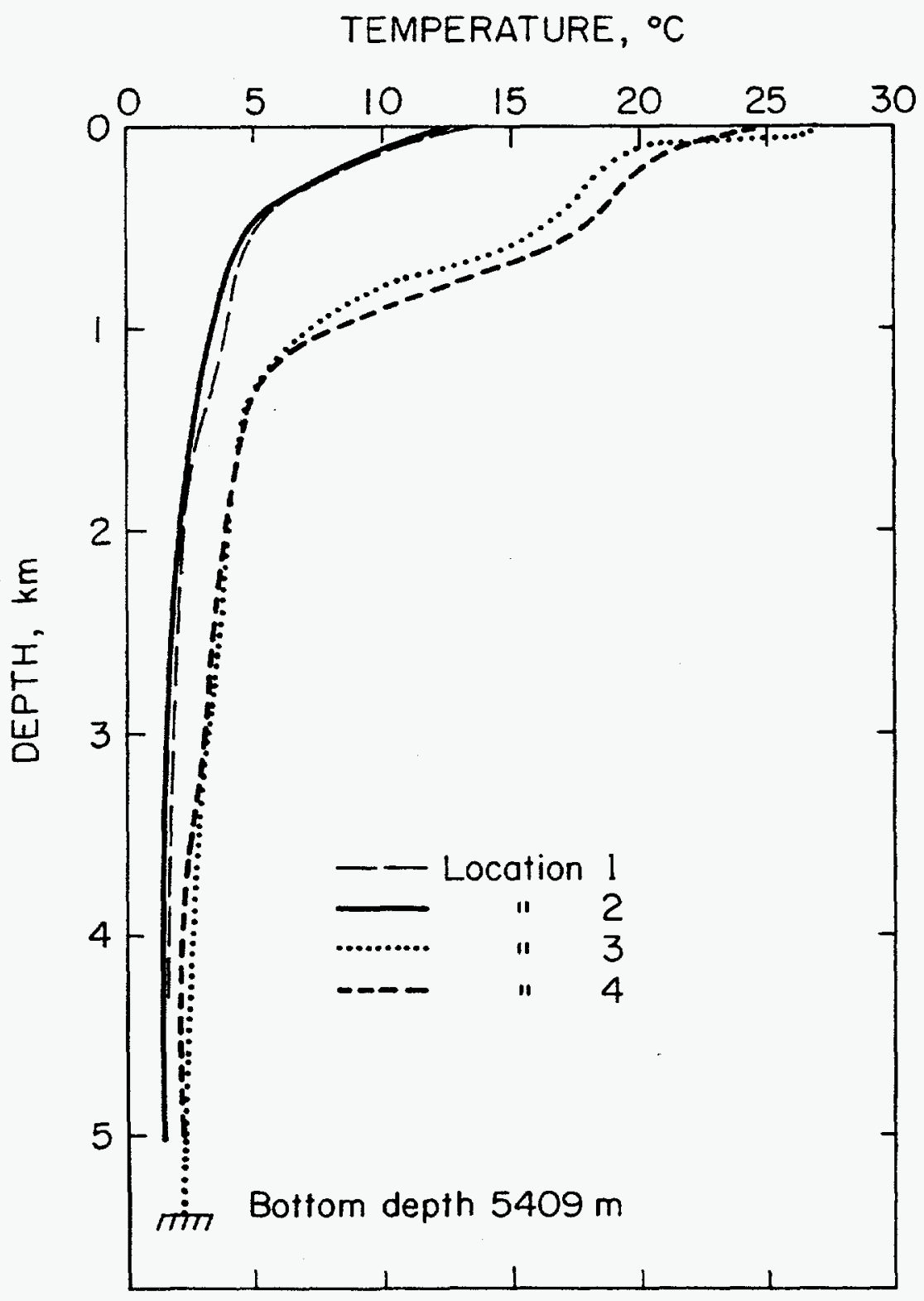

Figure 1.5 Variation of temperature with depth $[5,8]$. Locations defined in Figure 1.3. 


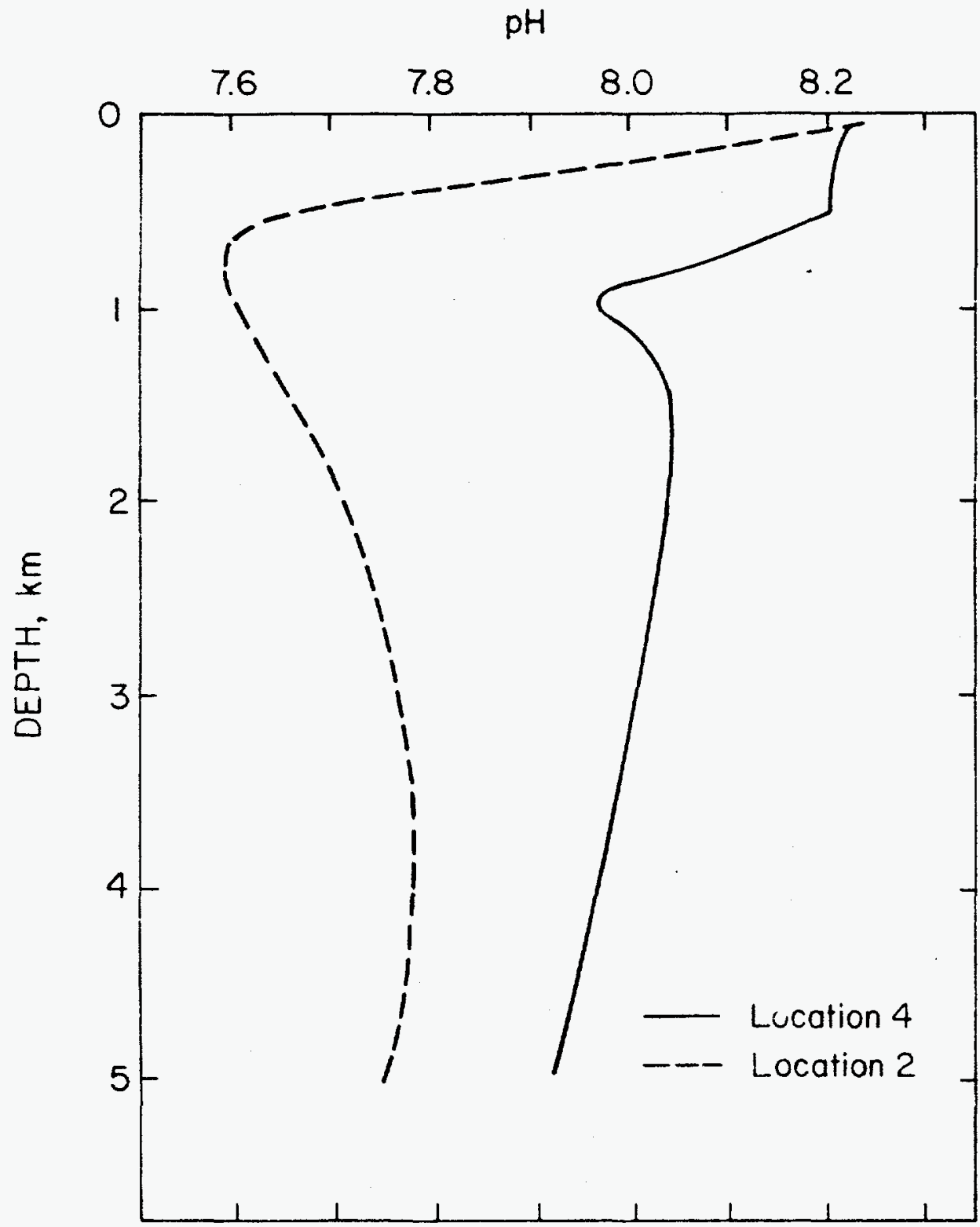

Figure 1.6 Variation in pH with depth [5].

Locations defined in Figure 1.3. 


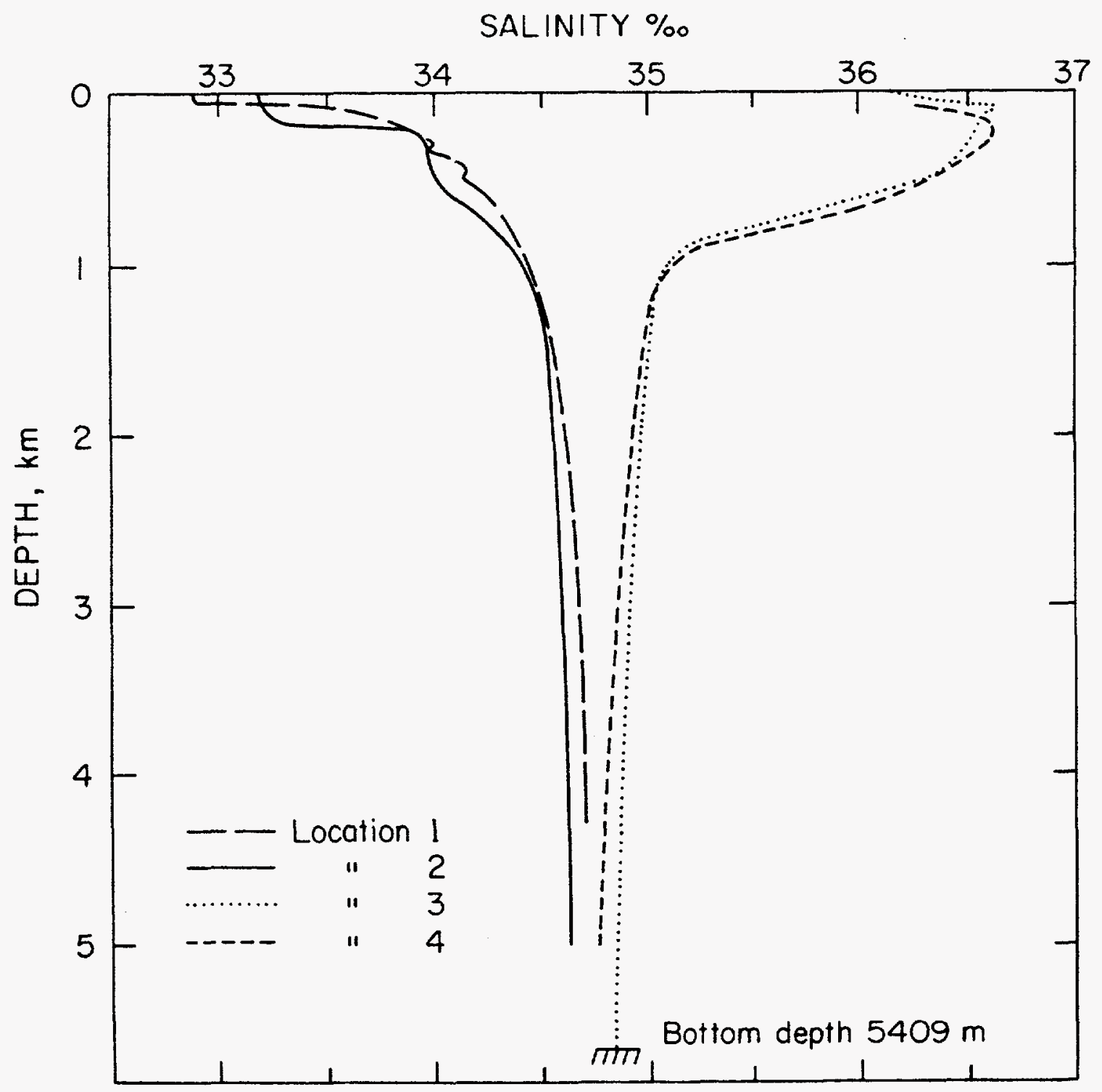

Figure 1.7 Variation in salinity with depth $[5,8]$.

Locations defined in Figure 1.3. 


\subsubsection{Pressure}

At deep ocean disposal sites pressures in excess of $400 \mathrm{~kg} / \mathrm{cm}^{2}$ will be encountered. This requires the design engineer to develop a canister/waste form package capable of withstanding high, long-term hydrostatic forces. Colombo, et al. calculated that a waste form having a minimum uniaxial compressive strength of $150 \mathrm{~kg} / \mathrm{cm}^{2}$ (2133 psi) will withstand these pressures [2]. High pressures will greatly enhance seawater permeation into some barrier materials (i.e. cement, plastics, etc.), so that care will be needed to ensure that this does not lead to disintegration.

\subsubsection{Marine Biota}

The biological communities in continental shelf environments are often more active and abundant than those found in the deep ocean, although the species diversity can be greater in the stable deep-ocean benthic communities. A more abundant food supply (due to increased primary productivity) increases the abundance of benthic animals. In contrast to benthic communities in the deep ocean which are dominated by deposit feeders, the shelf bottom communities are dominated by both suspension feeders and deposit feeders. The life history of some benthic invertebrates can also differ greatly between the open ocean and shelf bottom environments. In the deep ocean, life histories of infaunal animals mainly involve direct or lecithotrophic (rely on nutrients contained in eggs only) development because of the scarcity of food supply. The dispersal ability of larvae, if any, is limited. In contrast, in shelf environments development may be dominated by planktotrophic stages; larvae are able to disperse for a relatively long period of time, which is necessary for larvae to obtain external food sources. Once the settling larvae find a suitable substrate, they settle and commence adult life stages. Thus, biofouling of containers may be present in these environments. Biofouling can cause accelerated failure of some materials (stainless steels, $\mathrm{Cu}-\mathrm{Ni}$ alloys, etc.) and reduced failure rates on others (irons, low alloy steels, etc.). The amount of biofouling in the deep ocean is expected to be small, however, and have little effect on barrier lifetime.

In conclusion, deep ocean parameters are near constant with time and change little with location. Once characterized, a selected disposal site can be expected to retain its characteristics throughout the expected barrier lifetime. Only dissolved oxygen shows substantial changes with location (not time) and then only in different oceans. For more complete discussions on ocean environments see references 5,6 and 7 .

In the following sections of this report, the different classes of materials that may be used for seawater barriers will be discussed. 


\section{METALS AND ALLOYS}

Metals and alloys are the best documented barrier materials for marine use. They have favorable properties such as high strength, fabricability, availability, and are usually cost effective. The most important factor governing the selection of a metallic barrier is its ability to withstand seawater corrosion over the design lifetime. Secondary factors include mechanical properties to withstand transportation and service stresses, material and fabrication costs, and barrier design. In this section, emphasis will be placed on a review of corrosion data for common engineering barrier materials, including low-carbon steels, low-alloy steels, stainless steels, and a range of other alloys. Some of the more general descriptions of seawater corrosion are given in references 8 through 17 . More specific information is discussed below.

\subsection{Seawater Corrosion Mechanisms}

In discussing seawater corrosion and barrier life, consideration must be given to those modes of attack that are applicable for the materials of concern under expected ocean conditions at a disposal site. The following corrosion mechanisms are considered to be relevant to seawater conditions: uniform (general) corrosion, pitting, crevice corrosion, galvanic corrosion, stresscorrosion cracking, intergranular corrosion, de-zincification for brass, and filiform corrosion.

Aqueous corrosion of a metal is an electrochemical process in which parts of the metal surface are anodic and other parts are cathodic. At anodic sites, metal ions pass into solution:

$$
M-\mathrm{ne}^{-}=\mathbf{M}^{\mathrm{n}+}
$$

At cathodic sites, in the presence of dissolved oxygen in water, the following reaction occurs:

$$
\mathrm{O}_{2}+2 \mathrm{H}_{2} \mathrm{O}+4 \mathrm{e}^{-}=4 \mathrm{OH}^{-}
$$

Electrons are donated from the anodic reaction by travelling through the metal surface. The metal ions travel through the electrolyte to the cathodic areas where they usually form insoluble metal hydroxide corrosion products. The anodic and cathodic reactions are coupled and if one reaction is unable to proceed for any reason, the other also ceases. Individual corrosion mechanisms are briefly discussed below.

\subsubsection{Uniform Corrosion}

Uniform corrosion, as implied, is distributed evenly over the metal surface. Anodic and cathodic areas are present and are usually able to move from location to location as corrosion proceeds [18]. In most cases, the corrosion rate decreases with time and reaches a steady state value. This is controlled by the presence of corrosion products that form a semi-protective layer on the metal surface. The layer acts as a diffusion barrier through which metal ions and oxygen must diffuse during the corrosion process. 


\subsubsection{Pitting Corrosion}

Pitting occurs at localized areas of the metal surface and may lead to rapid penetration of a barrier. The mechanism is caused by the perforation of a "passive," usually oxide, film on the metal. This region becomes anodic while the large area of material around this site is cathodic. After pit initiation, the anodic and cathodic areas remain in place. The large cathodic area results in rapid metal dissolution in the pit. Chloride in seawater is a major factor in the breakdown of passivity in a metal surface. As chloride concentrates in the pit the $\mathrm{pH}$ decreases, causing an initial increase in the rate of attack in the pit $[19,20]$. As the pits fill with corrosion products, the rate of pit growth decreases.

It has been found that the pit depth is often proportional to the thickness of the uniformlycorroded layer. This has led to the definition of a "pitting factor" which is the ratio of the maximum pit depth to the average uniform corrosion penetration as determined by descaled weight loss measurements [21]. Clearly, those metals that have a high pitting factor would not be optimum choices for seawater service.

\subsubsection{Crevice Corrosion}

Crevice corrosion is similar to pitting in that it is localized attack with fixed anodic and cathodic regions. It occurs in areas where free flow of electrolyte is restricted. These include mated surfaces, threaded fasteners, beneath seals and gaskets, and other areas where fresh oxygenated electrolyte is excluded. The crevice in seawater will become enriched with chloride, the $\mathrm{pH}$ will decrease, and rapid attack will occur. The large surface areas adjacent to the crevice are cathodic and accelerate attack. Once it starts, crevice corrosion is difficult to arrest. It is one of the more troublesome forms of corrosion that exist in engineered structures $[20,22]$.

Biofouling organisms may be present in seawater. If they are able to attach themselves to metal, they will locally shield the metal surface from free electrolyte and may initiate crevice corrosion. Another type of crevice attack may be present when a metal is in contact with sediment [8]. The sediment will limit the availability of oxygenated seawater so that a "differential aeration cell" is formed. The non-aerated (sediment covered) side is anodic with respect to the adjacent surfaces not in contact with the sediment. Thus metal just beneath the sediment tends to have a faster corrosion rate.

\subsubsection{Galvanic Corrosion}

Galvanic corrosion occurs when two dissimilar metals are in electrical contact while immersed in an electrolyte. The potential difference between them will cause corrosion to occur on the less "noble" metal. The nobility of different metals in seawater proceeding from the least to the most noble metals are given in Table 2.1 from data taken from the literature [23-27]. Under galvanic corrosion conditions, some metals that have a tendency to corrode uniformly when exposed alone, may exhibit localized pitting and/or crevice corrosion. Other metals which would normally suffer localized attack may be protected by appropriate choice of a galvanic couple $[19,20,28]$. 
Table 2.1 Galvanic Series of Metals and Alloys in Seawater [23-27]

\begin{tabular}{|c|c|}
\hline Metal & Potential (Volts) [vs. S.C.E. $\left.{ }^{(1)}\right]$ \\
\hline Magnesium (Active end) & -1.60 to -1.63 \\
\hline Zinc & -1.03 \\
\hline Aluminum 3003-(H) & -0.79 \\
\hline Aluminum 6061-(T) & -0.76 \\
\hline Cadmium & -0.7 \\
\hline Cast Iron & -0.61 \\
\hline Carbon Steel & -0.61 \\
\hline Steels (structural and low alloy) & -0.57 to -0.70 \\
\hline Stainless Steel (active) Type $\mathbf{4 3 0}$ & -0.57 \\
\hline Type 304 & -0.53 \\
\hline Type 410 & -0.51 \\
\hline Al-Bronze D & -0.30 to -0.42 \\
\hline Naval Brass & -0.40 \\
\hline Tin & -0.42 \\
\hline Copper & -0.36 \\
\hline Red Brass & -0.33 \\
\hline Bronze, Composition $\mathrm{G}$ & -0.31 \\
\hline Admiralty Brass & -0.29 \\
\hline Manganese Bronze & -0.25 to -0.33 \\
\hline Silicon Bronze & -0.24 to -0.27 \\
\hline $90-10 \mathrm{Cu}-\mathrm{Ni}$ & -0.28 \\
\hline $70-30 \mathrm{Cu}-\mathrm{Ni}$ & -.025 \\
\hline Bronze, Composition M & -0.23 \\
\hline Stainless Steel (passive) Type 430 & -0.22 \\
\hline Nickel & -0.20 \\
\hline Lead & -0.19 to -0.25 \\
\hline Stainless Steel (passive) Type 410 & -0.15 \\
\hline Silver & -0.13 \\
\hline 17/4 pH Stainless Steel (passive) & -0.10 to -0.20 \\
\hline Stainless Steel (passive) Type 304 & -0.08 \\
\hline Type 316 & -0.05 \\
\hline Monel 400 & -0.04 to -0.20 \\
\hline Stainless Alloy $20 \mathrm{Cb} 3$ & +0.05 to -0.15 \\
\hline Titanium and Titanium Alloys & +0.06 to -0.05 \\
\hline Inconel 625 & +0.10 to -0.04 \\
\hline Hastelloy C-276 & +0.10 to -0.04 \\
\hline Tantalum & +0.20 \\
\hline (Noble end) & +0.35 to +0.20 \\
\hline
\end{tabular}

(1) Saturated calomel electrode. 


\subsubsection{Stress-Corrosion Cracking}

Stress-corrosion cracking is defined as the cracking of metals produced by the combined action of corrosion and a tensile stress [29]. The stresses may be "residual" meaning that they are introduced during barrier fabrication or welding, or they may be applied stresses that originate from the service environment such as hydrostatic pressures in the ocean.

\subsubsection{Intergranular Attack}

This type of localized attack occurs along the grain boundaries of some alloys, and may lead to deep penetration and barrier failure. Austenitic (gamma phase) stainless steels are prone to this form of attack if they contain greater than about $0.03 \%$ carbon and are subjected to prolonged heating (e.g. during welding) in the temperature range $425-900{ }^{\circ} \mathrm{C}$. Chromium carbide is precipitated at the grain boundaries leaving an adjacent region that is deficient in chromium. The material is said to be "sensitized" and certain aqueous environments, such as those containing chlorides and sulfates at high temperature may locally attack the grain boundaries where there is insufficient chromium to resist corrosion [30]. Under seawater conditions intergranular attack in carbon or low-alloy steels is unlikely, based on literature reviewed to date.

\subsubsection{Hydrogen Embrittlement}

Hydrogen embrittlement may occur if atomic hydrogen enters a metal [15]. In ferrous materials the mechanism of embrittlement is not fully understood but it appears to be connected with the migration of hydrogen to locations in the metal where it interferes with the plastic deformation process [15]. For zirconium and titanium, which have limited solubility for hydrogen at ambient temperatures, brittle hydrides are formed and they cause a loss in ductility [15]. Under the low temperature, intermediate $\mathrm{pH}$ conditions that exist in the ocean, the amount of hydrogen that is generated by expected corrosion mechanisms is probably too small to cause hydrogen embrittlement.

\subsubsection{De-zincification or De-(metal)-ification}

Brass, an alloy of copper and zinc, has been extensively used in marine environments. Under some conditions, however, it will suffer a preferential loss of zinc. One theory is that both the copper and zinc are lost at anodic regions but that the copper is redeposited. The net effect is a loss in the zinc component. Reinhart showed that many brasses and bronzes ( $\mathrm{Cu}-\mathrm{Sn})$ are susceptible to demetalification in the deep ocean [31].

\subsubsection{Filiform Corrosion}

This type of attack is characterized by "filaments" of corrosion products that lie at the interface between the metal and a paint or other applied protective coating [11]. The corrosion is made possible when the coating is porous to water and oxygen. It causes only superficial damage and has been observed in steel, zinc, magnesium, and aluminum [11]. 


\subsection{Corrosion of Carbon and Low-Alloy Steels}

Carbon and low-alloy steels have been widely used in marine service, mainly because of their cost effectiveness. Standard carbon steels contain up to about $1.0 \%$ carbon plus small amounts of manganese, phosphorus, and silicon. Low-carbon steels (less than $0.30 \% \mathrm{C}$ ) were often used in the past for waste containers because of their superior ductility. Low-alloy steels contain nickel, chromium, and molybdenum to give increased strength and superior corrosion resistance in some environments. For ocean disposal the containers were often used as the mold in which the wastes are mixed and solidified in cement, as well as the transportation and disposal container. The concept of ocean disposal was centered on containment of the radionuclides for a specified time period during which most of the radioactivity decayed to a low level. This was followed by a period of when the remaining radioactive material was slowly dispersed into the ocean through breaches in the container.

This report will focus mainly on reviewing the corrosion of carbon and low-alloy steels because they are the materials that have been traditionally used for ocean dumping in the past. Also, there exists a relatively large body of corrosion data for analysis. Smaller-scale experiments will be considered first, followed by results from waste containers that were corroded under actual or simulated ocean environments.

\subsubsection{Smaller-Scale Experiments}

\subsubsection{Uniform Corrosion and Pitting}

Larrabee carried out some of the earlier work on the corrosion of carbon and low-alloy steels in seawater $[32,33]$. In low-carbon (mild) steel tests lasting up to 7.5 years he showed that the uniform corrosion rate for nine locations around the U.S. and France averaged 5.2 mils $/ y(0.13 \mathrm{~mm} / \mathrm{y})$. Maximum pitting rates average $27 \mathrm{mils} / \mathrm{y}(0.69 \mathrm{~mm} / \mathrm{y})$.

Larrabee [33] compared the corrosion rate of carbon steel and low-alloy steels (compositions are given in Table 2.2). The results given in Table 2.3 show that most of the materials gave very similar uniform corrosion rates in tests lasting up to $4.5 \mathrm{y}$. The exception was Cr-Mo steel which had a corrosion rate of about one-third of those for the other steels. The corrosion rates for all of the steels decreased with increasing test time. Some data by Reinhart confirm that low-alloy steels show a major decrease in corrosion rate in tests lasting about three years [34]. From an initial rate of $7.9 \mathrm{mils} / \mathrm{y}(0.2 \mathrm{~mm} / \mathrm{y})$ the value fell to $3.2 \mathrm{mils} / \mathrm{y}(0.08$ $\mathrm{mm} / \mathrm{y}$ ) (Figure 2.1).

A significant factor in corrosion is the availability of oxygen in seawater. Unless oxygen is available, cathodic depolarization cannot occur and corrosion will normally cease. Experiments carried out near the ocean surface, where oxygen is relatively plentiful, and temperatures higher than in the deep ocean, will give corrosion rates that do not accurately reflect ocean disposal site conditions. Figures 2.2 and 2.3 show the strong correlation between the amount of dissolved oxygen and the sea water corrosion of low-alloy steels [31]. For ocean depths between 500-2000 m the uniform corrosion rates are about $2 \mathrm{mils} / \mathrm{y}(0.05 \mathrm{~mm} / \mathrm{y})$. At shallow depths the rates are in the general range of 3-7 mils/y $(0.08-0.18 \mathrm{~mm} / \mathrm{y})$. 
Table 2.2 Steel Compositions - Percent [33]

\begin{tabular}{|l|c|c|c|c|c|c|c|c|c|}
\hline \multicolumn{1}{|c|}{ Steel } & $\mathrm{C}$ & $\mathrm{Mn}$ & $\mathrm{P}$ & $\mathrm{S}$ & $\mathrm{Si}$ & $\mathrm{Cu}$ & $\mathrm{Ni}$ & $\mathrm{Cr}$ & $\mathrm{Mo}$ \\
\hline \hline $\begin{array}{l}\text { Cor-Ten } \\
\text { Brand }\end{array}$ & 0.08 & 0.36 & 0.08 & 0.026 & 0.31 & 0.41 & 0.49 & 0.73 & -- \\
\hline Tri-Ten Brand & 0.17 & 1.2 & 0.026 & 0.025 & 0.18 & 0.31 & 0.53 & 0.07 & -- \\
\hline $\mathrm{Ni}-\mathrm{Cu}$ & 0.19 & 0.44 & 0.030 & 0.032 & 0.025 & 0.81 & 1.8 & 0.22 & -- \\
\hline Cr-Mo & 0.07 & 0.39 & 0.014 & 0.020 & 0.09 & 0.020 & 0.04 & 2.6 & 0.52 \\
\hline $\begin{array}{l}\text { Structural } \\
\text { Carbon }\end{array}$ & 0.25 & 0.42 & 0.020 & 0.032 & 0.025 & 0.012 & 0.02 & 0.06 & -- \\
\hline
\end{tabular}

Table 2.3 Corrosion Rates of Steels in Sea Water [33]

\begin{tabular}{|l|c|c|c|}
\hline \multirow{2}{*}{ Steel } & \multicolumn{3}{|c|}{ Average Penetration, Mils per Year - Each Surface } \\
\cline { 2 - 4 } & \multicolumn{3}{|c|}{ Years Exposure } \\
\cline { 2 - 4 } & 1.5 & 2.5 & 4.5 \\
\hline \hline Cor-Ten Brand & 4.2 & 4.3 & 3.8 \\
\hline Tri-Ten Brand & 4.4 & 3.8 & 3.0 \\
\hline Ni-Cu & 5.3 & 4.5 & 3.5 \\
\hline Cr-Mo & 1.4 & 1.6 & 1.6 \\
\hline Structural Carbon & 4.8 & 4.1 & 3.3 \\
\hline
\end{tabular}




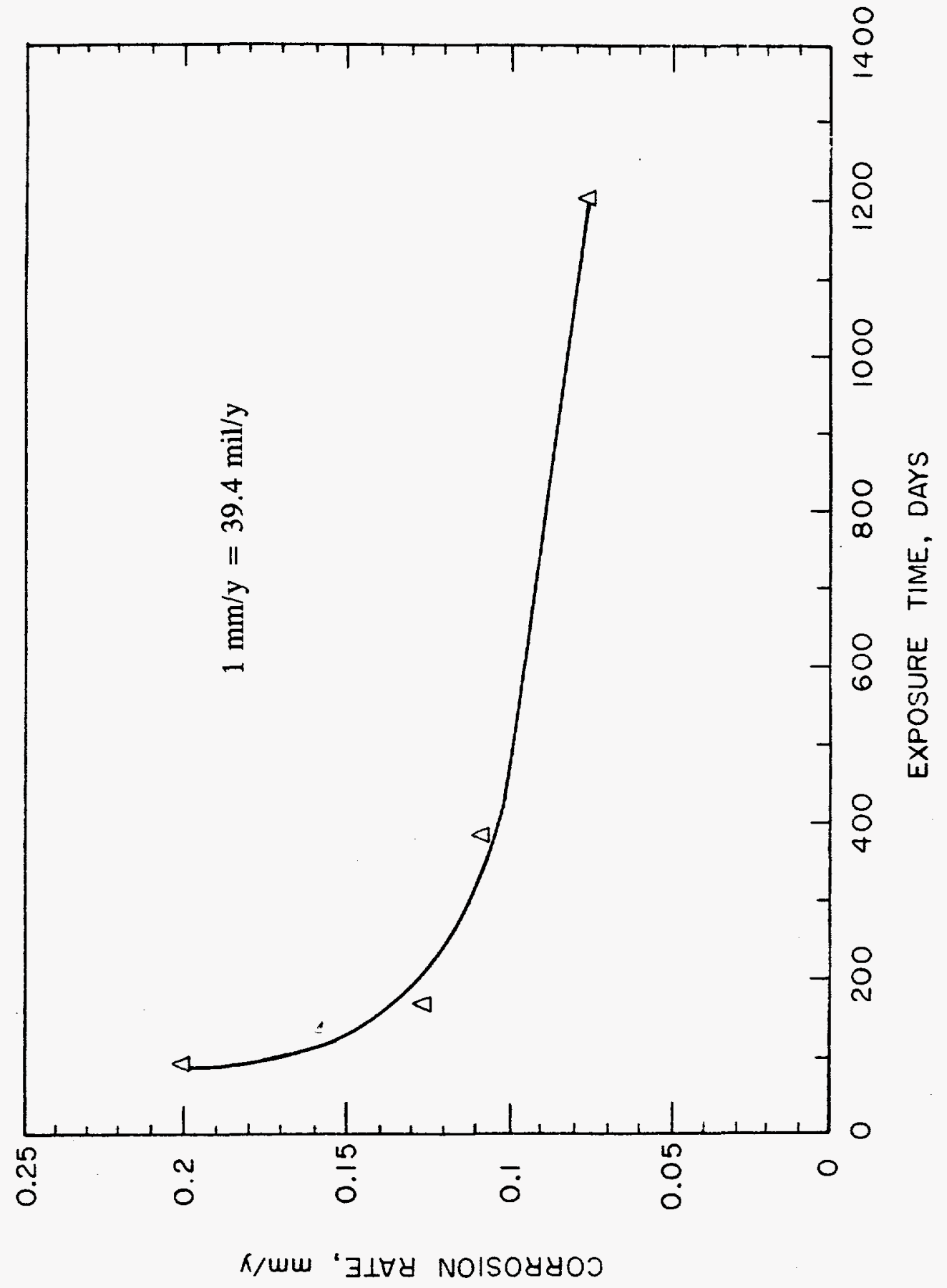

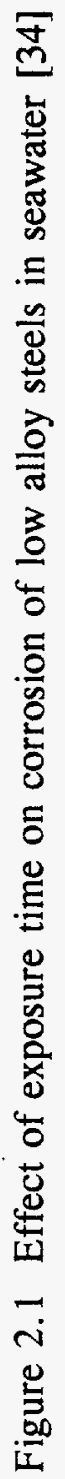




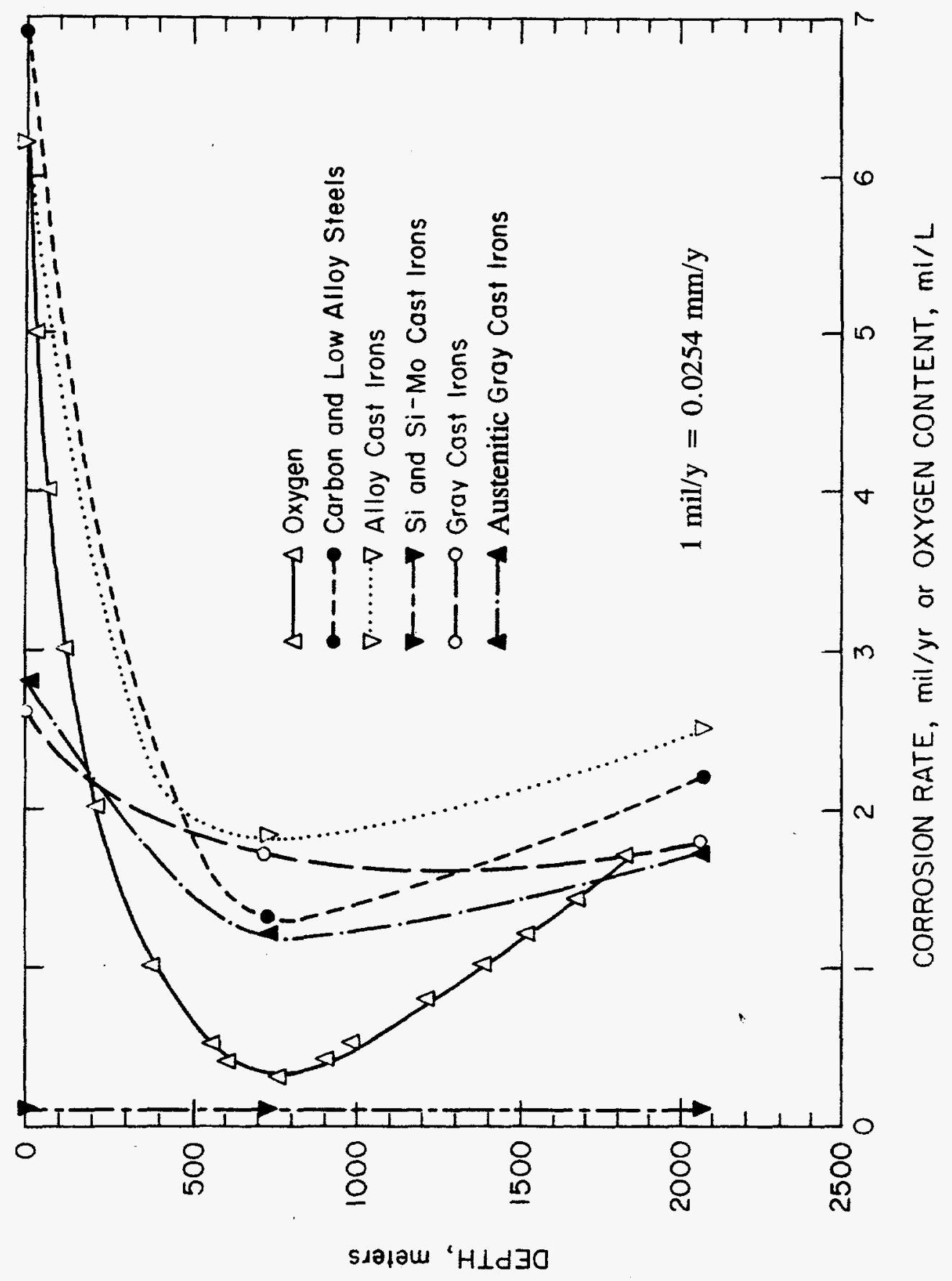

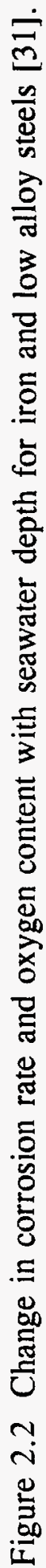




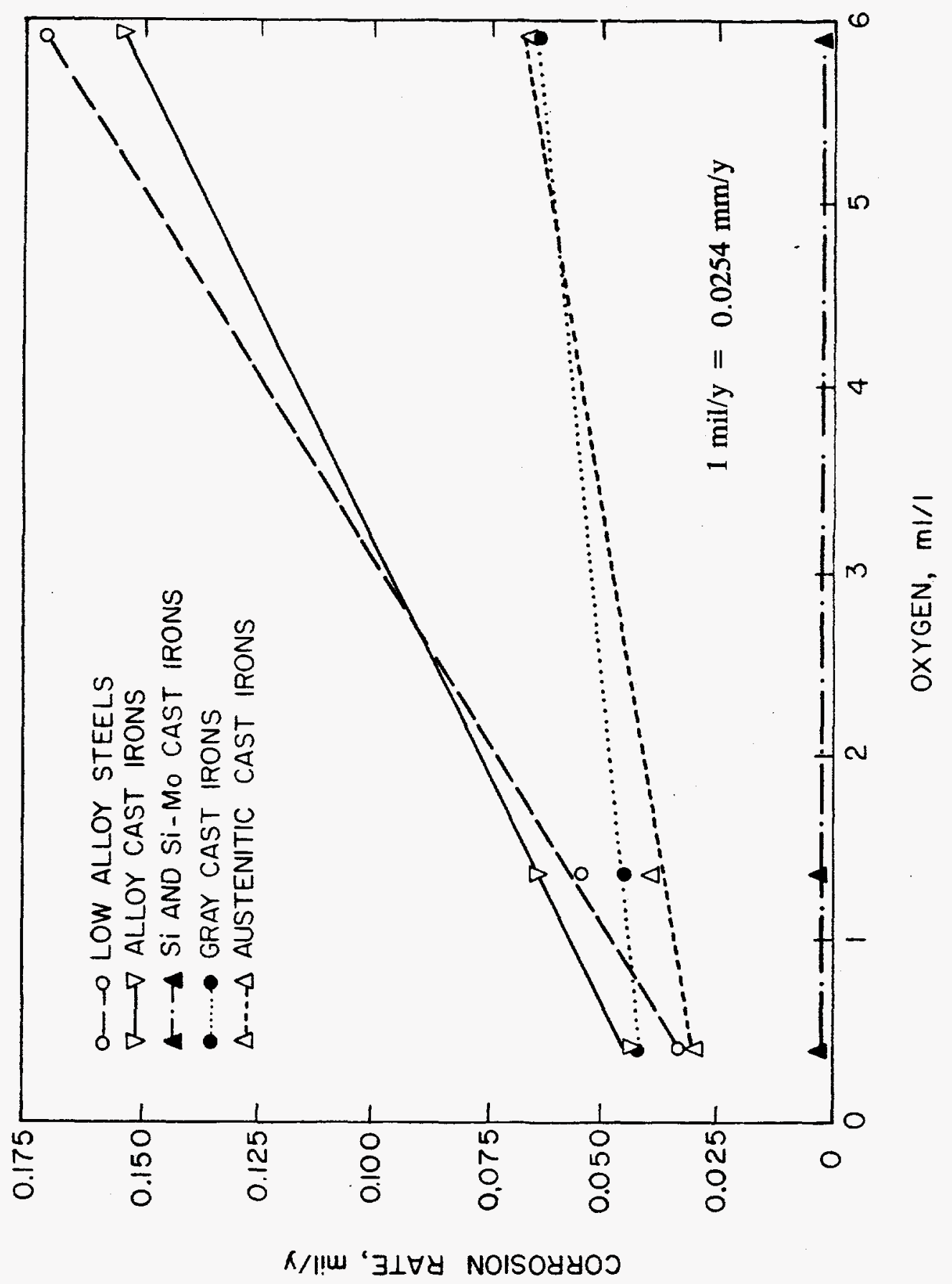

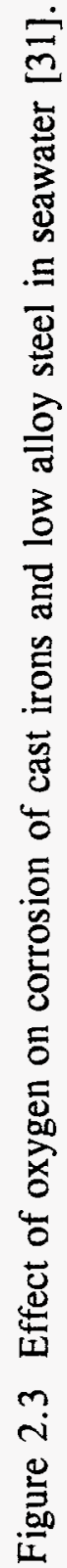


An important study by Suss and co-workers evaluated the corrosion of carbon steel, lowalloy steel, austenitic stainless steel, and Inconel-600 in deep 3000-3700 m locations in the Northwestern Atlantic Ocean [35]. Figure 2.4 is one of three test rigs used. This one allowed the study of samples exposed to flowing seawater as well as specimens in sediment. Two different corrosion sites were selected (Figure 2.5). Table 2.4 gives the deployment and recovery dates for the samples and the general corrosion environments. The seawater oxygen levels were between 6.5 to $7.5 \mathrm{mg} / \mathrm{L}$, the water flow rate was $5-10 \mathrm{~cm} / \mathrm{sec}$, and the temperature was 2.6 to $3.0^{\circ} \mathrm{C}$. The upper layers of sediment were stated to be well oxygenated.

Suss' data for carbon and low-alloy steels are given in Table 2.5. They show that corrosion rates increase with seawater flow rate from stagnant to free flow. The data for samples immersed in sediments were more variable, possibly because of local differences in the sediment environments. The maximum corrosion rate for carbon steel considering all conditions was $12.7 \mathrm{mils} / \mathrm{y}(0.32 \mathrm{~mm} / \mathrm{y})$. From an analysis of all of the results for carbon steels Suss showed that the steady state corrosion rates were $1 \mathrm{mil} / \mathrm{y}(0.03 \mathrm{~mm} / \mathrm{y})$ in low seawater flow conditions, $2.7 \mathrm{mils} / \mathrm{y}(0.07 \mathrm{~mm} / \mathrm{y})$ in normal flow conditions, and from 2.2-6.4 mils/y (0.06$0.16 \mathrm{~mm} / \mathrm{y}$ ) in the sediment - see Table 2.6 . The low-alloy steel generally corroded at one-half the rate of the carbon steel.

This study was continued, and new longer-term corrosion data were published by Barth and Sheldon [36]. They confirmed that carbon steel corroded more quickly than alloy steels and that flowing seawater usually gave the faster rates of corrosion. The follow-on study again showed that corrosion of carbon and low alloy steels could be high for sediment environments. In fact, these longer-term results showed that the rates in flowing seawater and sediments are approximately equal.

Other data reviews generally confirm the above corrosion rates [10-15,37].

Figure 2.6 shows a plot of some of the available data on the very long-term uniform corrosion of carbon and low-alloys steels $[31,33,38]$. After an initial period of about 1-2 y the corrosion rate becomes constant at about $5 \mathrm{mils} / \mathrm{y}(0.13 \mathrm{~mm} / \mathrm{y})$. As mentioned above, seawater $\mathrm{pH}$ also affects the corrosion rate. Figure 2.7 shows that within the $\mathrm{pH}$ range 5-9 the corrosion rate for iron and low-alloy steel remains constant $[39,40]$. It is only under highly acidic conditions that fast corrosion is initiated.

Seawater velocity also has a significant effect on the corrosion rate of steels (see Figure 2.8) [41]. However, the slow water movement in a deep disposal site will be beneficial compared to the near surface where ocean currents are faster.

\subsubsection{Galvanic Corrosion}

Suss also studied the seawater galvanic corrosion of carbon steel in contact with type 308 stainless steel weld metal [35]. As expected, the more anodic carbon steel corrodes significantly faster than carbon steel alone (compare Tables 2.5 and 2.6). If dissimilar metals or alloys are in contact with each other at an ocean disposal site, the galvanic series given in Table 2.1 gives guidance on which of the metals or alloys will suffer accelerated attack. A continuation of this study confirmed the validity of the earlier data [36]. 


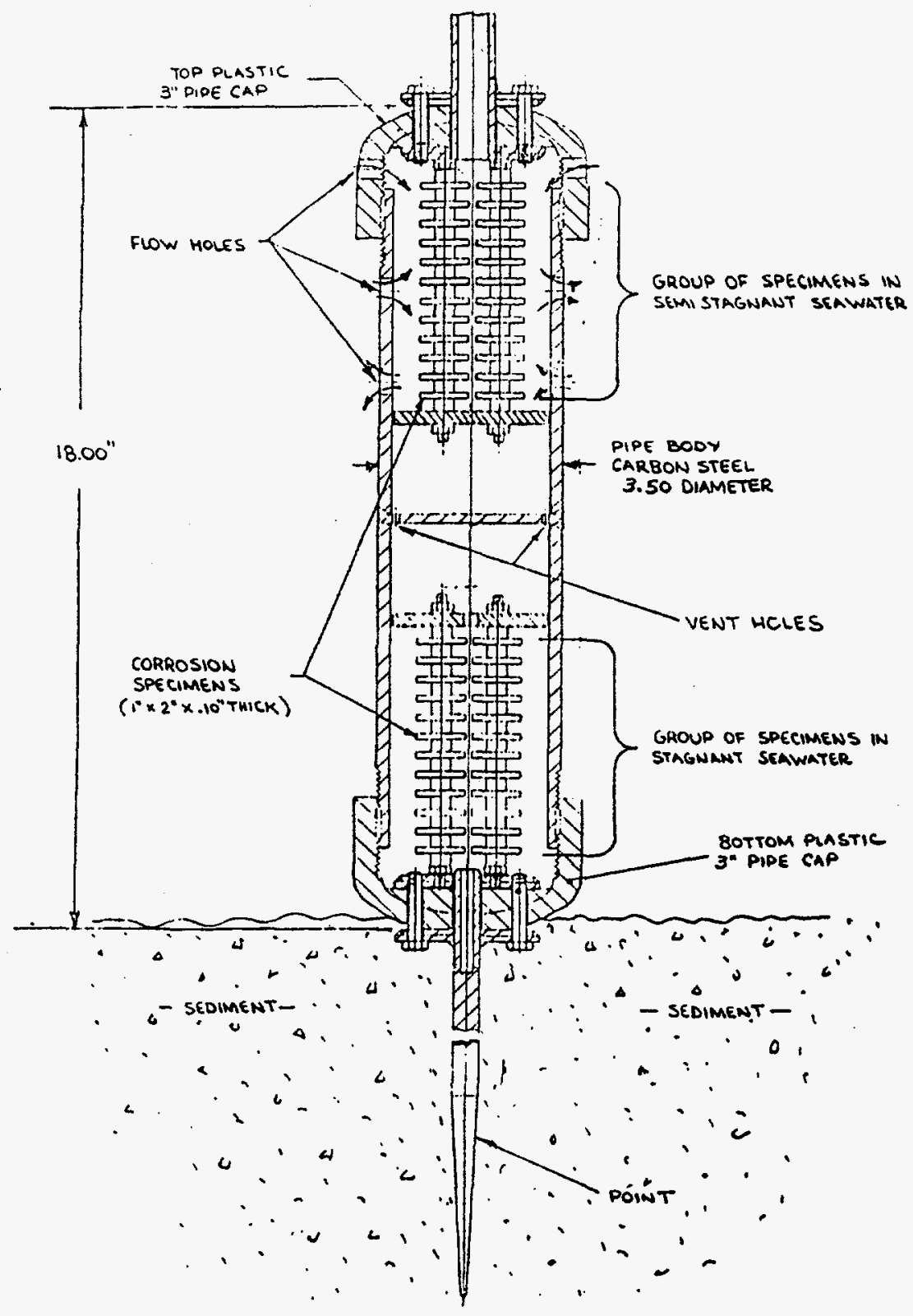

Figure 2.4 Type 3 corrosion specimen assembly [35]. 


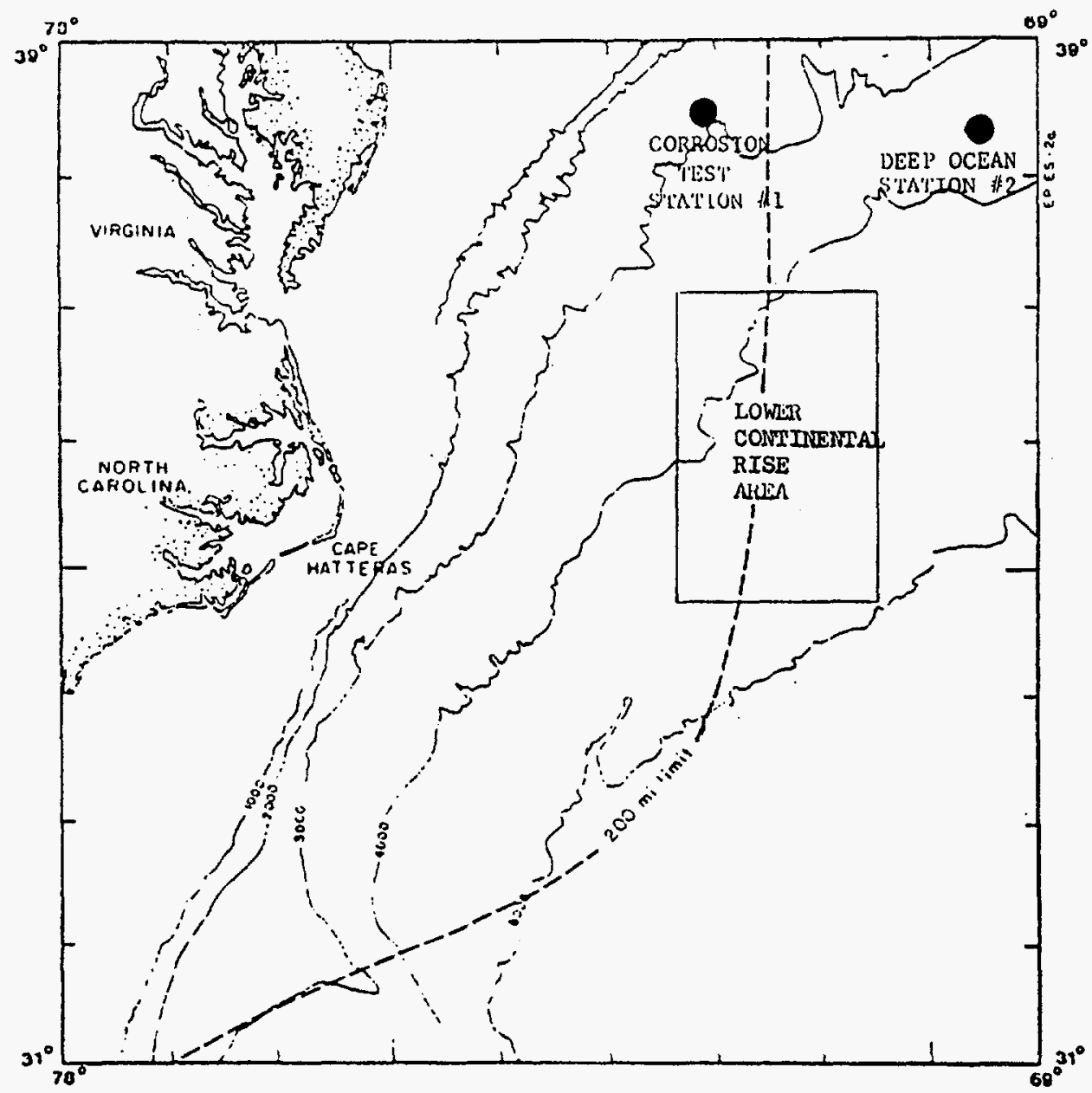

Figure 2.5 Atlantic Ocean study locations [35]. 
Table 2.4 Deployment and Recovery of Corrosion Experiments [35]

\begin{tabular}{|l|c|c|c|c|}
\hline \multicolumn{1}{|c|}{ Location } & $\begin{array}{c}\text { Type } \\
\text { Corrosion } \\
\text { Unit }\end{array}$ & Environment(s) & $\begin{array}{c}\text { Deployment } \\
\text { Date }\end{array}$ & $\begin{array}{c}\text { Recovery } \\
\text { Date }\end{array}$ \\
\hline $\begin{array}{l}\text { Corrosion Test Station } \\
\text { Number One (CTS-1) } \\
\text { (3000 in depth) }\end{array}$ & 1 & Flowing seawater & July 1977 & July 1979 \\
\hline $\begin{array}{l}\text { Woods Hole } \\
\text { Institution Deep } \\
\text { Ocean Station Number } \\
\text { Two (DOS-2) }\end{array}$ & 2 & $\begin{array}{c}\text { Flowing seawater } \\
\text { Flowing seawater } \\
\text { and sediment }\end{array}$ & July 1977 & July 1980 \\
(3700 in depth) & 2 & $\begin{array}{c}\text { Flowing seawater } \\
\text { and sediment } \\
\text { Flowing seawater } \\
\text { and sediment } \\
\text { Flowing seawater } \\
\text { and sediment } \\
\text { Stagnant and } \\
\text { semistagnant } \\
\text { seawater } \\
\text { Stagnant and } \\
\text { semistagnant } \\
\text { seawater }\end{array}$ & July 1979 & July 1980 \\
& 3 & July 1979 & July 1980 \\
\hline
\end{tabular}


Table 2.5 Corrosion Rates (Mils/Year) ${ }^{(a)}$ of

ASTM A516 Carbon Steel and Hy-80 Low Alloy Steel ${ }^{(b)}$ [35]

\begin{tabular}{|c|c|c|c|c|c|c|}
\hline \multirow[b]{2}{*}{ Environment } & \multirow[b]{2}{*}{ Station } & \multirow{2}{*}{$\begin{array}{l}\text { Exposure } \\
\text { Duration } \\
\text { Years }\end{array}$} & \multicolumn{2}{|c|}{ ASTM A516 Carbon Steel } & \multicolumn{2}{|c|}{ Hy-80 Low Alloy Steel } \\
\hline & & & Mean \pm S.D. & Range & Mean \pm S.D. & Range \\
\hline $\begin{array}{l}\text { Flowing } \\
\text { seawater }\end{array}$ & $\begin{array}{l}\text { DOS-2 } \\
\text { DOS-2 } \\
\text { CTS-1 } \\
\text { CTS-1 } \\
\text { CTS-1 } \\
\text { DOS-2 }\end{array}$ & $\begin{array}{l}0.8 \\
1.0 \\
1.0 \\
2.0 \\
3.0 \\
3.1\end{array}$ & $\begin{array}{l}3.14 \pm 0.27 \\
3.30 \pm 0.11 \\
2.99 \pm 0.29 \\
1.64 \\
2.07 \\
3.17 \text { (h) }\end{array}$ & $\begin{array}{l}2.75-3.33 \\
3.19-3.45 \\
2.72-3.30 \\
-- \\
-- \\
1.78-6.38\end{array}$ & $\begin{array}{l}2.60 \pm 0.20 \\
2.68 \pm 0.19 \\
2.49 \pm 0.56 \\
1.13 \\
1.27 \\
1.09 \pm 0.07\end{array}$ & $\begin{array}{l}2.45-2.89 \\
2.50-2.87 \\
2.14-3.33 \\
-- \\
-- \\
1.00-1.15\end{array}$ \\
\hline $\begin{array}{l}\text { Semistagnant } \\
\text { seawater }\end{array}$ & $\begin{array}{l}\text { DOS-2 } \\
\text { DOS-2 }\end{array}$ & $\begin{array}{l}1.0 \\
3.1\end{array}$ & $\begin{array}{l}1.65 \pm 0.35 \\
0.64 \pm 0.13\end{array}$ & $\begin{array}{l}1.34-2.03 \\
0.51-0.77\end{array}$ & $\begin{array}{l}0.99 \pm 0.06 \\
0.45 \pm 0.08\end{array}$ & $\begin{array}{l}0.90-1.04 \\
0.36-0.52\end{array}$ \\
\hline $\begin{array}{l}\text { Stagnant } \\
\text { seawater }\end{array}$ & $\begin{array}{l}\text { DOS-2 } \\
\text { DOS-2 }\end{array}$ & $\begin{array}{l}1.0 \\
3.1\end{array}$ & $\begin{array}{l}0.22 \pm 0.02 \\
0.038 \pm 0.005(f)\end{array}$ & $\begin{array}{l}0.20-0.25 \\
0.035-0.044\end{array}$ & $\begin{array}{l}0.17 \pm 0.02 \\
0.017 \\
\pm 0.009(\mathrm{~g})\end{array}$ & $\begin{array}{l}0.15-0.19 \\
0.010-0.024\end{array}$ \\
\hline Sediment & $\begin{array}{l}\text { DOS-2 } \\
\text { DOS-2 } \\
\text { CTS-1(c) } \\
\text { DOS-2 }\end{array}$ & $\begin{array}{l}0.8 \\
1.0 \\
1.0 \\
3.1\end{array}$ & $\begin{array}{l}0.29 \pm 0.06 \\
1.30(\mathrm{~h}) \\
5.37(\mathrm{~h}) \\
\text { (d),(i) }\end{array}$ & $\begin{array}{l}0.21-0.36 \\
0.16-2.42 \\
2.71-12.7 \\
2.23-6.40\end{array}$ & $\begin{array}{l}0.19 \pm 0.06 \\
0.82(\mathrm{~h}) \\
2.81 \pm 0.41 \\
(\mathrm{e}),(\mathrm{i})\end{array}$ & $\begin{array}{l}0.15-0.28 \\
0.16-2.62 \\
2.22-3.17 \\
0.46-6.42\end{array}$ \\
\hline
\end{tabular}

Notes:

a. $1 \mathrm{mil} / \mathrm{y}=0.0254 \mathrm{~mm} / \mathrm{y}$

b. Corrosion rates are mean values and ranges of four specimen \pm standard deviation unless otherwise indicated. No standard deviation or range indicates value either not calculated or obtained from one specimen only.

c. Corrosion test frame assembly was found tipped over on top of sediment and not completely buried as originally deployed.

d. Two of four specimens completely oxidized.

e. One of four specimens completely oxidized.

f. Value based on three specimens.

g. Value based on two specimens.

h. Standard deviations were not calculated for these samples because the data did not reflect a normal distribution.

i. Means and standard deviations were not calculated for these samples because the data did not reflect a normal distribution. 
Table 2.6 Corrosion Rates (Mils/Year) ${ }^{(a)}$ of ASTM A516 Carbon Steel in Contact with Stainless Steel (CRES 308) ${ }^{(\mathrm{b})}$ [35]

\begin{tabular}{|c|c|c|c|c|}
\hline \multirow[b]{2}{*}{ Environment } & \multicolumn{4}{|c|}{$\begin{array}{l}\text { Exposure } \\
\text { Duration }\end{array}$} \\
\hline & Station & Years & Mean \pm S.D. & Range \\
\hline Flowing seawater & $\begin{array}{l}\text { DOS-2 } \\
\text { DOS-2 } \\
\text { CTS-1 } \\
\text { CTS-1 } \\
\text { CTS-1 } \\
\text { DOS-2 }\end{array}$ & $\begin{array}{l}0.8 \\
1.0 \\
1.0 \\
2.0 \\
3.0 \\
3.1\end{array}$ & $\begin{array}{l}10.1 \pm 0.64 \\
6.63 \pm 0.61 \\
5.67 \pm 0.93 \\
18.4 \\
15.3 \\
4.28 \pm 0.29\end{array}$ & $\begin{array}{l}9.33-10.9 \\
6.09-7.36 \\
4.84-6.93 \\
-- \\
-- \\
3.97-4.66\end{array}$ \\
\hline $\begin{array}{l}\text { Semistagnant } \\
\text { seawater }\end{array}$ & $\begin{array}{l}\text { DOS-2 } \\
\text { DOS-2 }\end{array}$ & $\begin{array}{l}1.0 \\
3.1\end{array}$ & $\begin{array}{l}2.19 \pm 0.18 \\
0.93 \pm 0.21\end{array}$ & $\begin{array}{l}2.02-2.38 \\
0.73-1.09\end{array}$ \\
\hline Stagnant seawater & $\begin{array}{l}\text { DOS-2 } \\
\text { DOS-2 }\end{array}$ & $\begin{array}{l}1.0 \\
3.1\end{array}$ & $\begin{array}{l}0.28 \pm 0.02 \\
0.035 \pm 0.005(\mathrm{~d})\end{array}$ & $\begin{array}{l}0.26-0.30 \\
0.030-0.037(\mathrm{c})\end{array}$ \\
\hline Sediment & $\begin{array}{l}\text { DOS-2 } \\
\text { DOS-2 } \\
\text { CTS-1(c) } \\
\text { DOS-2 }\end{array}$ & $\begin{array}{l}0.8 \\
1.0 \\
1.0 \\
3.1\end{array}$ & $\begin{array}{l}1.41(\mathrm{e}) \\
11.8(\mathrm{e}) \\
10.4(\mathrm{e}) \\
>16.2(\mathrm{e}),(\mathrm{f})\end{array}$ & $\begin{array}{l}0.37-2.47 \\
2.30-31.6 \\
4.93-25.4 \\
>16.2(\mathrm{e}),(\mathrm{f})\end{array}$ \\
\hline
\end{tabular}

Notes:

a. $1 \mathrm{mil} / \mathrm{y}=0.0254 \mathrm{~mm} / \mathrm{y}$

b. Corrosion rates are mean values and ranges of four specimen \pm standard deviation unless otherwise indicated. No standard deviation or range indicates value either not calculated or obtained from one specimen only.

c. Corrosion test frame assembly was found tipped over on top of sediment and not completely buried as originally deployed.

d. Value based on two specimens.

e. Standard deviations were not calculated for these samples because the data did not reflect a normal distribution.

f. The carbon steel portions of all four specimens completely oxidized. 


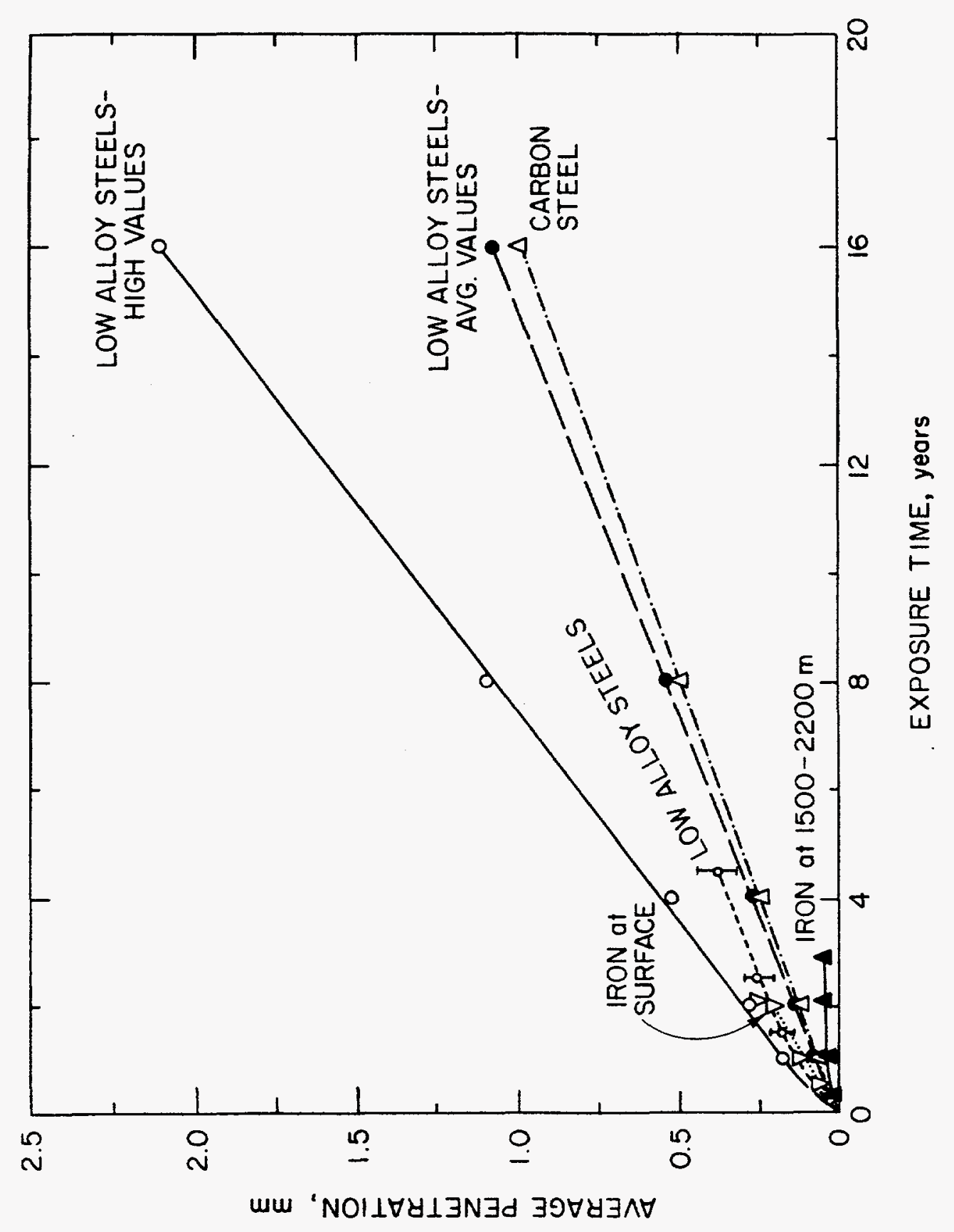

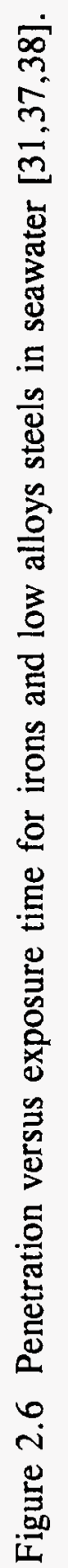




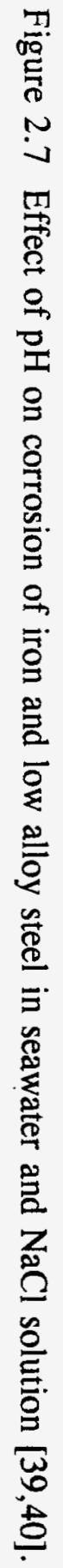

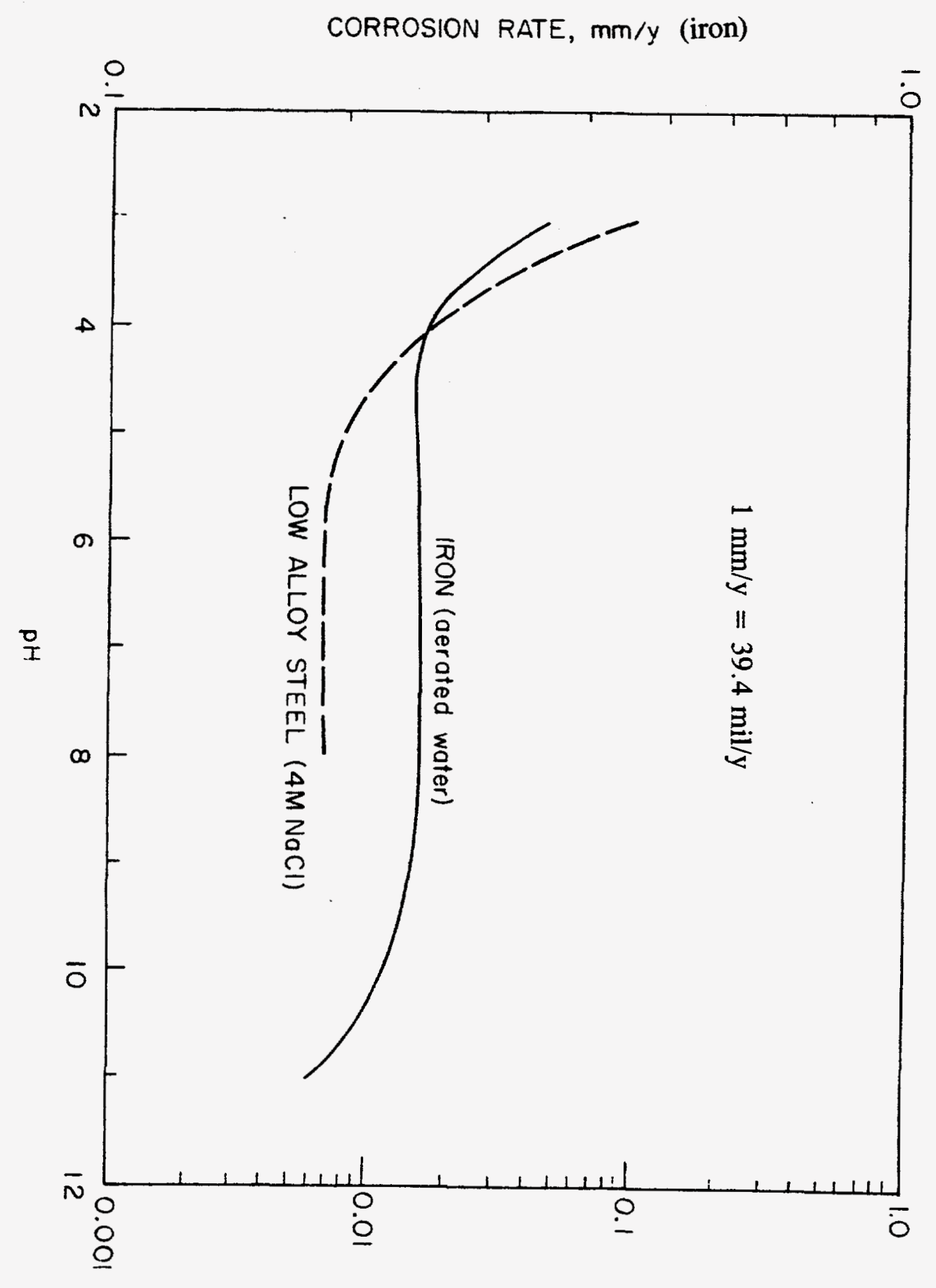

Corrosion Rate, $\mathrm{mm} / \mathrm{y}$

(low alloy steel) 


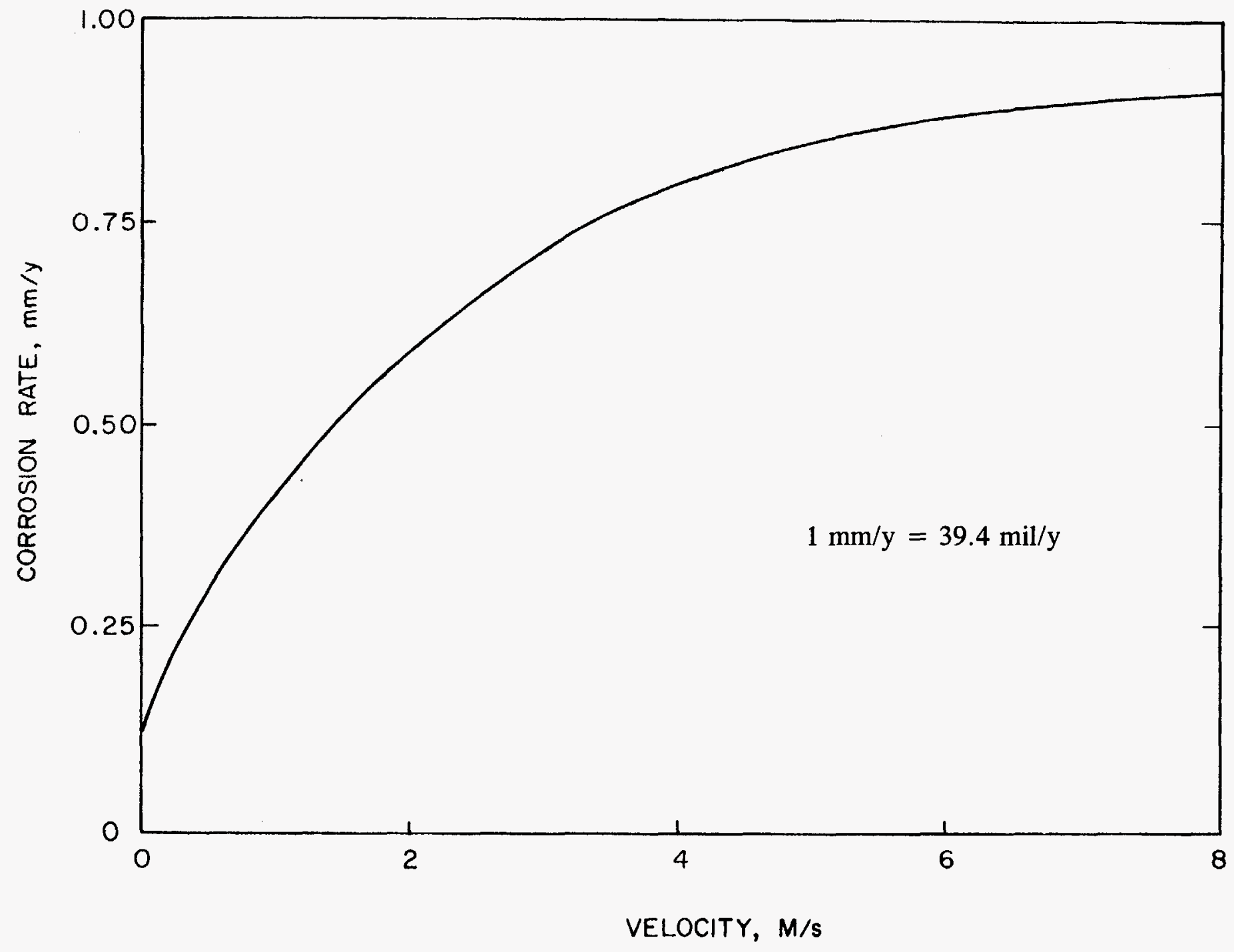

Figure 2.8 Effect of seawater velocity on corrosion of low alloy steels [41]. 


\subsubsection{Stress-Corrosion Cracking and Intergranular Corrosion}

As mentioned in Section 2.1.5, above, stress-corrosion cracking tends to occur only in materials that have strong passivation characteristics. (Carbon steel is not in this category). Breaches in the passive surface expose underlying free metal that is anodic, and fast crack propagation can occur in the presence of a tensile stress. Schmitt and Phelps exposed a range of low-alloy steels in quiescent sea water off Harbor Island N.C. at stress levels of $75 \%$ of the yield stress [42]. No failures were detected even in tests lasting for $6 \mathrm{y}$. In the current literature review there were no documented observations of stress-corrosion cracking of carbon or low-alloy steels in seawater.

A review of the literature for carbon and low-alloy steels, also, has not revealed any evidence for intergranular attack in seawater. Most likely, the relatively fast uniform corrosion rate provide a layer of corrosion products that prevent this type of localized attack.

\subsubsection{Full-Scale Tests}

A comprehensive program was carried out by the Japanese between the years 1977 and 1984 on the seawater corrosion of low-level waste drums made from carbon steel and stainless steel [43]. Full size 55 gallon (200L) containers filled with simulated cement wastes were tested in large tanks containing flowing seawater. Two test temperatures were used $\left(6.7\right.$ and $\left.23^{\circ} \mathrm{C}\right)$. The flow rate was about $2 \mathrm{~cm} / \mathrm{sec}$, the dissolved oxygen level was about $8 \mathrm{ppm}$ and the $\mathrm{pH}$ was between 7 and 8 . Figure 2.9 and Tables 2.7 and 2.8 show the results of seawater corrosion on uncoated carbon steel. Both average and localized (faster) corrosion were measured. The average corrosion rates in Figure 2.9 decrease with time with corrosion at $6.7^{\circ} \mathrm{C}$ decreasing to $0.8 \mathrm{mils} / \mathrm{y}(0.02 \mathrm{~mm} / \mathrm{y})$ after two years.

From 1946 to 1970 the U.S. used several Atlantic and Pacific Ocean sites for the disposal of low-level wastes. Brookhaven National Laboratory, under the sponsorship of the U.S. Environmental Protection Agency, performed an analysis of selected carbon steel containers filled with wastes that were retrieved from deep ocean sites $[2,3,4]$. Two of the sites are off the coast of Maryland at depths of 2800 and $3800 \mathrm{~m}$ (see Figure 2.10). A third site for container retrieval is in the Pacific off the Farallon Islands at a depth of $900 \mathrm{~m}$ (see Figure 2.11). Table 2.9 gives some of the environmental characteristics of the various sites [4].

\section{Meter Atlantic Site [2]}

In 1976, an 80 gallon $(290 \mathrm{~L})$ container filled with cementitious waste was retrieved. It was fabricated by welding together two sections from 55 gallon $(200 \mathrm{~L})$ drums because of the large size of another waste container enclosing cobalt-60 wastes that had to be placed within. The wall thickness of the container was 0.25 in. $(0.64 \mathrm{~cm}$.). The container had been on the ocean bed for about 15 years, lying in a generally horizontal position and partly buried in sediment. 


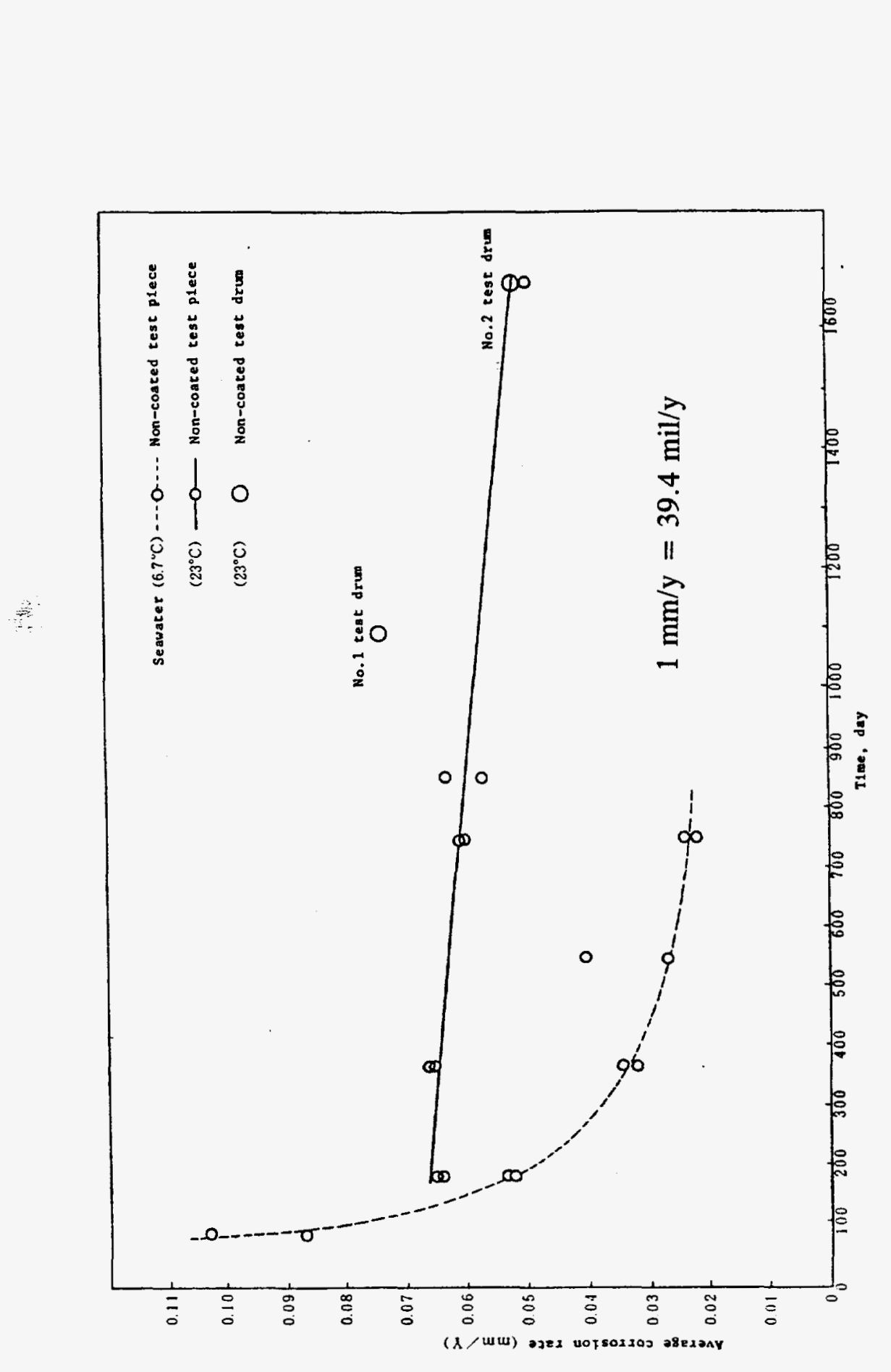

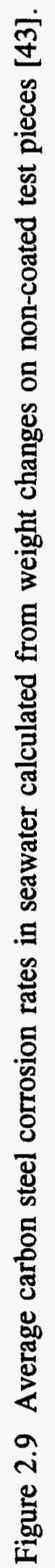


Table 2.7 Corrosion Amounts, Corrosion Depth and Average Corrosion Rates for Seawater Calculated from Weight Changes of Non-Coated Carbon Steel Test Pieces.

\begin{tabular}{|l|c|c|c|c|c|c|}
\hline \multirow{2}{*}{$\begin{array}{c}\text { Time } \\
(\text { day) }\end{array}$} & \multicolumn{2}{|c|}{$\begin{array}{c}\text { Corrosion amounts } \\
\left(\mathrm{mg} / \mathrm{cm}^{2}\right)\end{array}$} & \multicolumn{2}{c|}{$\begin{array}{c}\text { Corrosion depth } \\
(\mathrm{mm})\end{array}$} & \multicolumn{2}{c|}{$\begin{array}{c}\text { Average corrosion rate } \\
(\mathrm{mm} / \mathrm{y})\end{array}$} \\
\cline { 2 - 7 } & $6.7^{\circ} \mathrm{C}$ & $23^{\circ} \mathrm{C}$ & $6.7^{\circ} \mathrm{C}$ & $23^{\circ} \mathrm{C}$ & $6.7^{\circ} \mathrm{C}$ & $23^{\circ} \mathrm{C}$ \\
\hline \hline 90 & 18.33 & -- & 0.023 & -- & 0.095 & -- \\
\hline $182(187)$ & 20.55 & 26.05 & 0.026 & 0.033 & 0.053 & 0.065 \\
\hline 365 & 25.98 & 51.67 & 0.033 & 0.066 & 0.033 & 0.066 \\
\hline 549 & 39.78 & -- & 0.051 & -- & 0.034 & -- \\
\hline $748(730)$ & 36.82 & 95.32 & 0.047 & 0.121 & 0.023 & 0.061 \\
\hline 849 & -- & 109.37 & -- & 0.139 & -- & 0.060 \\
\hline 1679 & -- & 178.32 & -- & 0.227 & -- & 0.050 \\
\hline
\end{tabular}

- The time is the value at $23^{\circ} \mathrm{C}$.

* The average value for two test pieces except for values for 1679 days for which one test piece was used.

Table 2.8 Local Thickness Change and Local Corrosion Rates for Non-Coated Carbon Steel Test Pieces.

\begin{tabular}{|l|c|c|c|c|c|c|c|c|}
\hline \multirow{2}{*}{$\begin{array}{l}\text { Time } \\
(\text { day) }\end{array}$} & \multicolumn{2}{|c|}{$\begin{array}{c}\text { Thickness } \\
\text { before testing } \\
(\mathrm{mm})\end{array}$} & \multicolumn{2}{c|}{$\begin{array}{c}\text { Minimum } \\
\text { thickness after } \\
\text { testing** }(\mathrm{mm})\end{array}$} & \multicolumn{2}{c|}{$\begin{array}{c}\text { Maximum } \\
\text { thickness change } \\
(\mathrm{mm})\end{array}$} & \multicolumn{2}{|c|}{$\begin{array}{c}\text { Local } \\
\text { corrosion rate } \\
(\mathrm{mm} / \mathrm{y})\end{array}$} \\
\cline { 2 - 9 } & $6.7^{\circ} \mathrm{C}$ & $23^{\circ} \mathrm{C}$ & $6.7^{\circ} \mathrm{C}$ & $23^{\circ} \mathrm{C}$ & $6.7^{\circ} \mathrm{C}$ & $23^{\circ} \mathrm{C}$ & $6.7^{\circ} \mathrm{C}$ & $23^{\circ} \mathrm{C}$ \\
\hline 90 & 1.494 & -- & 1.367 & -- & 0.127 & -- & 0.26 & -- \\
\hline $182\left(187^{*}\right)$ & 1.488 & 1.487 & 1.324 & 1.314 & 0.164 & 0.173 & 0.16 & 0.17 \\
\hline 365 & 1.489 & 1.487 & 1.134 & 0.994 & 0.355 & 0.493 & 0.18 & 0.25 \\
\hline 549 & 1.492 & -- & 1.059 & -- & 0.433 & -- & 0.14 & -- \\
\hline $748\left(730^{*}\right)$ & 1.483 & 1.492 & 1.020 & 0.710 & 0.463 & 0.782 & 0.11 & 0.20 \\
\hline 847 & -- & 1.480 & -- & 0.515 & -- & 0.965 & -- & 0.21 \\
\hline 1679 & -- & 1.912 & -- & 0.368 & -- & 1.544 & -- & 0.17 \\
\hline
\end{tabular}

* The time is the value at $23^{\circ} \mathrm{C}$.

** The average value for the three paints in which thickness change was largest. The values for 1679 days were obtained by using one test piece, other ones were the average of two test pieces. 


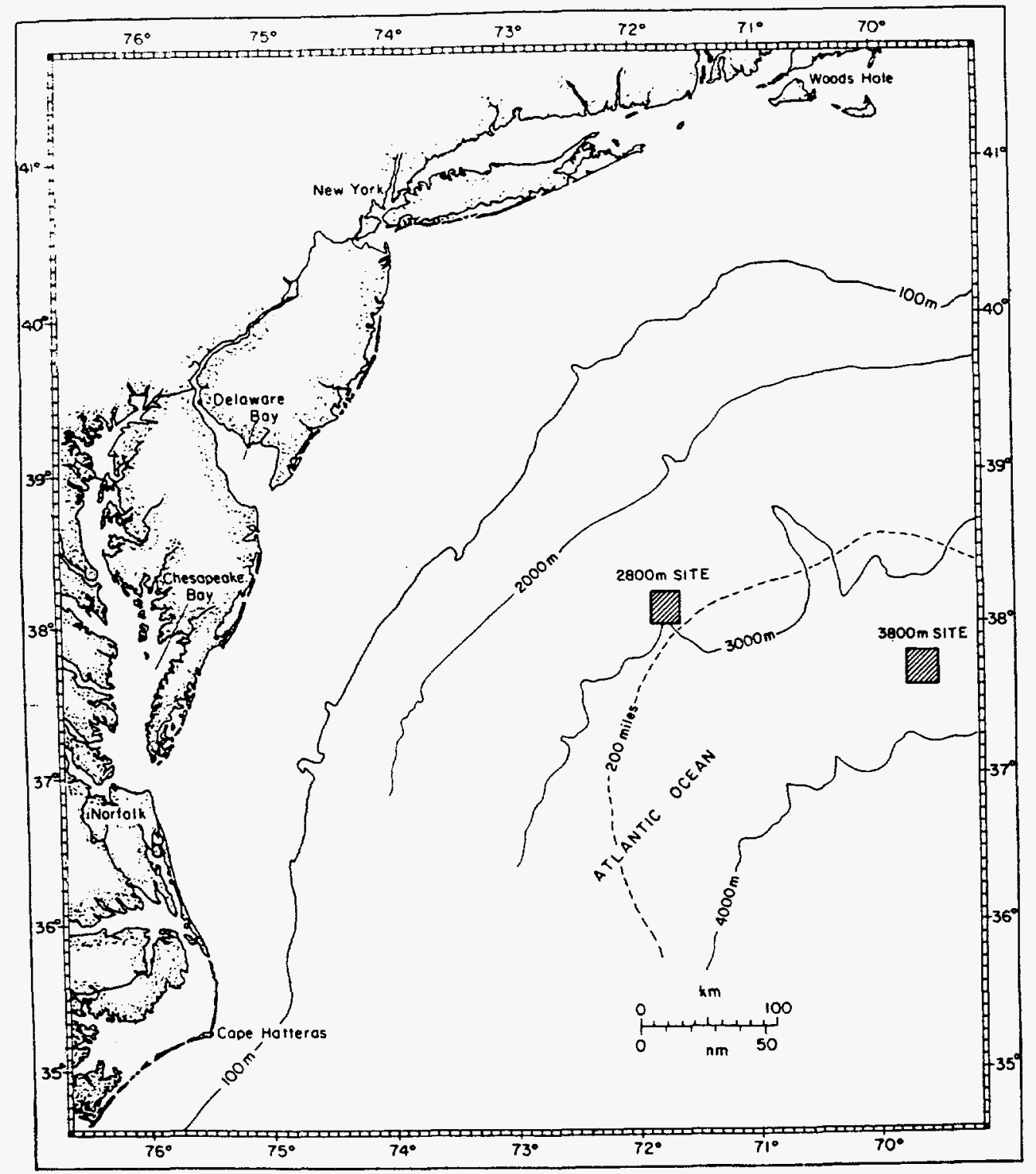

Figure 2.10 Major U.S. radioactive waste disposal sites in the Atlantic Ocean [4]. 


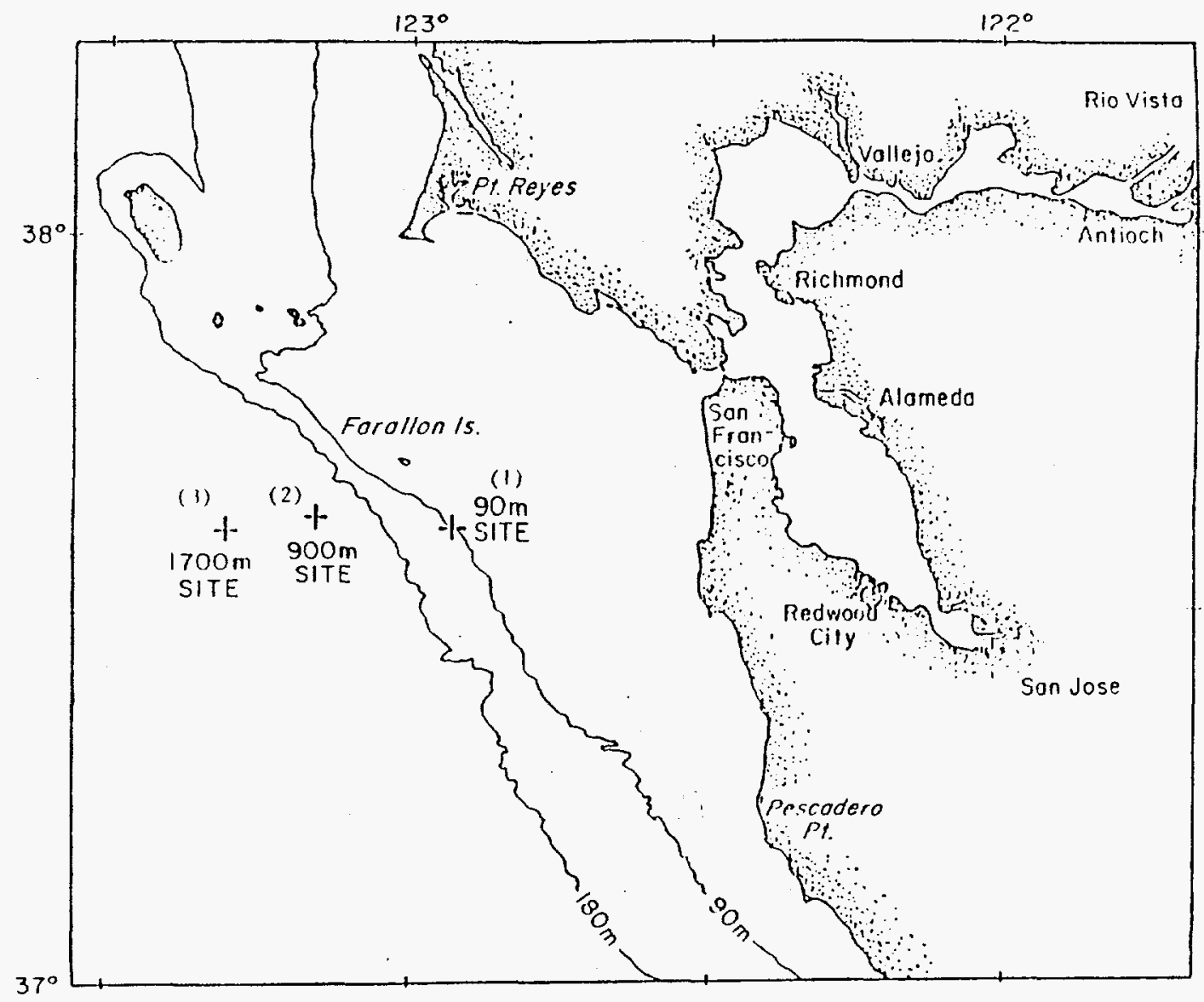

Figure 2.11 Farallon Islands radioactive waste disposal sites [3]. 
Table 2.9 Primary United States Ocean Disposal Sites for Low-Level Radioactive Waste [4]

\begin{tabular}{|c|c|c|c|c|c|c|c|}
\hline Site & $\begin{array}{l}\text { Coordinates } \\
\text { (Center of Site) }\end{array}$ & $\begin{array}{l}\text { Depth } \\
\text { (m) }\end{array}$ & $\begin{array}{l}\text { Distance } \\
\text { from Land } \\
(\mathrm{km})\end{array}$ & $\begin{array}{l}\text { Years Disposal } \\
\text { Site Used }\end{array}$ & $\begin{array}{l}\text { Estimated No. } \\
\text { of Disposed } \\
\text { 55-Gallon Drums }\end{array}$ & \multicolumn{2}{|c|}{$\begin{array}{l}\text { Estimated Activity in } \\
\text { Drums at Time of } \\
\text { Disposal }\end{array}$} \\
\hline Atlantic & $\begin{array}{l}38^{\circ} 30^{\prime} \mathrm{N} \\
72^{\circ} 06^{\prime} \mathrm{W}\end{array}$ & 2800 & 190 & $\begin{array}{l}1951-1956 \\
1959-1962\end{array}$ & 14,300 & $41,400(a)$ & 1530 \\
\hline Atlantic & $\begin{array}{l}37^{\circ} 38^{\prime} \mathrm{N} \\
70^{\circ} 35^{\prime} \mathrm{W}\end{array}$ & 3800 & 320 & $1957-1959$ & 14,500 & 2,100 & 77.7 \\
\hline $\begin{array}{l}\text { Pacific } \\
\text { Farallon Islands }\end{array}$ & $\begin{array}{c}37^{\circ} 38^{\prime} \mathrm{N} \\
123^{\circ} 08^{\prime} \mathrm{W}\end{array}$ & 900 & 60 & $1951-1953$ & 3,500 & 1,100 & 40.7 \\
\hline Farallon Islands & $\begin{array}{c}37^{\circ} 37^{\prime} \mathrm{N} \\
123^{\circ} 17^{\prime} \mathrm{W}\end{array}$ & 1700 & 77 & $\begin{array}{l}1946-1950 \\
1954-1965\end{array}$ & 44,000 & 13,400 & 496 \\
\hline
\end{tabular}

a. This does not include the pressure vessel of the N/S Seawolf reactor with an estimated induced activity of 33,000 Ci. (1220 T Bq) 
The upper part of the container (i.e. near the lid) was very severely corroded and part of the location adjacent to the rim had been perforated (Figs. 2.12 and 2.13). On the seaward side of the container loosely adhering black to red scale was present. The sediment side of the container was more severely attacked and most of the scale had already become detached. Parts of the container midsection were relatively free of corrosion. However, some local pitting was noticed beneath the container coating. Figures 2.14 and 2.15 show the differences in corrosion between the top and bottom of the container. As mentioned above the upper part of the container was most severely attacked as shown by the pitted surface appearance. The study showed that the general corrosion rate on the upper container surfaces was $1.3 \mathrm{mils} / \mathrm{y}(0.03 \mathrm{~mm} / \mathrm{y})$ on the seaward side and $1.9 \mathrm{mils} / \mathrm{y}(0.05 \mathrm{~mm} / \mathrm{y})$ on the sediment side. A lower limit for the pitting rate was estimated at $2.6 \mathrm{mils} / \mathrm{y}(0.07 \mathrm{~mm} / \mathrm{y})$.

Figure 2.16 shows severe corrosion in the regions adjacent to the chimes (the circumferencial protuberances on the containers). This type of attack near cold-worked material is present on both the sediment and seaward sides. Preferential attack was also noted near the welded region of the container. In addition "filiform" corrosion was noted beneath the coating on the container lid (Fig. 2.17). It has the appearance of a worm track along the metal/coating interface.

The effective lifetime of the container was calculated by the authors of this report using the rates for uniform corrosion given above. It was found that the container would lose its overall integrity as a barrier in 25-37 y. Note, however, that local attack in regions adjacent to the rim and chimes would cause perforation much earlier than this. Full details of this analysis are given in Reference 2.

\section{$\underline{3800 \text { Meter Atlantic Site [4] }}$}

In June, 1978, the submersible "Alvin" retrieved a waste package from the $3800 \mathrm{~m}$ Atlantic disposal sit (Fig. 2.18). A survey of this site showed that the current was southwesterly at $25-30 \mathrm{~cm} / \mathrm{sec}$. The current was sufficiently strong to prevent sediment build-up on the upper surface of the carbon steel container. The sediment side of the container showed more rapid corrosion (Fig. 2.19) and severe pitting was also noted (Fig. 2.20). In accordance with the $2800 \mathrm{~m}$ study, regions adjacent to the rim and chimes suffered severe attack and often perforation (Figs. 2.21 and 2.22). The total area of perforation was less than $1 \%$ of the container surface which was stated to be the lowest of the three containers taken from the various sites.

Estimates of the uniform corrosion rates were $0.2 \mathrm{mils} / \mathrm{y}(0.0045 \mathrm{~mm} / \mathrm{y}) \mathrm{max}$, , on the seaward side to $0.6 \mathrm{mils} / \mathrm{y}(0.015 \mathrm{~mm} / \mathrm{y})$ on the sediment side. It was estimated that based on uniform corrosion on the sediment side that it would take about 42 y to penetrate through $50 \%$ of the wall thickness of the container. However, local perforation by pitting would occur much sooner. Complete details of this study are given in Reference 4. 


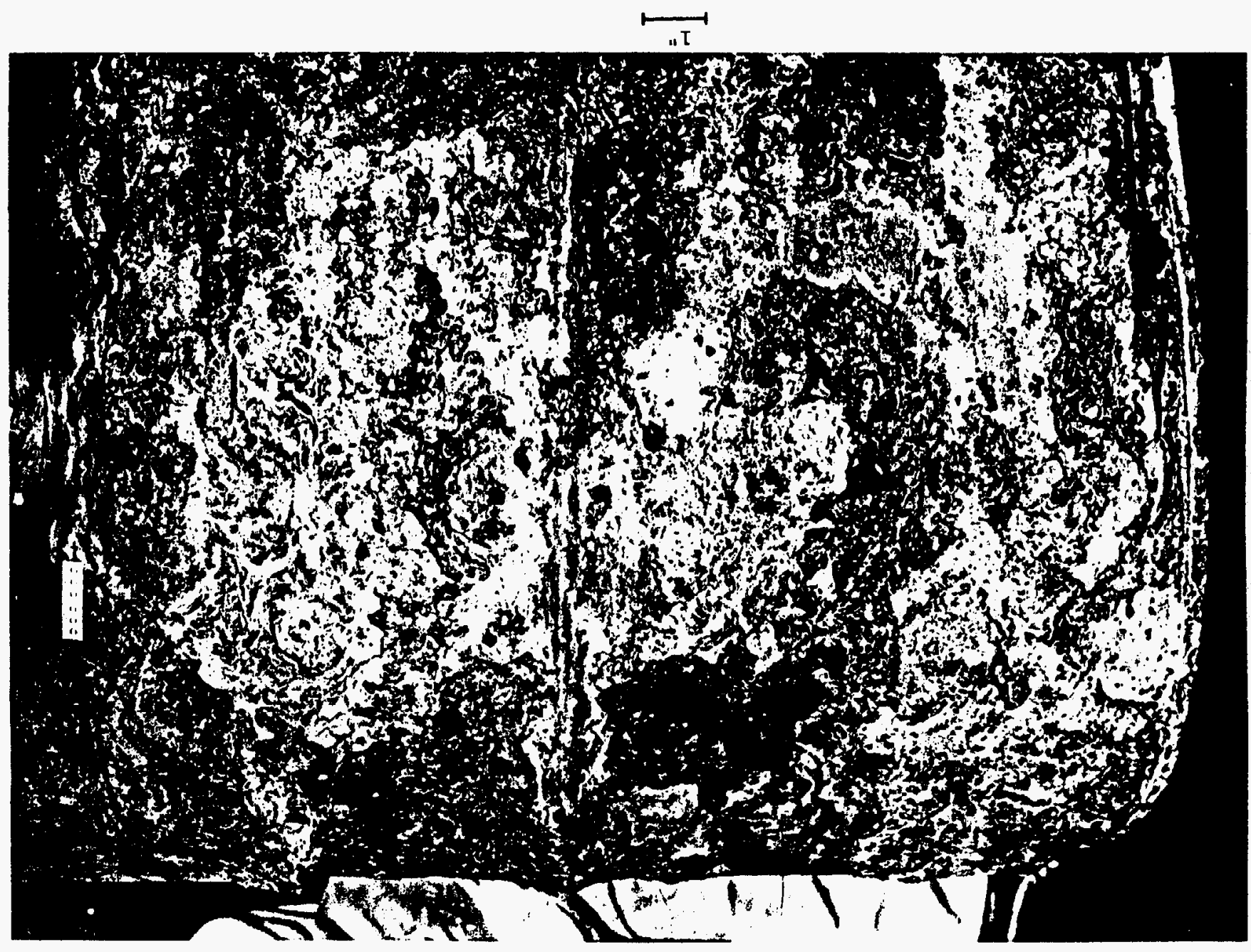




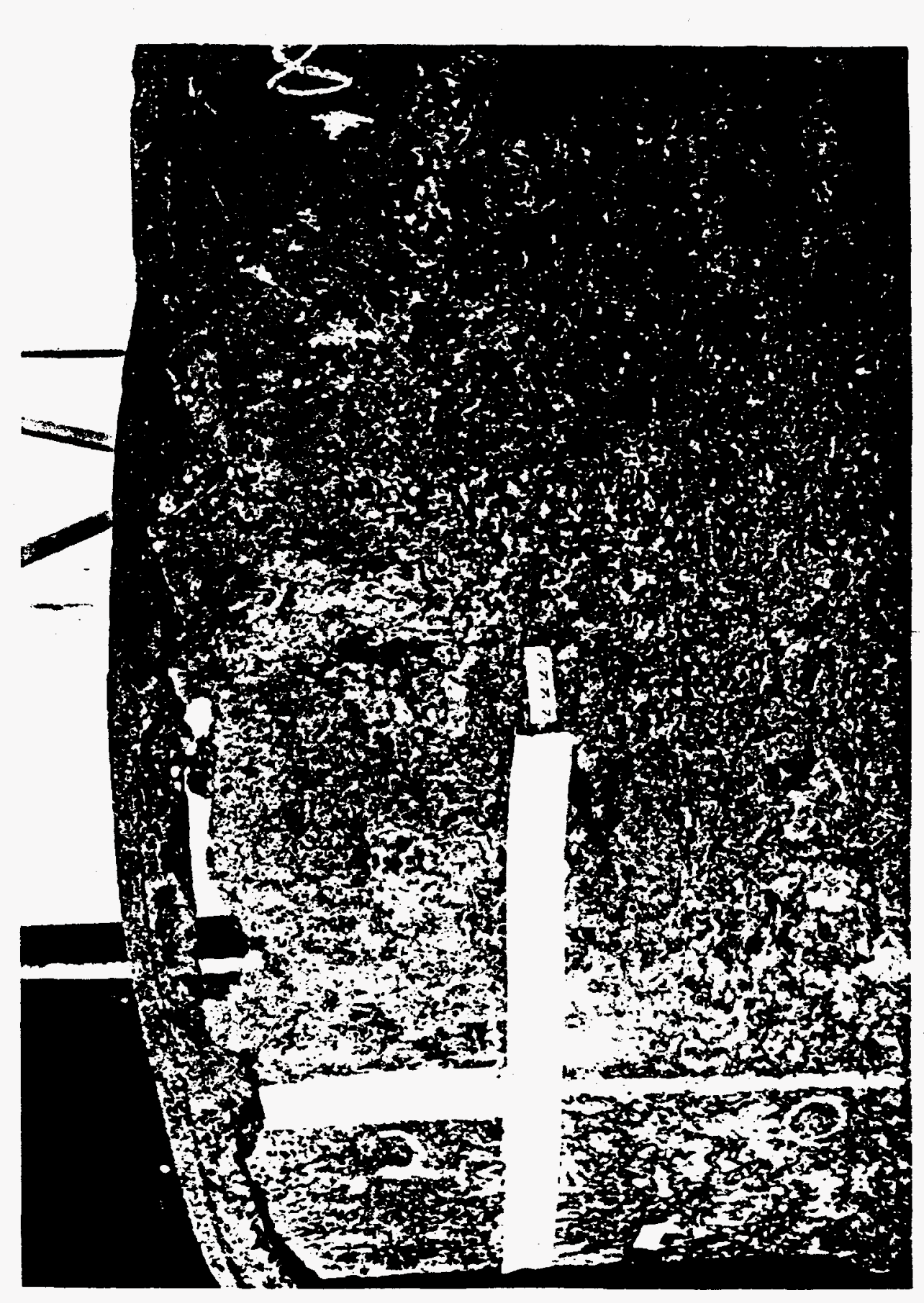

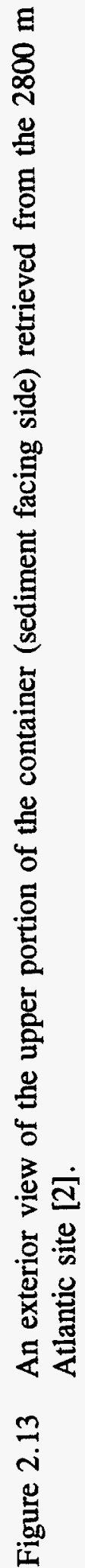




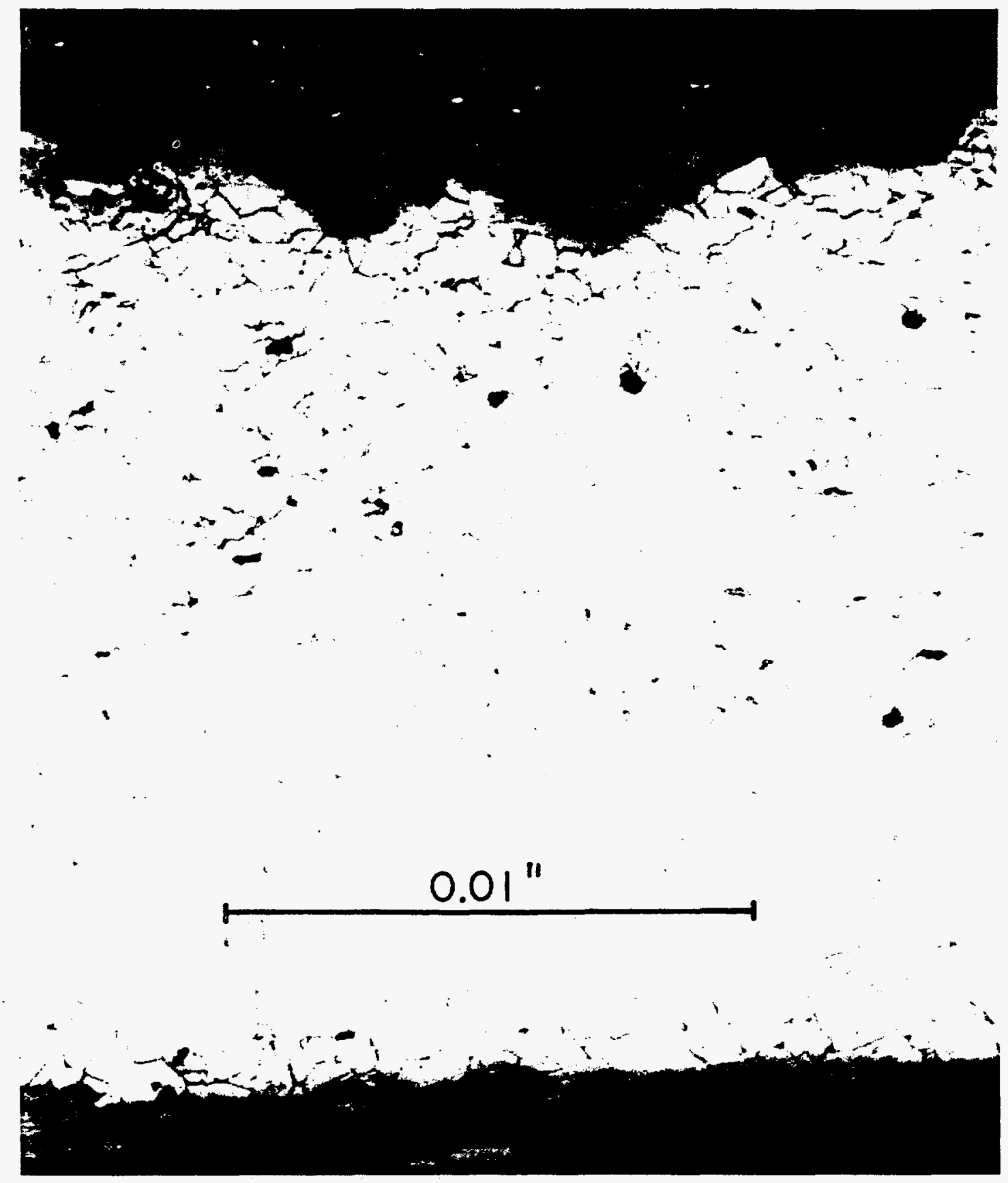

Figure 2.14 A typical metallographic cross section of the upper portion of the container retrieved from the $2800 \mathrm{~m}$ Atlantic site [2]. 


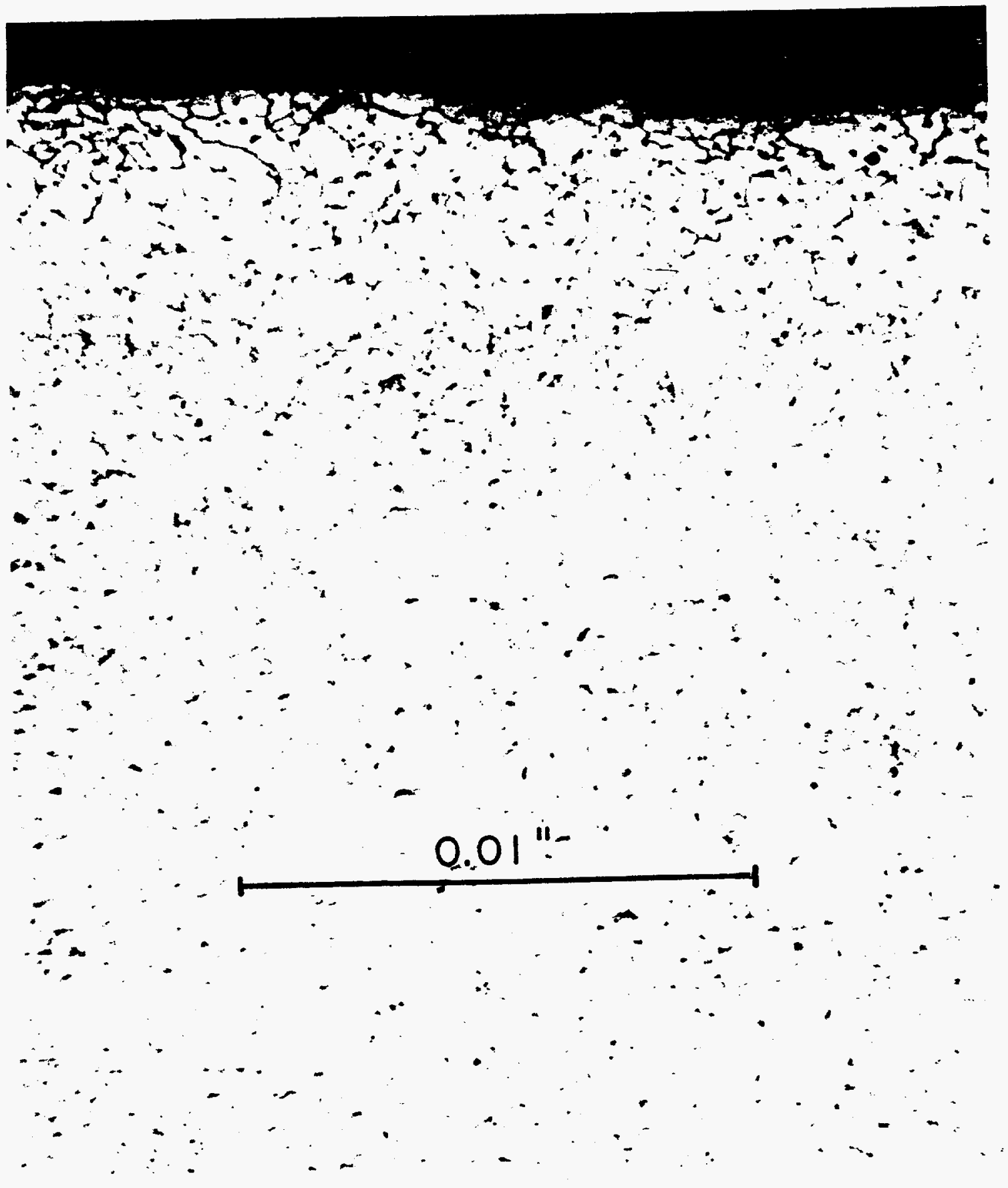

Figure 2.15 A typical metallographic cross section of the lower portion of the container retrieved from the $2800 \mathrm{~m}$ Atlantic site [2]. 


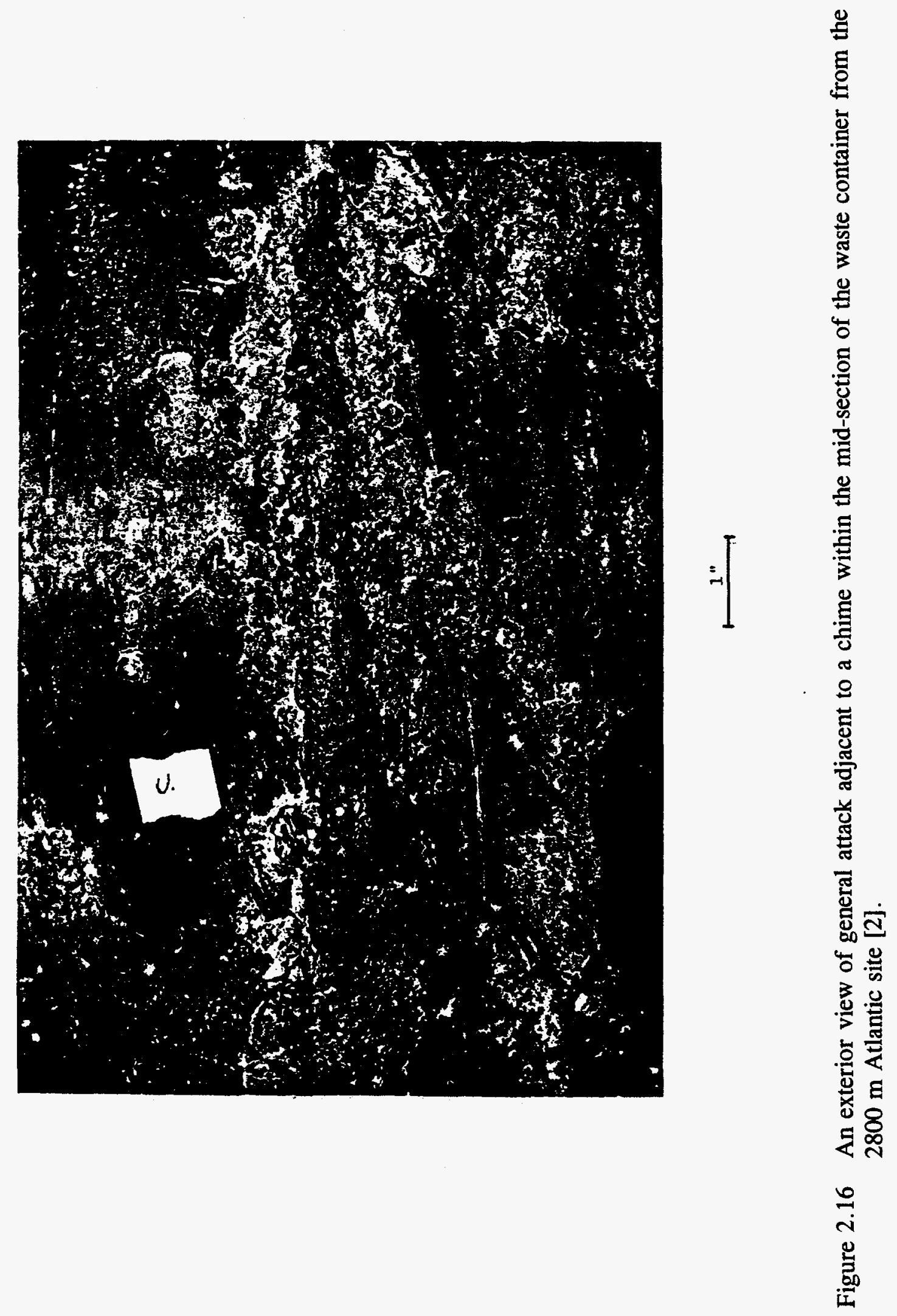




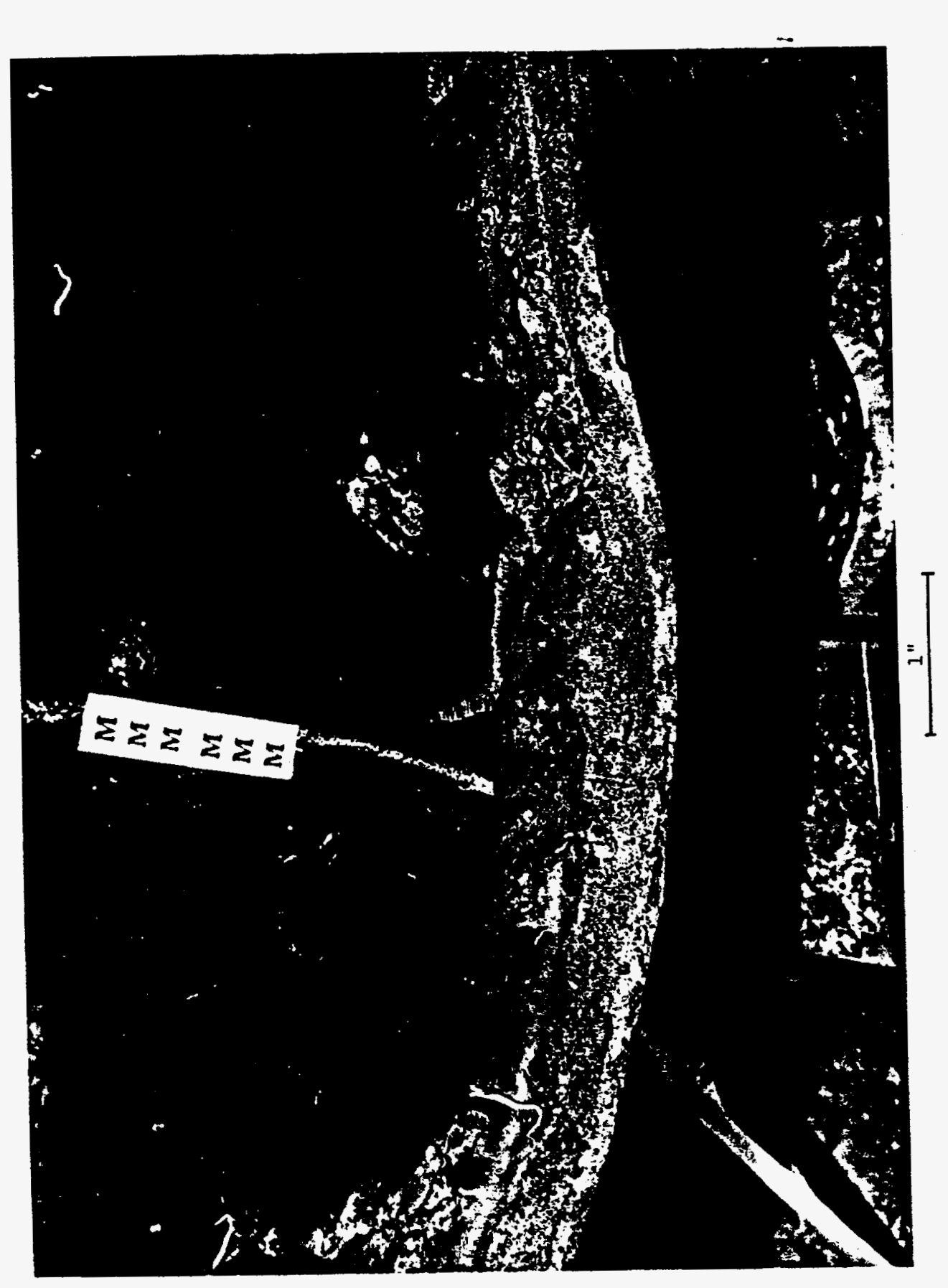

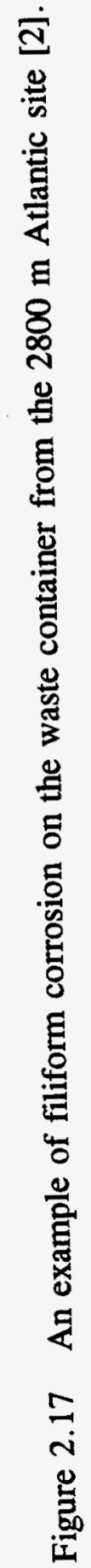




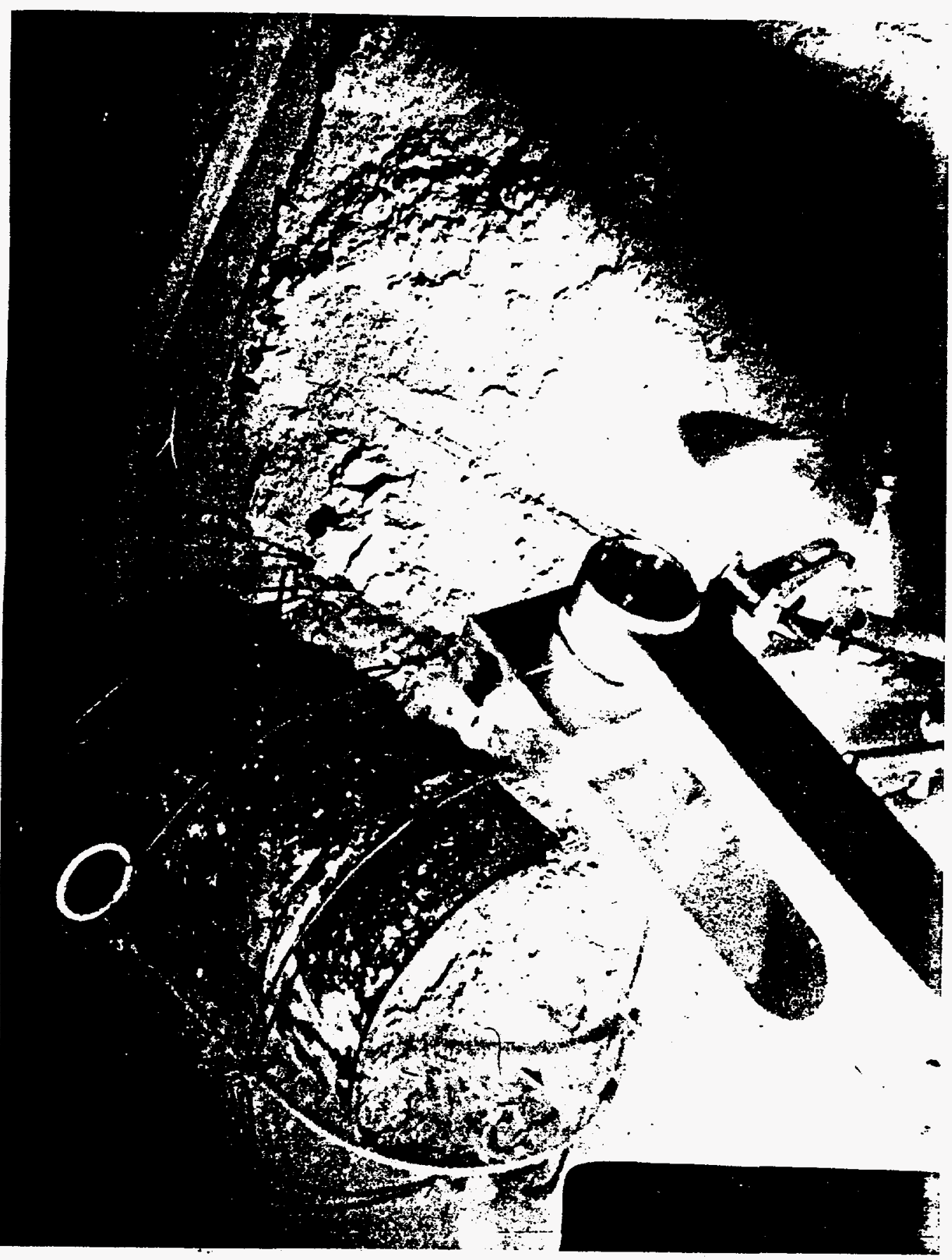

$\Xi$

ت

ํํำ

范

$\frac{0}{5}$

욤

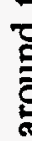

焉

త్

0

苞

를

蛋

i 


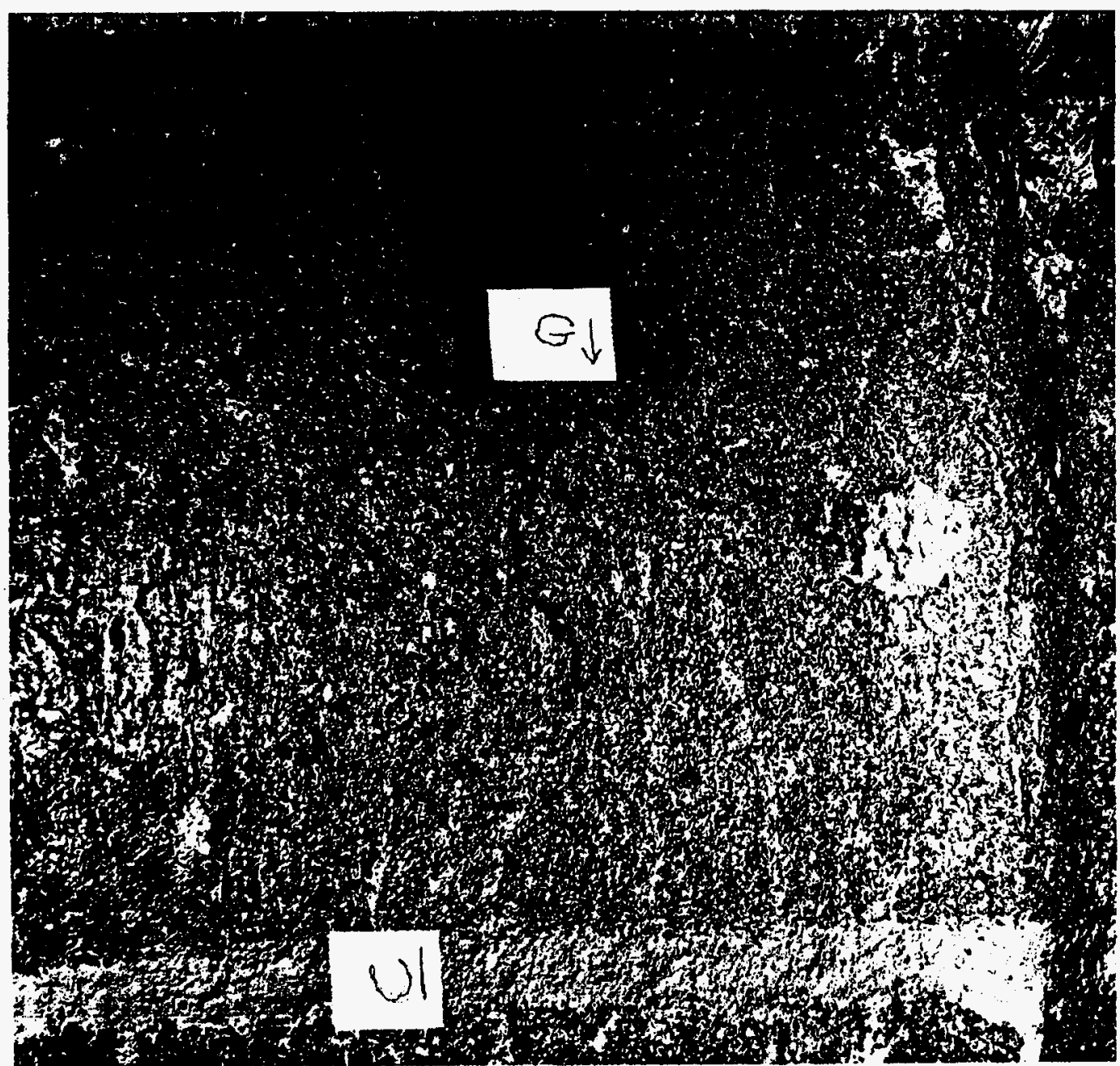

Figure 2.19 Close view of severe general attack on sediment side compared to the more protected sea side. Container retrieved from the $3800 \mathrm{~m}$ Atlantic site [4]. 


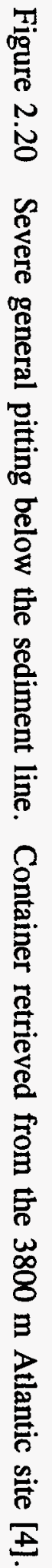

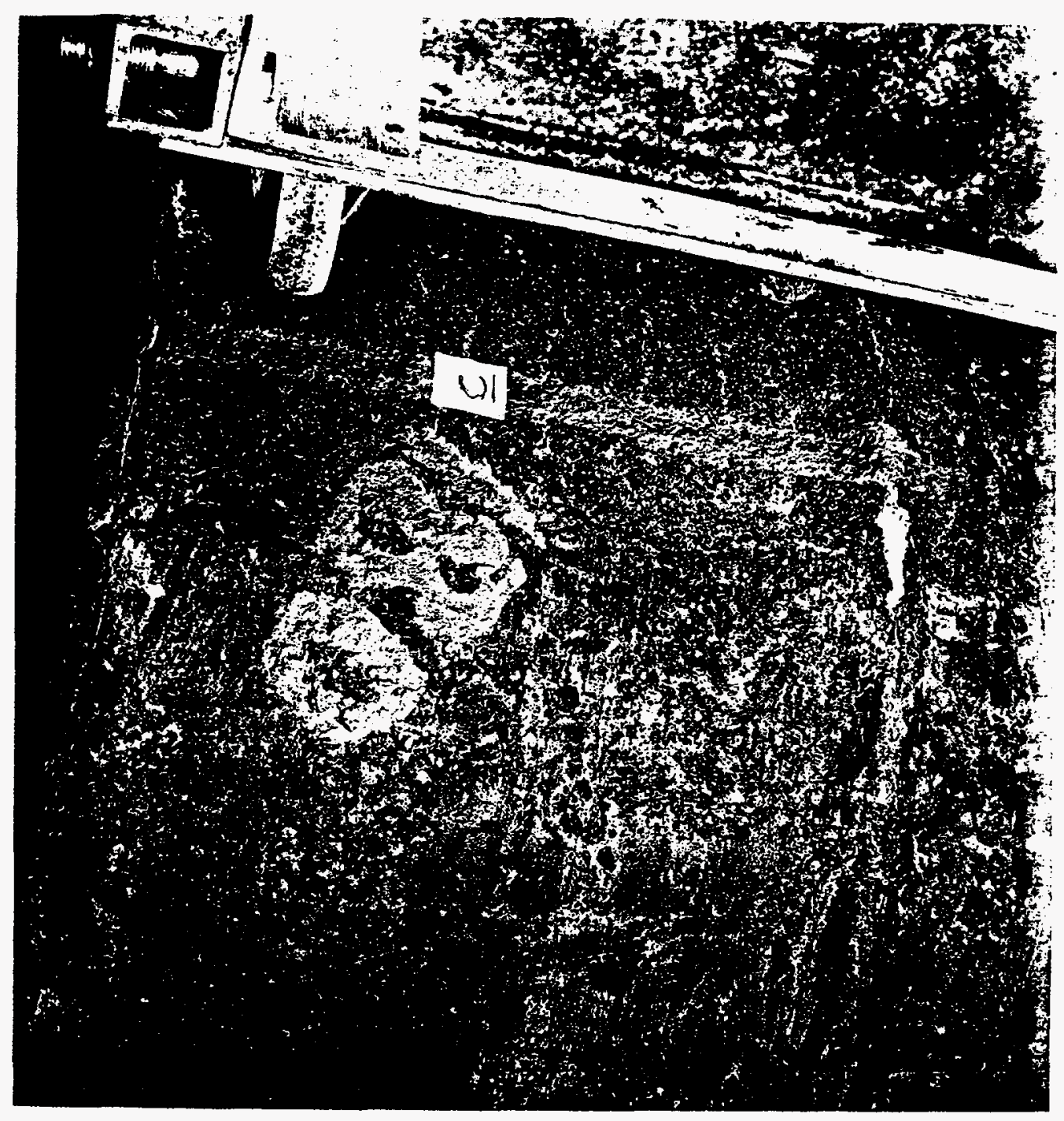




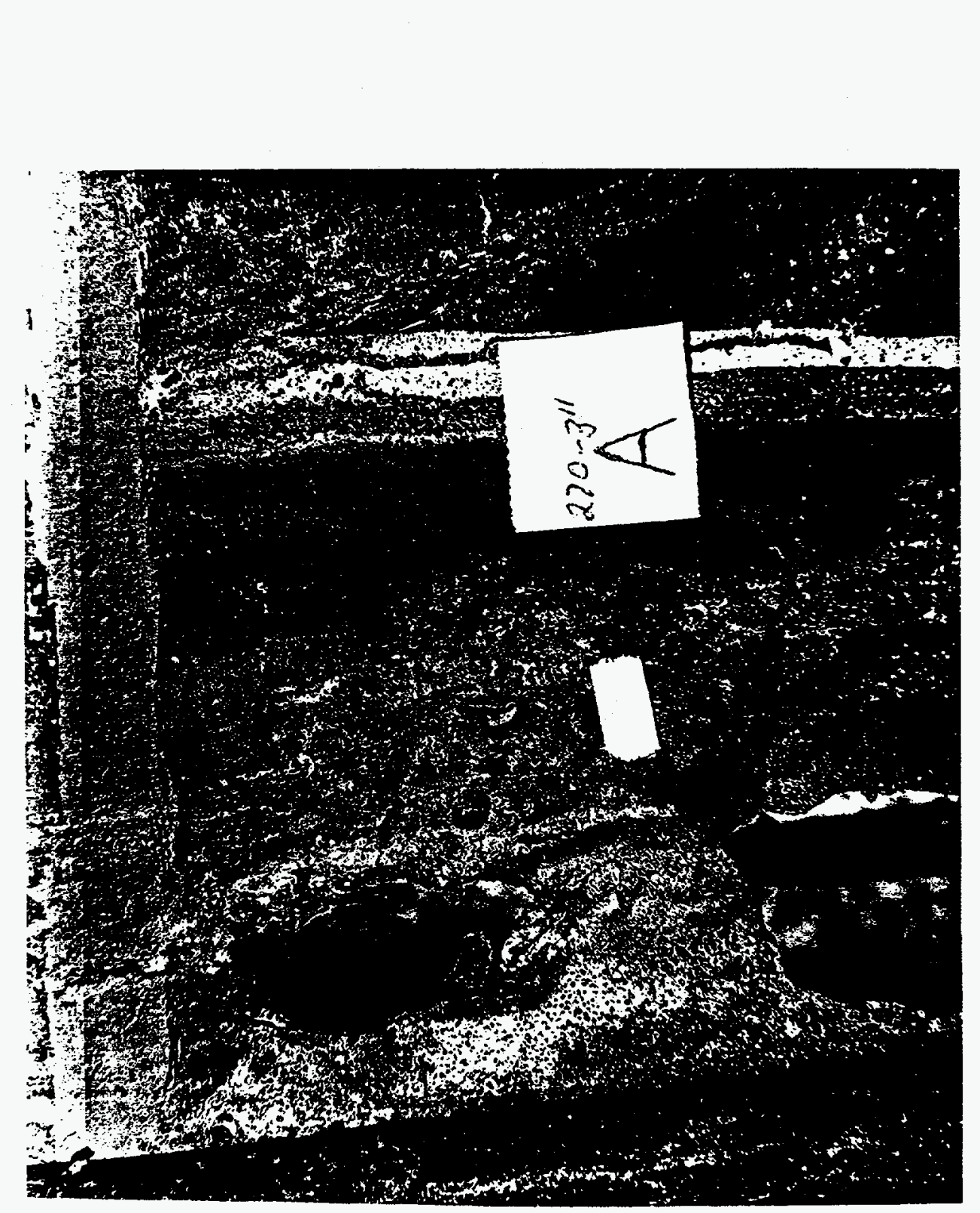

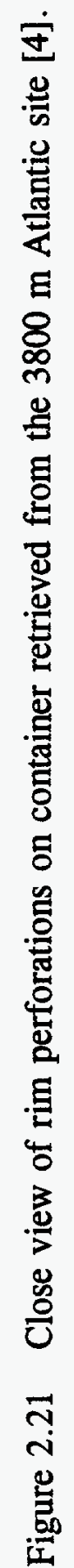



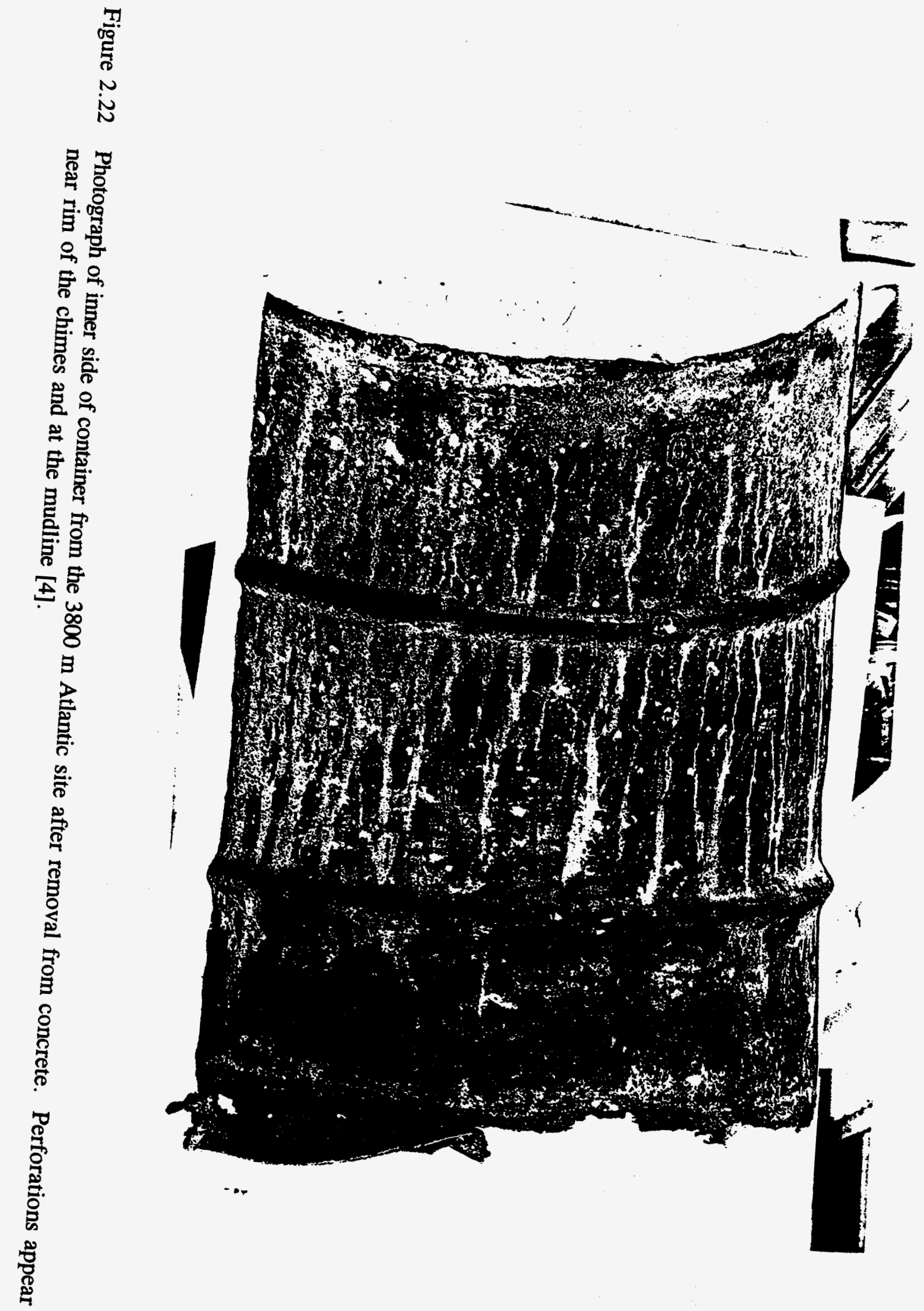


\section{Meter Pacific Site}

The Farallon Islands waste package was retrieved in 1977. Figure 2.23 shows a schematic of the types of package that were disposed of during this site's operational period. The package which was examined had been on the ocean floor for about 22 years and was covered with black to orange-red corrosion products. Upon retrieval there was a faint smell of hydrogen sulfide that indicated that it had been emplaced in an anoxic environment. Some pH measurements of the attached sediment gave values between 8 and 10 . For this container, however, the sediment side suffered minimal attack (about $0.1 \mathrm{mils} / \mathrm{y} ; 0.0025 \mathrm{~mm} / \mathrm{y}$ ) probably due to the site's location in a minimum oxygen zone, whereas the seaward side had a uniform corrosion rate of only $0.75 \mathrm{mils} / \mathrm{y}(0.02 \mathrm{~mm} / \mathrm{y})$. This would give a $50 \%$ penetration in about $34 \mathrm{y}$. Again, there was faster attack in local areas of cold work adjacent to the rims and chimes, especially on the seaward side. A complete description of this analysis is given in Reference 3.

Table 2.10 from Reference 4, summarizes the corrosion rates for the carbon steel containers taken from the three disposal sites. The most corrosive environment was at the $2800 \mathrm{~m}$ Atlantic site and the least at the $900 \mathrm{~m}$ Pacific location. As indicated above, uniform corrosion would corrode half way through the steel wall in several decades. However, local penetration at the rims and chimes would occur in far shorter times, although they could not be estimated accurately in the studies. Corrosion is usually more rapid on the sediment side of the steel container. Once penetration had occurred the waste form would be subjected to leaching and the release of radionuclides.

Coating of steel barriers for prolonging service life in seawater environments has often been used $[43,44,45]$. One of the more inexpensive organic coatings that may be used is paint. To be effective, the steel surfaces must be cleaned prior to painting and a suitable primer applied. Several top coats of paint increase integrity. Corrosion-resistant metals may also be deposited on the steel using electroplating or thermal spray techniques [45]. Zinc coating is applied using a hot-dipping process. Adequate testing should be carried out so that optimum coatings with respect to cost and performance may be determined.

\subsection{Corrosion of Austenitic Stainless Steels}

\subsubsection{Uniform Corrosion and Pitting}

The austenitic stainless steels (i.e., 300 series, gamma phase steels) are widely used in marine environments because of their tendency to form a thin passive oxide layer that gives a low rate of uniform corrosion. Table 2.11 gives the chemical compositions of these steels.

Schumacher [10] in his compilation of seawater corrosion data states that under fast seawater flow condition the stainless steels remain in a passive state because of contact with oxygenated waters. Maeda and Wadachi carried out some simulated deep ocean corrosion tests on Type 304 stainless steel as a comparison to their carbon steel corrosion studies described above [43]. After a 40 -month exposure at $44^{\circ} \mathrm{F}\left(6.7^{\circ} \mathrm{C}\right)$ only a thin layer of rust was observed. However, under certain conditions, stainless steels are susceptible to pitting and crevice attack. In shallow quite seawater in the Panama Canal Zone austenitic stainless steels had a uniform corrosion rate of up to $0.69 \mathrm{mils} / \mathrm{y}(0.18 \mathrm{~mm} / \mathrm{y})$ under fully immersed conditions [10]. 


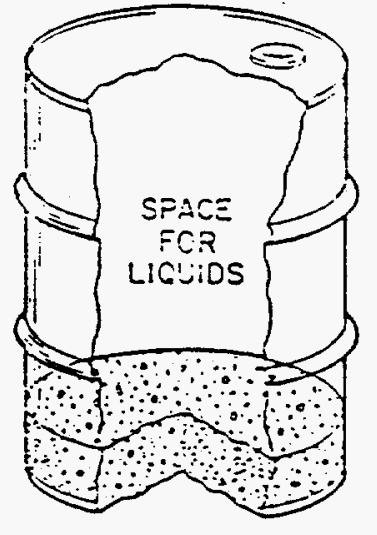

(a)

Weighted drum for

low level liquios

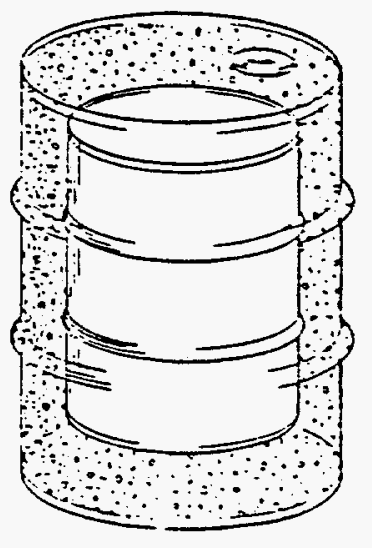

(c)

30 gallon drum of solidified liquios

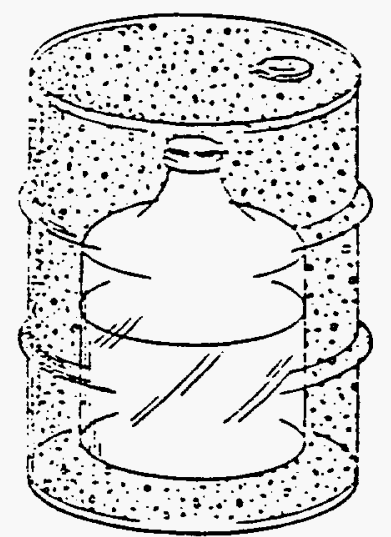

(b)

Carboy of low level liquids

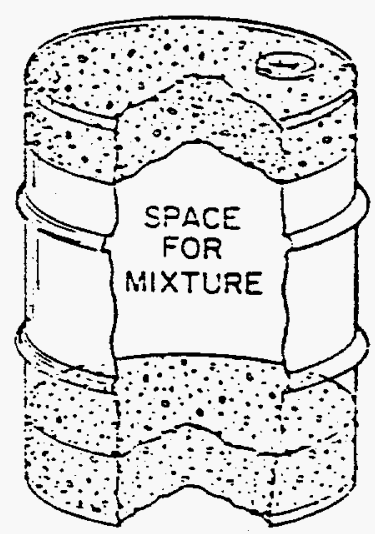

(d)

Mixture of solid waste materials ano concrete

Figure 2.23 Cut away isometric views showing modifications of 55-gallon drums for packaging radioactive wastes which were disposed of in the Farallon Islands $900 \mathrm{~m}$ disposal site. 
Table 2.10 Corrosion Rate Data for Waste Packages Retrieved from Deep Sea Disposal Sites [4]

\begin{tabular}{|l|c|c|}
\hline \multicolumn{1}{|c|}{ Waste Package } & Corrosion Rates inches $\mathrm{yr}^{-1}$ & Corrosion Rates $\mathrm{mm} \mathrm{yr}^{-1}$ \\
\hline \hline Atlantic 2800-meter Site & & \\
\hline Gen. Attack & $0.0013 \pm .0002$ & 0.033 \\
Sea Side & $0.0019 \pm .0002$ & 0.048 \\
Sediment Side & $>0.0026$ & $>0.066$ \\
Local Attack & & \\
\hline \hline Pacific 900-meter Site & $0.00075 \pm .00015$ & 0.019 \\
\hline Gen. Attack & 0 & 0 \\
Sea Side & $>0.0021$ & $>0.054$ \\
Sediment Side* & & $<0.0045$ \\
Local Attack & & 0.015 \\
\hline \hline Atlantic 3800-meter Site & $<0.0002$ & \\
\hline Gen. Attack & $0.0006 \pm 0.0001$ & \\
Sea Side & & \\
Sediment Side & & \\
\hline
\end{tabular}

* Microscopic examination suggests a shallow pitting and scale formation resulting in a calculated $0.0025 \mathrm{~mm} / \mathrm{yr}$. average. 
Table 2.11 AISI and ACI Standard Composition Ranges for Wrought and Cast Chromium-Nickel Stainless Steels American Iron and Steel Institute Classification of Chromium-Nickel Stainless Steels [46]

\begin{tabular}{|c|c|c|c|c|c|c|c|c|c|}
\hline \multirow[b]{2}{*}{$\begin{array}{l}\text { AISI } \\
\text { Type }\end{array}$} & \multicolumn{9}{|c|}{ Composition, $\%$} \\
\hline & $\begin{array}{c}\mathrm{C} \\
\max \end{array}$ & $\begin{array}{l}\text { Mn } \\
\max \end{array}$ & $\begin{array}{c}\mathrm{P} \\
\max \end{array}$ & $\begin{array}{c}S \\
\max \end{array}$ & $\begin{array}{c}\mathrm{Si} \\
\max \end{array}$ & $\mathrm{Cr}$ & Ni & Mo & Other \\
\hline 201 & 0.15 & $5.50-7.50$ & .060 & .030 & 1.00 & $16.00-18.00$ & $3.50-5.50$ & -- & N.025 max \\
\hline 202 & 0.15 & $7.50-10.00$ & .060 & .030 & 1.00 & $17.00-19.00$ & $4.00-6.00$ & -- & N .025 max \\
\hline 301 & 0.15 & 2.00 & .045 & .030 & 1.00 & $16.00-18.00$ & $6.00-8.00$ & -- & -- \\
\hline 302 & 0.15 & 2.00 & .045 & .030 & 1.00 & $17.00-19.00$ & $8.00-10.00$ & -- & -- \\
\hline $302 B$ & 0.15 & 2.00 & .045 & .030 & $2.00-3.00$ & $17.00-19.00$ & $8.00-10.00$ & -- & -- \\
\hline 303 & 0.15 & 2.00 & 0.20 & $0.15 \mathrm{~min}$ & 1.00 & $17.00-19.00$ & $8.00-10.00$ & $0.60 \max$ & -- \\
\hline 303Se & 0.15 & 2.00 & 0.20 & .06 & 1.00 & $17.00-19.00$ & $8.00-10.00$ & -- & $\mathrm{Se} 0.15 \mathrm{~min}$ \\
\hline 304 & .08 & 2.00 & .045 & .030 & 1.00 & $18.00-20.00$ & $8.00-12.00$ & -- & -- \\
\hline $304 \mathrm{~L}$ & .03 & 2.00 & .045 & .030 & 1.00 & $18.00-20.00$ & $8.00-12.00$ & - & -- \\
\hline 305 & 0.12 & 2.00 & .045 & .030 & 1.00 & $17.00-19.00$ & $10.00-13.00$ & -- & -- \\
\hline 308 & .08 & 2.00 & .045 & .030 & 1.00 & $19.00-21.00$ & $10.00-12.00$ & -- & -- \\
\hline 309 & 0.20 & 2.00 & .045 & .030 & 1.00 & $22.00-24.00$ & $12.00-15.00$ & -- & -- \\
\hline $309 \mathrm{~S}$ & .08 & 2.00 & .045 & .030 & 1.00 & $22.00-24.00$ & $12.00-15.00$ & -- & -- \\
\hline 310 & 0.25 & 2.00 & .045 & .030 & 1.50 & $24.00-26.00$ & $19.00-22.00$ & -- & -- \\
\hline $310 S$ & .08 & 2.00 & .045 & .030 & 1.50 & $24.00-26.00$ & $19.00-22.00$ & -- & -- \\
\hline 314 & 0.25 & 2.00 & .045 & .030 & $1.50-3.00$ & $23.00-26.00$ & $19.00-22.00$ & -- & -- \\
\hline 316 & .08 & 2.00 & .045 & .030 & 1.00 & $16.00-18.00$ & $10.00-14.00$ & $2.00-3.00$ & -- \\
\hline $316 \mathrm{~L}$ & .03 & 2.00 & .045 & .030 & 1.00 & $16.00-18.00$ & $10.00-14.00$ & $2.00-3.00$ & -- \\
\hline 317 & .08 & 2.00 & .045 & .030 & 1.00 & $18.00-20.00$ & $11.00-15.00$ & $3.00-4.00$ & -- \\
\hline D319 & .07 & 2.00 & .045 & .030 & 1.00 & $17.50-19.50$ & $11.00-15.00$ & $2.25-3.00$ & -- \\
\hline 321 & .08 & 2.00 & .045 & .030 & 1.00 & $17.00-19.00$ & $9.00-12.00$ & -- & Ti $5 \times \mathrm{C} \min$ \\
\hline 347 & .08 & 2.00 & .045 & .030 & $\cdot 1.00$ & $17.00-19.00$ & $9.00-13.00$ & -- & $\mathrm{Cb}-\mathrm{Ta} 10 \times \mathrm{C} \min$ \\
\hline 348 & .08 & 2.00 & .045 & .030 & 1.00 & $17.00-19.00$ & $9.00-13.00$ & -- & $\begin{array}{c}\text { Cb-Ta } 10 \text { x C min; } \\
\text { Ta } \\
0.10 \text { max; Co } 0.20 \\
\max \end{array}$ \\
\hline
\end{tabular}


Some pits that developed were up to 245 mils deep in Type 316 stainless steel after 8 y (Table 2.12). Other results for pitting in surface seawater are in general agreement with these values (Tables 2.13 and 2.14) [46]. Figure 2.23 shows a plot of some very long-term uniform corrosion data [8]. There is an initial high rate of attack but it decreases to a constant value after 2-3 y.

Data are also available for the uniform corrosion of stainless steels under deep ocean (3000 and $3700 \mathrm{~m}$ ) north Atlantic conditions [35] (Table 2.15). As noted above for the carbon and low alloy steel corrosion results, the oxygen level at both sites is about $7 \mathrm{mg} / \mathrm{L}$, the water flow rate between $5-10 \mathrm{~cm}$. $/ \mathrm{sec}$, and the temperature $3{ }^{\circ} \mathrm{C}$. Note that the rates for uniform corrosion are averaged values obtained from descaled weight loss measurements of the samples. A significant fraction of this loss was from pitting. The $3700 \mathrm{~m}$ Deep Ocean Station (DOS) results indicate that in flowing seawater the rate of attack is significantly less than for stagnant or semi-stagnant conditions for tests lasting for one year. This could be explained on the basis of abundant oxygen that would maintain the passivation of the steel. For tests lasting up to three years, however, the corrosion rate has decreased to only about $0.1 \mathrm{mil} / \mathrm{y}(0.0025 \mathrm{~mm} / \mathrm{y})$. For the three year tests at $3700 \mathrm{~m}$, the stainless steel samples in contact with sediment have a faster corrosion rate although the rate is still small $(0.9 \mathrm{mils} / \mathrm{y} ; 0.02 \mathrm{~mm} / \mathrm{y})$. Corrosion results for samples in the test stand at the $3000 \mathrm{~m}$ site are not comprehensive but in flowing seawater the corrosion rates are higher than for the $3700 \mathrm{~m}$ site. For corrosion in the sediment the rate at $3000 \mathrm{~m}$ is higher than that for $3700 \mathrm{~m}$. The average corrosion rate for stainless steel for all environments was calculated to be $0.007 \mathrm{mils} / \mathrm{y}(0.00018 \mathrm{~mm} / \mathrm{y})$. The maximum value observed for an individual specimen was $0.15 \mathrm{mils} / \mathrm{y}(0.38 \mathrm{~mm} / \mathrm{y})$. Therefore, on average, a 50 mil container would fail from "uniform" corrosion in about $7000 \mathrm{y}$. Assuming the maximum attack rate, this would decrease to $333 \mathrm{y}$.

\subsubsection{Crevice Corrosion}

This type of attack is possible in stainless steels. It is basically similar to pitting attack in that it occurs in regions of stagnant water flow conditions which allow chloride accumulation and decreases in $\mathrm{pH}$. The major possibility for this type of attack would be in the region of the container lid where it is fastened to the body of the container. The rate of corrosion would be specific to the geometry of the crevice and the seawater conditions. Table 2.16 shows crevice corrosion data under deep ocean conditions [8]. At $700 \mathrm{~m}$ (2340 ft.), where the oxygen level was $0.6 \mathrm{ppm}$, crevice attack after $197 \mathrm{~d}$ varied in depth between zero and 25 mils $(0.64 \mathrm{~mm})$ depending on the type of stainless steel. Pitting was also observed in these crevice corrosion tests. At a depth of $1600 \mathrm{~m}(5300 \mathrm{ft}$., where the oxygen level was $1.7 \mathrm{ppm}$ the deepest pits after $1064 \mathrm{~d}$ were about $27 \mathrm{mils}(0.69 \mathrm{~mm})$.

\subsubsection{Stress-Corrosion Cracking}

A comprehensive survey was carried out to determine the conditions for which austenitic stainless steels undergo stress-corrosion cracking in chloride environments [47]. For chloride levels up to $1 \%$, no failures were present below a temperature of $55^{\circ} \mathrm{C}\left(131^{\circ} \mathrm{F}\right)$. Other studies have also indicated that no stress-corrosion cracking has ever been observed under submerged ocean conditions $[35,48]$. 
Table 2.12 Comprehensive Evaluation of Corrosion Damage of Stainless Steels, Exposed to Marine Environment in the Panama Canal Zone [10]

\begin{tabular}{|c|c|c|c|c|c|c|c|c|c|c|c|c|c|}
\hline \multirow[b]{2}{*}{ Metal } & \multirow[b]{2}{*}{$\begin{array}{l}\text { Stainless } \\
\text { Steel }\end{array}$} & \multirow[b]{2}{*}{ Type of Exposure } & \multicolumn{3}{|c|}{ Corrosion Rate mpy } & \multicolumn{3}{|c|}{$\begin{array}{l}\text { Average of } 20 \text { Deepest } \\
\text { Pits (a) mil }\end{array}$} & \multicolumn{3}{|c|}{ Deepest Pit (a) mil } & \multirow{2}{*}{$\begin{array}{c}\begin{array}{c}\text { Loss in } \\
\text { Tensile } \\
\text { Strength } \\
\text { percent (b) }\end{array} \\
4 \mathrm{Yr}\end{array}$} & \multirow{2}{*}{$\begin{array}{c}\begin{array}{c}\text { Type of } \\
\text { Corrosion } \\
\text { Attack }\end{array} \\
4 \mathrm{Yr}\end{array}$} \\
\hline & & & $1 \mathrm{Yr}$ & $4 \mathrm{Yr}$ & $8 \mathrm{Yr}$ & $1 \mathrm{Yr}$ & $4 \mathrm{Yr}$ & $8 \mathrm{Yr}$ & $1 \mathrm{Yr}$ & $4 \mathrm{Yr}$ & $8 \mathrm{Yr}$ & & \\
\hline A & $\begin{array}{c}\text { Type } 301 \\
(17 \mathrm{Cr}, 7 \\
\mathrm{Ni})\end{array}$ & Seashore & 0.00 & 0.001 & 0.001 & $0(0)$ & $0(0)$ & $0(0)$ & $0(0)$ & $0(0)$ & $0(0)$ & 0 & $\mathbf{K}$ \\
\hline B & $\begin{array}{l}\text { Type } 302 \\
(18 \mathrm{Cr}, 8 \\
\mathrm{Ni})\end{array}$ & $\begin{array}{l}\text { Seawater immersion } \\
\text { Seawater mean tide }\end{array}$ & $\begin{array}{l}1.46 \\
0.18\end{array}$ & $\begin{array}{l}0.88 \\
0.12\end{array}$ & $\begin{array}{l}0.69 \\
0.11\end{array}$ & $\begin{array}{l}70(12) \\
7(13)\end{array}$ & $\begin{array}{c}107 \\
26\end{array}$ & $\begin{array}{c}140 \\
57\end{array}$ & $\begin{array}{c}261(p) \\
16\end{array}$ & $\begin{array}{c}286(p) \\
82\end{array}$ & $\begin{array}{l}236 \\
110\end{array}$ & $\begin{array}{c}\text { (d) } \\
0\end{array}$ & $\begin{array}{l}\mathrm{KQ} \\
\mathrm{JK}\end{array}$ \\
\hline C & $\begin{array}{c}\text { Type } 316 \\
(18-13 \text { and } \\
\text { Mo) }\end{array}$ & $\begin{array}{c}\text { Seawater immersion } \\
\text { Seawater mean tide } \\
\text { Seashore }\end{array}$ & $\begin{array}{l}0.59 \\
0.06 \\
0.00\end{array}$ & $\begin{array}{l}0.07 \\
0.03 \\
0.00\end{array}$ & $\begin{array}{l}0.25 \\
0.02 \\
0.00\end{array}$ & $\begin{array}{l}44(7) \\
5(9) \\
0(0)\end{array}$ & $\begin{array}{c}48 \\
7(12) \\
0(0)\end{array}$ & $\begin{array}{c}154 \\
16 \\
0(0)\end{array}$ & $\begin{array}{c}245(p) \\
23 \\
0(0)\end{array}$ & $\begin{array}{c}93 \\
22 \\
0(0)\end{array}$ & $\begin{array}{c}245(\mathrm{p}) \\
30 \\
0(0)\end{array}$ & $\begin{array}{l}0 \\
1 \\
1\end{array}$ & $\begin{array}{c}\mathrm{KQ} \\
\mathrm{JK} \\
\mathrm{K}\end{array}$ \\
\hline D & $\begin{array}{c}\text { Type } 321 \\
(17-10 \text { and } \\
\text { Ti) }\end{array}$ & $\begin{array}{c}\text { Seawater immersion } \\
\text { Seawater mean tide } \\
\text { Seashore }\end{array}$ & $\begin{array}{l}1.16 \\
0.13 \\
0.005\end{array}$ & $\begin{array}{c}0.81 \\
0.08 \\
0.001\end{array}$ & $\begin{array}{c}0.62 \\
0.08 \\
0.001\end{array}$ & $\begin{array}{l}64(8) \\
8(11) \\
0(0)\end{array}$ & $\begin{array}{c}175 \\
37 \\
0(0)\end{array}$ & $\begin{array}{c}193 \\
56 \\
0(0)\end{array}$ & $\begin{array}{l}270(p) \\
26 \\
0(0)\end{array}$ & $\begin{array}{c}273(p) \\
60 \\
0(0)\end{array}$ & $\begin{array}{l}272(p) \\
93 \\
0(0)\end{array}$ & $\begin{array}{l}\text { (d) } \\
\text { (d) } \\
1\end{array}$ & $\begin{array}{c}\text { KQ } \\
\text { JKQ } \\
\text { K }\end{array}$ \\
\hline
\end{tabular}

(a) Pit depths referred to the original surface of the metal either by measurement from an uncorroded surface or by calculation using the original and final average measured thickness of the sample. Average of 20 deepest pits represents average of the 5 deepest pits measured on each side of duplicate specimens. (Area 2.25 on immersed specimens, and 0.89 sq ft on atmospheric specimens) values in parentheses indicate total number averaged when less than 20 measurable pits. Perforation of plate by deepest pits is indicated by (p).

(b) Changes in tensile strength calculated on basis of $1 / 4$ inch thick metal (average of 4 tests for immersed specimens, average of 3 tests on atmospheric specimens)

(c) $\mathrm{H}$ - concentration cell, $\mathrm{J}$ - marine fouling contact, $\mathrm{K}$ - no visible attack, Q - pitting attack (random), $\mathrm{R}$ - localized attack (random).

(d) Intensity and distribution of pitting prevented satisfactory tensile testing. 
Table 2.13 Corrosion Behavior of Austenitic Stainless Steels in Seawater Moving at Low Velocity [46]

\begin{tabular}{|c|c|c|c|c|c|c|c|}
\hline \multirow{3}{*}{$\begin{array}{l}\text { AISI } \\
\text { Type }\end{array}$} & \multirow{3}{*}{$\begin{array}{c}\text { Duration } \\
\text { of Test, } \\
\text { days }\end{array}$} & \multirow{3}{*}{$\begin{array}{l}\text { Wt } \\
\text { Loss, } \\
\text { g }\end{array}$} & \multicolumn{4}{|c|}{ Depth of Pitting, mils } & \multirow{3}{*}{ Remarks } \\
\hline & & & \multicolumn{2}{|c|}{$\begin{array}{l}\text { Under } \\
\text { Deposits }\end{array}$} & \multicolumn{2}{|c|}{ In Crevices } & \\
\hline & & & $\max$ & avg & $\max$ & avg & \\
\hline 302 & 643 & 24 & $>50^{2}$ & 31 & $\mathrm{nr}^{\mathrm{b}}$ & $\mathrm{nr}$ & 12 in. $x 12$ in. $x .050$ in. \\
\hline 304 & 320 & 12 & 35 & 22 & 36 & 24 & Pickled \\
\hline 304 & 365 & 6 & $>62$ & $>62$ & $\mathrm{nr}$ & $\mathrm{nr}$ & 4 in. $x 12$ in. $x .062$ in. \\
\hline 347 & 755 & 30 & 79 & 54 & 47 & 38 & $\begin{array}{l}12 \text { in. } \times 12 \text { in., hot rolled, } \\
\text { pickled }\end{array}$ \\
\hline 321 & 944 & $\mathbf{n r}^{\mathrm{b}}$ & 53 & 15 & 56 & 24 & 12 in. $\times 12$ in. \\
\hline 316 & 365 & 2.7 & 55 & 13 & 56 & 56 & 4 in. $\times 12$ in. $\times .062$ in. \\
\hline 316 & 730 & 3.9 & 26 & 10 & 56 & 56 & 4 in. $x 12$ in. $x .062$ in. \\
\hline 316 & 1255 & 3 & 50 & 22 & 170 & 46 & Hot rolled, pickled \\
\hline $\begin{array}{l}316 \\
(2.4 \\
\text { Mo) }\end{array}$ & 2773 & 8 & 34 & 16 & $\mathrm{nr}$ & $\mathrm{nr}$ & 12 in. $x 12$ in. $x .050$ in. \\
\hline $\begin{array}{l}316 \\
(3.18 \\
\text { Mo) }\end{array}$ & 3164 & 3 & 25 & 11 & $\mathrm{nr}$ & $\mathrm{nr}$ & 12 in. $x 12$ in. $x .050$ in. \\
\hline 317 & 1075 & 5 & 23 & 12 & 45 & 27 & Hot rolled, \#4 finish \\
\hline 305 & 198 & 19 & 4 & 2 & $\mathrm{nr}$ & $\mathrm{nr}$ & $\mathrm{nr}^{\mathrm{b}}$ \\
\hline 308 & 755 & 28 & 205 & 83 & 141 & 66 & $\begin{array}{l}12 \text { in. } \times 12 \text { in., hot } \\
\text { rolled, } \# 4 \text { finish }\end{array}$ \\
\hline 309 & 320 & 11 & 26 & 12 & $>55^{\mathrm{a}}$ & $>55^{a}$ & Pickled \\
\hline 310 & 320 & 4 & 6 & 3 & $>24^{a}$ & $>24^{a}$ & Pickled \\
\hline 325 & 106 & 60 & 56 & 56 & 0 & 0 & $\begin{array}{l}\text { Hot rolled, pickled, \#1 } \\
\text { finish }\end{array}$ \\
\hline 329 & 106 & 7 & 0 & 0 & 37 & 37 & $\begin{array}{l}\text { Hot rolled, pickled, \#1 } \\
\text { finish }\end{array}$ \\
\hline
\end{tabular}


Table 2.14 Influence of Composition on Pitting Corrosion of Austenitic Stainless Steels in Low Velocity Seawater at Ambient Temperatures [46]

\begin{tabular}{|c|c|c|c|c|}
\hline $\begin{array}{c}\text { AISI } \\
\text { Type }\end{array}$ & $\begin{array}{c}\text { Duration of } \\
\text { Test, days }\end{array}$ & $\begin{array}{c}\text { Area of } \\
\text { Specimen, } \\
\text { sq in }\end{array}$ & $\begin{array}{c}\text { Velocity, } \\
\text { ft/sec }\end{array}$ & $\begin{array}{c}\text { Max Depth } \\
\text { of Pitting, } \\
\text { mils }\end{array}$ \\
\hline 302 & 483 & 18 & 3 & 31 \\
\hline 304 & 686 & 288 & $1-2$ & 134 \\
\hline 347 & 483 & 18 & 3 & 68 \\
\hline 316 & 483 & 18 & 3 & 20 \\
\hline 316 & 1920 & 288 & $1-2$ & 37 \\
\hline 310 & 989 & 288 & $1-2$ & 19 \\
\hline
\end{tabular}

Note: Test temperature not specified by authors but, based on seawater velocity, the tests were likely to have been near surface evaluations where the temperature would be in the range of $10-20^{\circ} \mathrm{C}$.

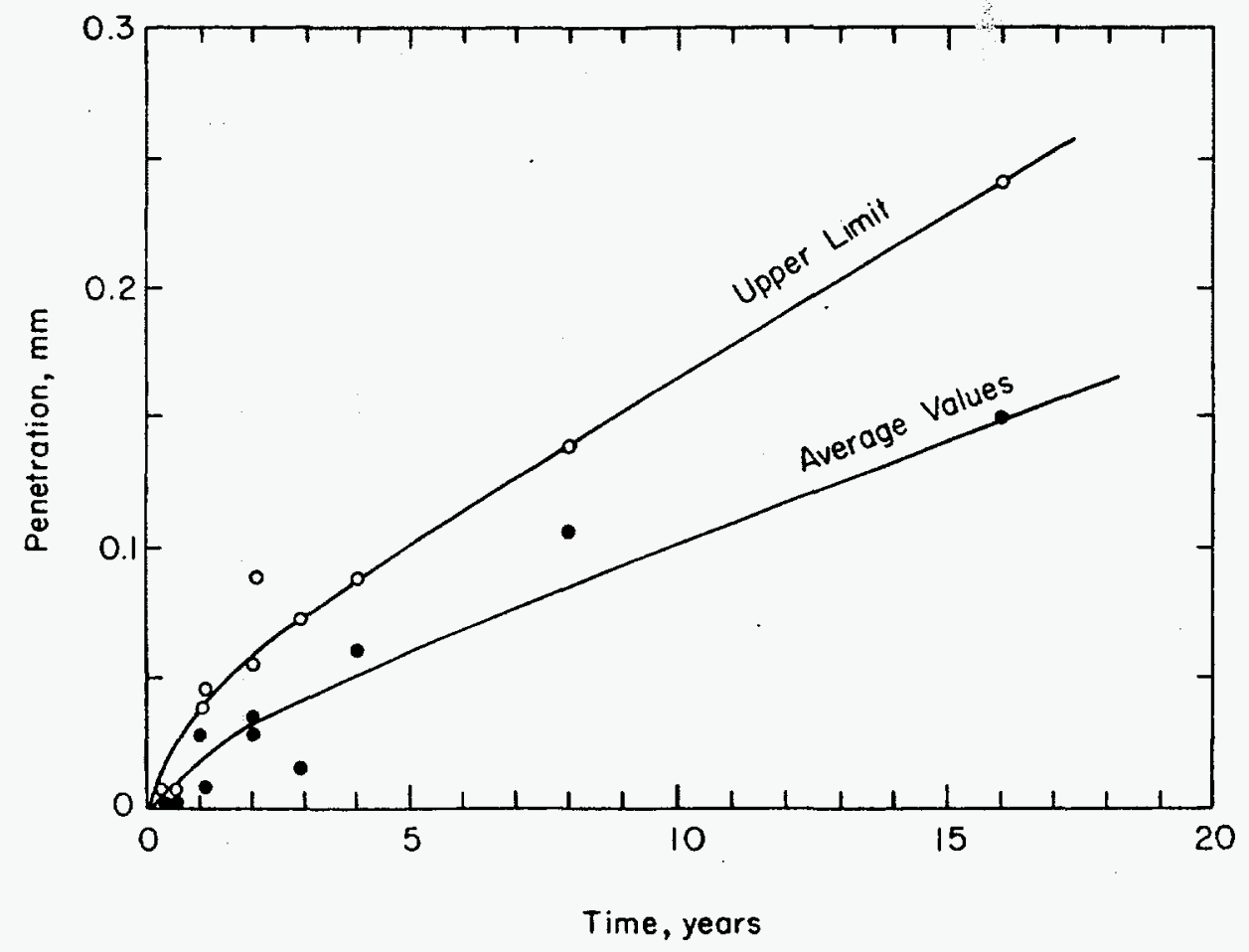

Figure 2.24 Effect of exposure time on the penetration of stainless steels as determined from weight-loss measurements [8]. 
Table 2.15 Corrosion Rates (mils/year) of Stainless Steel and Alloy $600^{(\mathrm{a})(\mathrm{b})}[35]$

\begin{tabular}{|c|c|c|c|c|c|c|}
\hline \multirow[b]{2}{*}{ Environment } & \multirow[b]{2}{*}{ Station } & \multirow{2}{*}{$\begin{array}{c}\text { Exposure } \\
\text { Duration Years }\end{array}$} & \multicolumn{2}{|c|}{ CRES 304 Stainless Steel } & \multicolumn{2}{|c|}{$\mathrm{Ni}-\mathrm{Cr}-\mathrm{Fe}$ Alloy 600} \\
\hline & & & Mean \pm S.D. & Range & Mean \pm S.D. & Range \\
\hline Flowing Seawater & $\begin{array}{l}\text { DOS-2 } \\
\text { DOS-2 } \\
\text { Test Stand } \\
\text { Test Stand } \\
\text { Test Stand } \\
\text { DOS-2 }\end{array}$ & $\begin{array}{l}0.8 \\
1.0 \\
1.0 \\
2.0 \\
3.0 \\
3.1\end{array}$ & $\begin{array}{l}0.0008 \pm 0.0004 \\
0.0032 \pm 0.0021 \\
0.042 \\
\text { Nil } \\
0.012 \\
0.0001 \pm 0.0001\end{array}$ & $\begin{array}{l}0.0005-0.0013 \\
0.0004-0.0050 \\
0.002-0.15 \\
-- \\
-- \\
0-0.0003\end{array}$ & $\begin{array}{l}0.0029 \pm 0.0014 \\
0.0015 \pm 0.0012 \\
0.0006 \pm 0.0004 \\
-- \\
-- \\
0.0001 \pm 0.0001\end{array}$ & $\begin{array}{l}0.0013-0.0047 \\
0.0004-0.0032 \\
0-0.0011 \\
-- \\
-- \\
0-0.0002\end{array}$ \\
\hline $\begin{array}{l}\text { Semi-stagnant } \\
\text { Seawater }\end{array}$ & $\begin{array}{l}\text { DOS-2 } \\
\text { DOS-2 }\end{array}$ & $\begin{array}{l}1.0 \\
3.1\end{array}$ & $\begin{array}{l}0.024 \pm 0.012 \\
\text { Nil }\end{array}$ & $\begin{array}{l}0.011-0.040 \\
--\end{array}$ & $\begin{array}{l}0.019 \pm 0.011 \\
\text { Nil }\end{array}$ & $\begin{array}{l}0.007-0.032 \\
--\end{array}$ \\
\hline Stagnant Seawater & $\begin{array}{l}\text { DOS-2 } \\
\text { DOS-2 }\end{array}$ & $\begin{array}{l}1.0 \\
3.1\end{array}$ & $\begin{array}{l}0.004+0.002 \\
\text { Nil }\end{array}$ & $\begin{array}{l}0.002-0.006 \\
--\end{array}$ & $\begin{array}{l}0.003 \pm 0.001 \\
\text { Nil }\end{array}$ & $\begin{array}{l}0.001-0.005 \\
--\end{array}$ \\
\hline Sediment & $\begin{array}{c}\text { DOS-2 } \\
\text { DOS-2 } \\
\text { Test Stand } \\
{ }^{(c)} \\
\text { DOS-2 }\end{array}$ & $\begin{array}{l}0.8 \\
1.0 \\
1.0 \\
3.1\end{array}$ & $\begin{array}{l}0.011 \pm 0.003 \\
0.0002^{(e)} \\
0.0063^{(e)} \\
0.0009^{(e)}\end{array}$ & $\begin{array}{l}0.0007-0.0015 \\
0-0.0006 \\
0.001-0.009 \\
0-0.004\end{array}$ & $\begin{array}{l}0.0031 \pm 0.0007^{(\mathrm{d})} \\
0.0008^{(\mathrm{e})} \\
0.0029^{(\mathrm{e})} \\
0.0001 \pm 0.0001\end{array}$ & $\begin{array}{l}0.0022-0.0036 \\
0-0.0031 \\
0-0.0048 \\
0-0.0001\end{array}$ \\
\hline
\end{tabular}

\section{NOTES:}

a. $1 \mathrm{mil} / \mathrm{y}=0.0254 \mathrm{~mm} / \mathrm{y}$

b. Corrosion rates are mean values of four specimens \pm standard deviation unless otherwise indicated. No standard deviation or range indicates value either not calculated or obtained from one specimen only. Range is based on four specimens unless otherwise indicated.

c. Corrosion test frame assembly was tipped over on top of sediment and not completely buried as planned.

d. Value based on three specimens.

e. Standard deviations were not calculated for these samples since the data did not reflect a normal distribution. 
Table 2.16 Seawater Crevice Corrosion Behavior of Austenitic Stainless Steels [10]

\begin{tabular}{|c|c|c|c|c|c|}
\hline \multirow[b]{2}{*}{ Type } & \multirow[b]{2}{*}{ Depth $^{(a)}$} & \multirow{2}{*}{$\begin{array}{c}\text { Exposure } \\
\text { Time, } \\
\text { days }\end{array}$} & \multicolumn{2}{|c|}{ Crevice Attack, mils } & \multirow{2}{*}{ Local Corrosion } \\
\hline & & & Water & Mud & \\
\hline 304 & $\begin{array}{l}2340 \\
5300\end{array}$ & $\begin{array}{l}197 \\
1064\end{array}$ & $\begin{array}{l}11 \\
21\end{array}$ & $\begin{array}{l}\text { Slight } \\
29\end{array}$ & $\begin{array}{l}\text { Edge, tunnel } \\
\text { None in water; tunnel in mud }\end{array}$ \\
\hline $304 \mathrm{~L}$ & $\begin{array}{l}2340 \\
5300\end{array}$ & $\begin{array}{l}197 \\
1064\end{array}$ & $\begin{array}{l}8 \\
27, \text { perforated }\end{array}$ & $\begin{array}{l}18 \\
0\end{array}$ & $\begin{array}{l}\text { Tunnel } \\
\text { Severe tunnel }\end{array}$ \\
\hline 316 & $\begin{array}{l}2340 \\
5300 \\
5640\end{array}$ & $\begin{array}{l}197 \\
1064 \\
123\end{array}$ & $\begin{array}{l}0 \\
21,12 \\
0\end{array}$ & $\begin{array}{l}0 \\
0 \\
0\end{array}$ & $\begin{array}{l}\text { None visible } \\
\text { None } \\
\text { Slight edge }\end{array}$ \\
\hline $316 \mathrm{~L}$ & $\begin{array}{l}2340 \\
5300 \\
5640\end{array}$ & $\begin{array}{l}197 \\
1064 \\
123\end{array}$ & $\begin{array}{l}18 \\
25,8 \\
\text { Slight }\end{array}$ & $\begin{array}{l}12 \\
20 \\
\text { Slight }\end{array}$ & $\begin{array}{l}\text { None visible } \\
\text { Ditto } \\
\text { " }\end{array}$ \\
\hline Alloy $20 \mathrm{Cb}$ & $\begin{array}{l}2340 \\
5300 \\
5640\end{array}$ & $\begin{array}{l}197 \\
1064 \\
123\end{array}$ & $\begin{array}{l}\text { Slight } \\
0 \\
0\end{array}$ & $\begin{array}{l}\text { Slight } \\
\overline{0}\end{array}$ & $\begin{array}{l}\text { None visible; attack at wall of bolt hole } \\
\text { None visible } \\
\text { Ditto }\end{array}$ \\
\hline
\end{tabular}

a. oxygen level at 2340 feet is $0.60 \mathrm{ppm}$; that at 5300 feet is about $1.70 \mathrm{ppm}$ 


\subsection{Corrosion of Titanium, Zirconium and their Alloys}

The corrosion of titanium and its alloys in chloride solutions is well documented $[20,31,49-52]$. The resistance arises from the formation of a thin highly-impervious oxide film that causes passivity. Corrosion rates are unaffected by variations in salinity, $\mathrm{pH}$, pressure, and biofouling at ocean locations studied, and are generally too low to measure accurately. Uniform corrosion rates of unalloyed titanium are reported to average about zero for tests lasting up to three years, and $0.016 \mathrm{mils} / \mathrm{y}(0.0004 \mathrm{~mm} / \mathrm{y})$ for tests lasting over $4.5 \mathrm{y}[31,52]$. Rates for alloyed titanium are similar $[20,31]$.

Figure 2.25 shows the results from a series of scoping tests to determine the conditions under which unalloyed titanium would be susceptible to crevice corrosion ảnd pitting in chloride environments. A wide range of temperatures was used to study thermal effects. It was found that for temperatures below $80^{\circ} \mathrm{C}\left(175^{\circ} \mathrm{F}\right)$ crevice attack could not occur regardless of solution $\mathrm{pH}$. For chloride levels equivalent to these for seawater, crevice attack would only occur for temperatures in excess of $130^{\circ} \mathrm{C}\left(266^{\circ} \mathrm{F}\right)$. In the case of pitting, there is a $\mathrm{pH}$ dependence and it occurs at lower temperatures as the $\mathrm{pH}$ is decreased. It is highly unlikely that titanium will suffer from pitting or crevice corrosion in a disposal environment.

Zirconium, like titanium-based materials, have long been known to have excellent corrosion resistance [53,54]. Zircaloy 1 and Zircaloy 2 are zirconium-based alloys containing small amounts of tin, iron, and chromium. Zircaloy 2 also contains nickel. Table 2.17 gives compositions for these alloys which were specifically developed for water-cooled nuclear reactor fuel cladding. One of the most relevant reports on Zircaloy corrosion in deep ocean environments was prepared by Smyrl and coworkers [55] who were developing high-level waste containers for ocean disposal. The studies were carried out using seawater/sediment mixtures contained in high pressure systems to simulate the deep ocean. Tables 2.18 and 2.19 show the results of their tests, including data for other non-Zircaloy materials. Note that Udimet is a nickel-based alloy.

The results, which were for tests lasting 9 months, confirm that the Zircaloys have exceptional resistance to uniform corrosion. At 4 and $25^{\circ} \mathrm{C}\left(40\right.$ and $78{ }^{\circ} \mathrm{F}$ ) the corrosion rates are only $0.0008-0.003$ mils $/ y\left(2-7 \times 10^{-5} \mathrm{~mm} / \mathrm{y}\right)$. These are orders of magnitude less than for stainless steel corrosion described above in Section 2.3.1. Clearly, the Zircaloy barriers will not fail early by uniform corrosion in seawater. For the limited data available in this study there does not appear to be any significant difference between the corrosion rate for seawater alone and that for corrosion in the presence of sediment.

Zirconium and Zircaloy are susceptible to embrittlement if hydrogen is allowed to enter the material under high temperatures [53]. It will eventually form hydrides that may cause embrittlement. Under deep ocean conditions, however, the amount of hydrogen available will be small so that this type of failure should not occur. 


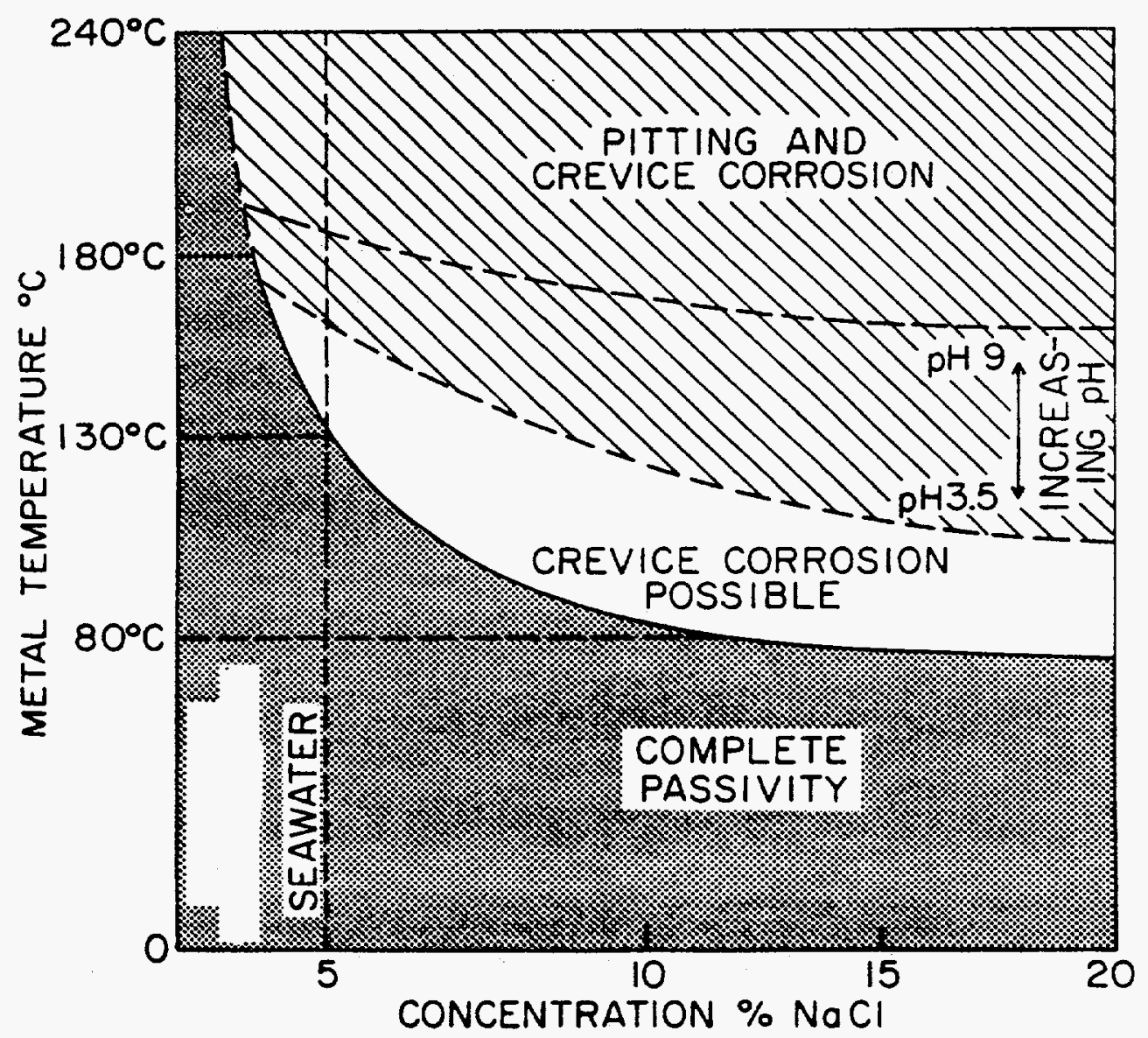

Figure 2.25 Influence of temperature, chloride content and $\mathrm{pH}$ value on crevice corrosion and pitting of unalloyed titanium [52]. 
Table 2.17 Compositions of Zircaloy 2 and Zircaloy 4

\begin{tabular}{|ccc|}
\hline & Zircaloy 2 & Zircaloy 4 \\
\hline $\mathrm{Sn}$ & $1.20-1.70$ & $1.20-1.70$ \\
$\mathrm{Fe}$ & $0.07-0.20$ & $0.18-0.24$ \\
$\mathrm{Cr}$ & $0.05-0.15$ & $0.07-0.13$ \\
$\mathrm{Ni}$ & $0.03-0.08$ & $<.007$ \\
$\mathrm{~N}$ & $<80 \mathrm{ppm}$ & $<80 \mathrm{ppm}$ \\
$\mathrm{O}$ & Spec. ${ }^{*}(1000-1500)$ & Spec. ${ }^{*}(900-1500)$ \\
$\mathrm{H}$ & $<25 \mathrm{ppm}$ & $<25 \mathrm{ppm}$ \\
$\mathrm{Zr}$ & Remainder & Remainder \\
\hline
\end{tabular}

* Specified when purchased 
Table 2.18 Corrosion Rate of Candidate Materials in Seawater and Sediments at $4{ }^{\circ} \mathrm{C}$, $55 \mathrm{MN} / \mathrm{m}^{2}(8000 \mathrm{psi})^{1}[55]$

\begin{tabular}{|l|c|c|}
\hline \multicolumn{1}{|c|}{ Material } & Weight Change $(0.001 \mathrm{gm})$ & Corrosion rate $(\mathrm{mm} / \mathrm{yr}) \times 10^{5}$ \\
\hline Titanium & $0(\mathrm{~S})^{2}$ & - \\
$\left(\right.$ area $\left.=22.7 \mathrm{~cm}^{2}\right)$ & $+1(\mathrm{M})^{3}$ & - \\
& $0(\mathrm{M})$ & -- \\
\hline Titanium $6 \% \mathrm{Al}, 4 \% \mathrm{~V}$ & $-5(\mathrm{~S})$ & 8 \\
$\left(\right.$ area $\left.=19.8 \mathrm{~cm}^{2}\right)$ & $-1(\mathrm{~S})$ & 1.5 \\
& $-4(\mathrm{M})$ & 11 \\
\hline Zircaloy-2 & $-7(\mathrm{M})$ & 1.8 \\
(area $\left.=23.2 \mathrm{~cm}^{2}\right)$ & $-2(\mathrm{~S})$ & - \\
& $+1(\mathrm{~S})$ & 1.8 \\
& $-2(\mathrm{M})$ & 1.8 \\
& $-2(\mathrm{M})$ & 5.3 \\
\hline Zircaloy-4 & $-6(\mathrm{M})$ & 3 \\
(area $\left.=21.2 \mathrm{~cm}^{2}\right)$ & $-3(\mathrm{~S})$ & 3.9 \\
& $-4(\mathrm{~S})$ & 3 \\
\hline Udimet-7004 & $-3(\mathrm{M})$ & -- \\
(area $\left.=12.76 \mathrm{~cm}^{2}\right)$ & $-3(\mathrm{M})$ & -- \\
& $0(\mathrm{~S})$ & -- \\
\hline
\end{tabular}

Note:

1. Nine month test

2. $S$ denotes in seawater

3. $\quad M$ denotes in seawater and sediments

4. Composition is $4 \% \mathrm{Al}, 4 \% \mathrm{Ti}, 5 \% \mathrm{Mo}, 15 \% \mathrm{Cr}, 15 \% \mathrm{Co}, 57 \% \mathrm{Ni}$ 
Table 2.19 Corrosion Rate of Candidate Materials in Seawater and Sediments at $25^{\circ} \mathrm{C}, 55$ $\mathrm{MN} / \mathrm{m}^{2}(8000 \mathrm{psi})^{1,2}[55]$

\begin{tabular}{|l|c|c|}
\hline \multicolumn{1}{|c|}{ Material } & Weight Change $(0.001 \mathrm{gm})$ & Corrosion rate $(\mathrm{mm} / \mathrm{yr}) \times 10^{5}$ \\
\hline Titanium & $-1(\mathrm{~S})^{3}$ & 1.3 \\
& $+1(\mathrm{~S})$ & -- \\
& $-1(\mathrm{M})^{4}$ & 1.3 \\
\hline Titanium 6\% Al, 4\% V & $+1(\mathrm{~S})$ & -- \\
& $+2(\mathrm{~S})$ & -- \\
& $+1(\mathrm{M})$ & -- \\
\hline Zircaloy-2 & $-6(\mathrm{~S})$ & 5.3 \\
& $-3(\mathrm{~S})$ & 2.7 \\
& $-3(\mathrm{~S})$ & 2.7 \\
& $-4(\mathrm{M})$ & 3.5 \\
& $-3(\mathrm{M})$ & 2.7 \\
\hline Zircaloy-4 & $-7(\mathrm{~S})$ & 6.8 \\
& $-2(\mathrm{M})$ & -- \\
\hline Udimet-700 & $0(\mathrm{M})$ & 3.5 \\
& $-3(\mathrm{~S})$ & -- \\
& $+1(\mathrm{~S})$ & 7 \\
\hline
\end{tabular}

Note:

1. Nine month test

2. Areas, notation same as Table 2.18

3. S denotes in seawater

4. $\quad \mathrm{M}$ denotes in seawater and sediment

5. Composition is $4 \% \mathrm{Al}, 4 \% \mathrm{Ti}, 5 \% \mathrm{Mo}, 15 \% \mathrm{Cr}, 15 \% \mathrm{Co}, 57 \% \mathrm{Ni}$ 


\subsection{Corrosion of Copper and Its Alloys}

Copper and copper alloys have a long and successful history in marine service. The first usage of copper was as antifouling sheathing on the hulls of ships and dates back to the late 1700's. Later, copper was used in the condenser tubes of steamships [56]. Today copper alloys are commonly used for the condenser tubes of power generating plants and ships. Much of the published data pertain to condenser type applications which are relatively high temperature high velocity water [57]. Most marine service copper is subjected to flowing seawater where corrosion resistance is excellent. In stagnant ocean water pitting and crevice corrosion can occur via ion concentration cells $[20,57]$.

The corrosion resistance of copper alloys is dependent upon the formation of a thin adherent film of corrosion products. The film in saltwater is mainly cuprous oxide through which oxygen must diffuse for corrosion to continue. Since the corrosion rate is dependent on oxygen diffusion through this film, the rate of general corrosion decreases with exposure time as the film thickens. Figure 2.26 shows this effect for the various classes of copper alloys at an ocean depth of 1830 meters [58]. In this figure, the copper and its alloys are broken down into four subsets: copper, brasses, bronzes, and $\mathrm{Cu}-\mathrm{Ni}$ alloys. The uniform corrosion rates for submerged conditions vary from $0.008 \mathrm{~mm} / \mathrm{y}$ to $0.05 \mathrm{~mm} / \mathrm{y}$ for copper $(0.13-0.02 \mathrm{avg}$.), $<0.0025 \mathrm{~mm} / \mathrm{y}$ to $0.13 \mathrm{~mm} / \mathrm{y}$ for brasses $(0.025-0.05 \mathrm{avg}$.), $0.0013 \mathrm{~mm} / \mathrm{y}$ to $0.10 \mathrm{~mm} / \mathrm{y}$ for bronzes $(0.003-0.025 \mathrm{avg}$.) and $<0.0025 \mathrm{~mm} / \mathrm{y}$ to $0.04 \mathrm{~mm} / \mathrm{y}$ for $\mathrm{Cu}-\mathrm{Ni}$ alloys $(<0.013 \mathrm{avg}$.) [20,31]. The most attractive in terms of corrosion are the 90-10 and 70-30 Cu-Ni alloys. Both maintain low corrosion rates over a broader range of conditions than other copper metals. Many of the brasses and bronzes are subject to de-(metal)ification under submerged ocean environments. Addition of parting inhibitors or lowering zinc content have proven useful in preventing de-(metal)-ification.

Hummer, et al. found copper corrosion to decrease to a 16 year corrosion rate of 0.005 $\mathrm{mm} / \mathrm{y}$ with a deepest pit of $1.5 \mathrm{~cm}$.[59]. Assuming a pitting rate of $0.1 \mathrm{~mm} / \mathrm{y}$ (pitting rates are generally higher during the first few years [20]) results in a copper thickness of $20 \mathrm{~mm}$ for a 200 year barrier lifetime. Most of the copper metals are expected to have similar pitting or crevice corrosion rates or have uniform rates approaching the same value.

The corrosion rates of copper metals will be affected by any changes in the properties or integrity of the corrosion product brought about by alloying, current velocity, oxygen content, temperature, and contamination (especially sulfur).

It is believed that the ionic and electronic conductance of the $\mathrm{Cu}_{2} \mathrm{O}$ film is responsible for changes in corrosion rates [57,60]. For corrosion to occur, copper ions and electrons must pass through the $\mathrm{Cu}_{2} \mathrm{O}$ film. When copper is alloyed with elements that can become incorporated into the $\mathrm{Cu}_{2} \mathrm{O}$ lattice, the ionic and electronic conductivities are changed. Cation vacancies which exist in unalloyed copper permit easy ionic diffusion and easy electron movement by a valence change mechanism [57]. When an alloying element is added, it can fill these lattice defects or substitute for $\mathrm{Cu}^{+}$. The ionic and/or electronic conductivity thereby decreases with a subsequent decrease in corrosion. This effect is evident in the $\mathrm{Cu}-\mathrm{Ni}$ alloys which do not pit in stagnant seawater (they were still, however, subject to crevice attack) [21]. 


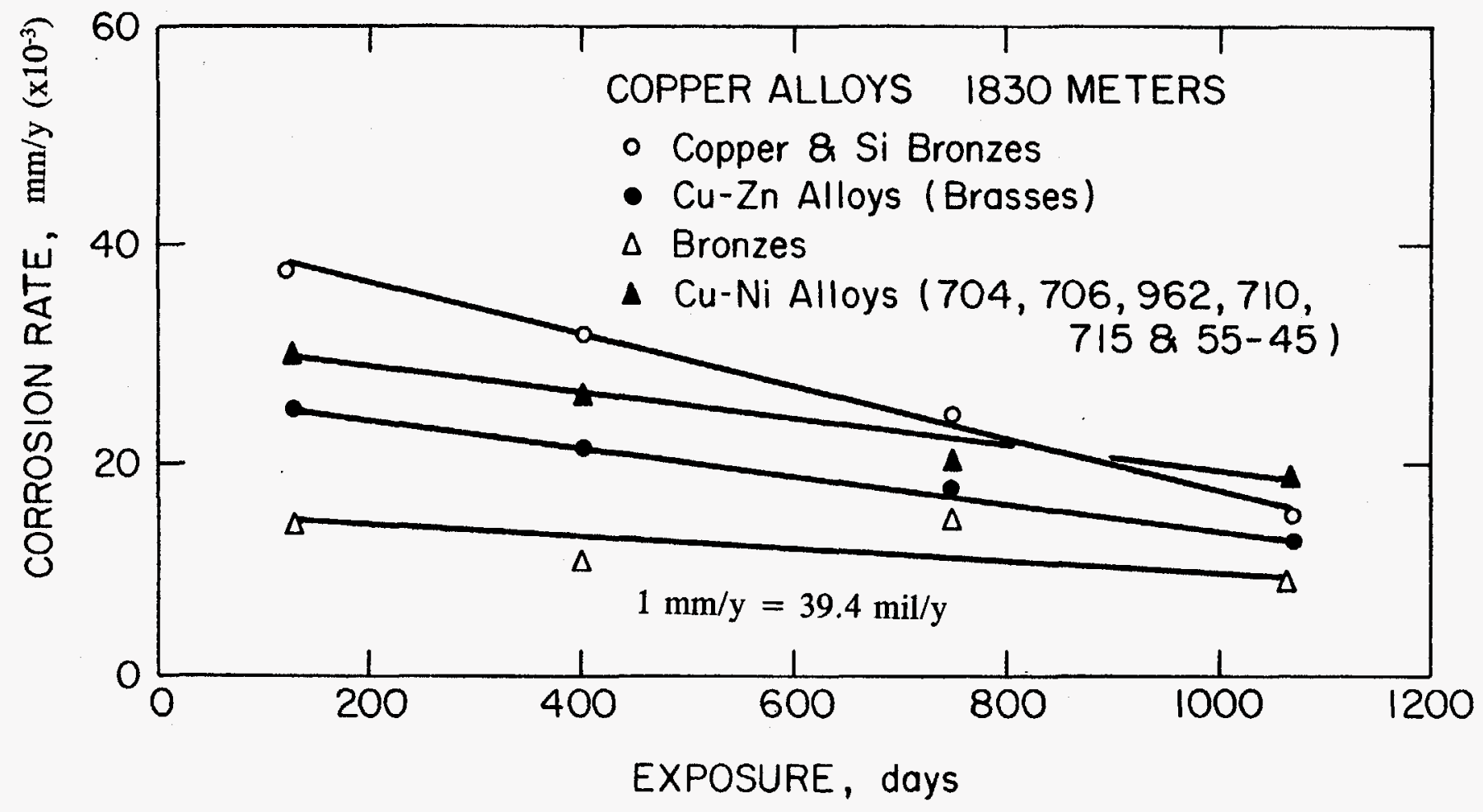

Figure 2.26 Effect of exposure time on corrosion of copper metals in an ocean environment [58]. 
Seawater velocity affects the corrosion of copper metals two ways. Sufficiently high velocities bring oxygen to the surface helping maintain the passive layer. High velocities can also strip the protective layer greatly increasing corrosion. Deep ocean currents $(0.03-0.3 \mathrm{~m} / \mathrm{s})$ should not greatly effect the corrosion of unalloyed copper [20]. Penetration rates at low deepsea flow velocities may increase greatly due to enhanced localized corrosion. As mentioned, pitting has been greatly decreased by alloying $(90-10 \mathrm{Cu}-\mathrm{Ni}, \mathrm{Al}$ bronze). Crevice corrosion, while present, is not as severe as for many other metals.

Oxygen greatly influences the corrosion rate on clean copper metal surfaces. Once a protective film has formed and oxygen must diffuse through, the effect of oxygen content is almost insignificant at ocean levels. Reinhart [31] reported corrosion of copper to be unaffected by oxygen content in the range 0.4 to $5.75 \mathrm{ppm}$. Rates for brasses and bronzes increased linearly (only slightly) with oxygen. In general rates for copper metals remain near constant over the range of ocean oxygen concentrations [31].

Increasing temperature increases the corrosion rates of copper metals. Under similar oxygen and current flows both uniform and localized corrosion will be expected to increase with temperature. Rates at deep ocean locations are reported to be similar from surface to bottom [20]. This is most likely due to velocity factors (pitting and crevice corrosion) in deep-sea environments overshadowing any temperature effects. While lower temperatures decrease corrosion, the low flow velocities initiate or increase localized corrosion.

Accelerated corrosion rates have been reported for sulfide contaminated waters [57,61,62]. MacDonald, et al. [62] reported sulfide pollution to reduce the passivity of $\mathrm{Cu}-\mathrm{Ni}$ alloys. Instead of forming $\mathrm{Cu}_{2} \mathrm{O}$ as the primary corrosion product some $\mathrm{Cu}_{2} \mathrm{O}$ formation occurred. Cuprous sulfide is a highly defective and conductive film. In the deep ocean, if sulfur reducing bacteria are present, there will be hydrogen sulfide present. This can lead to $\mathrm{Cu}_{2} \mathrm{~S}$ formation in the protective film. The presence of sulfur reducers in the sediment infers anaerobic conditions. One might expect low oxygen content to lead to low rates even with a non-protective film. Syrett, et al. [61] concluded the presence of sulfides, or polysulfides can turn even deaerated seawater into a comparatively corrosive medium.

\subsection{Corrosion of Nickel and Its Alloys}

Nickel and nickel alloys behave similarly to stainless steels (see Table 2.15). Corrosion resistance is dependent upon the formation and integrity of a thin passive film. In submerged marine applications, chloride ions can cause local breakdown leading to pitting and crevice corrosion. For the most part, nickel and nickel alloys show poor performance at ocean depths. The same factors which effect stainless steels will also cause changes in the corrosion of nickel alloys. The nickel-chromium alloys have low general corrosion rates but still are susceptible to crevice corrosion and pitting.

As mentioned, the corrosion resistance of nickel alloys is due to passive film formation. Alloying certain elements with nickel strengthens the resistance of this layer. The addition of chromium greatly reduces corrosion, as in Nichrome or Inconel 600 , but does not eliminate pitting or crevice corrosion. When molybdenum is added to nickel, crevice corrosion and pitting are nearly eliminated [20] as in Hastelloy B $(28 \% \mathrm{Mo}, 5 \% \mathrm{Fe})$, which is nearly immune 
to crevice corrosion in ocean waters. When both chromium and molybdenum are added, extreme resistance to corrosion results. This is the case for Hastelloy $\mathrm{C}$ and C-276 [63] ( $15 \%$ Mo, 3-4\% W, 4-7\% Fe)and Udimet $700(57 \% \mathrm{Ni}, 15 \% \mathrm{Cr}, 15 \% \mathrm{Co}, 5 \% \mathrm{Mo}, 4 \% \mathrm{Ti}$, $4 \% \mathrm{Al}$ [ [55]. These alloys are reported to be completely immune to local attack under ocean environments $[20,55,63,64]$. Corrosion is uniform and very low. Based on short-term corrosion experiments (9 months) and polarization studies, Udimet 700 is an excellent corrosion-resistant material in seawater. No long-term exposure studies for this alloy were uncovered during the literature search. Such studies are needed since crevice corrosion in many of the nickel alloys (i.e. Inconels) takes long periods (up to 3 years) to initiate. Once initiated, localized corrosion can be excessive during extended service.

Long-term rates for the Hastelloys are reported from 0.0002 to $0.0004 \mathrm{~mm} / \mathrm{y}[20,63]$. (Many reports only state $<0.004 \mathrm{~mm} / \mathrm{y}$ or no measurable rate due to insufficient measuring accuracy.) The $0.0004 \mathrm{~mm} / \mathrm{y}$ value is from 10 years exposure at ambient temperatures in low flow seawater and should be conservative for deep ocean sites. At this rate, a barrier thickness of only $0.08 \mathrm{~mm}$ ( 3.2 mils) is required for 200 years service.

\subsection{Corrosion of Aluminum and Its Alloys}

While aluminum alloys are finding increased use in marine environments, they are resistant only in well aerated waters or the atmosphere. Corrosion resistance is dependent upon maintenance of a passive oxide layer. Since the layer is readily attacked by chlorides in seawater, aluminum alloys are highly susceptible to pitting and crevice corrosion. Alloys of the 2000,4000 , and 7000 series are reported to have poor performance in marine environment [20]. Alloys in the $1000,3000,5000$ and 6000 series are found to have better resistance in seawater.

The 1000 series alloys contain at least $99 \%$ aluminum and are basically unalloyed aluminum. The 2000 series contain copper as the major alloying element. Copper contamination in water is known to enhance pitting in aluminum [65] and even the use of copper containing paints is ill-advised on aluminum alloys. Manganese $(>1 \%)$ is added to enhance strength in the 3000 series. Silicon is the main alloying element in the 4000 series. The 5000 series is perhaps the most resistant alloys without heat treatment. The 6000 series consist of Al-Mg-Si alloys of moderate high strength and good corrosion resistance. Some of the 7000 series develop the highest strengths of the commercial alloys. Alloying elements are zinc and magnesium but corrosion behavior is poor and erratic.

Average corrosion rates for aluminum alloys are $<0.08 \mathrm{~mm} / \mathrm{y}(<3.2 \mathrm{mil} / \mathrm{y})$ but $90-95 \%$ of this is due to local corrosion [20]. The pitting and crevice corrosion rates are therefore, extremely high. Local corrosion is also much more intense at deep-sea locations. One 5000 series alloy, 5052-0, which showed no crevice corrosion after 181 days at the surface, was corroded through $(\sim 1.7 \mathrm{~mm})$ in 123 days at an ocean depth of 1800 meters [31].

\subsection{Corrosion of Lead and Its Alloys}

Lead has been used as sheathing for submerged communications cables and has shown excellent performance [20]. Uniform corrosion rates of $0.008 \mathrm{~mm} / \mathrm{y}(0.32 \mathrm{mil} / \mathrm{y})$ for 16 years' 
exposure to $0.013 \mathrm{~mm} / \mathrm{y}(0.5 \mathrm{mil} / \mathrm{y})$ have been reported $[31,66,67]$. Some alloys were shown to have rates as high as $0.03 \mathrm{~mm} / \mathrm{y}(1.2 \mathrm{mil} / \mathrm{y})$. Boyd and Fink [20] found pitting under fouling organisms. They suggest that $\mathrm{H}_{2} \mathrm{~S}$ generation near the bottom of fouling layers may modify lead corrosion. Reinhart [31] reported no cases of pitting during deep ocean exposures of up to 3 years. Lead, therefore, appears to be a valuable barrier metal based on prior ocean service data.

\subsection{Conclusions on the Use of Metallic Barriers}

Metallic materials have traditionally been used as barrier materials for ocean disposal of low-level radioactive wastes. In particular, carbon steel containers have been extensively used because of their low cost, availability, and the relatively large volume of corrosion data for seawater service. Under deep ocean conditions, metallic materials will perform more satisfactorily compared to the near surface, because of the lower oxygen levels, and lower temperatures, an decreased potential for biofouling at depth. A summary of corrosion performance for the various classes of metallic materials is given below.

1. Carbon and low-alloy steels are susceptible to both uniform and localized attack in seawater. Failure of these materials will occur from local attack, such as pitting, in relatively short times (tens of years). Coatings will increase service life, but there are inadequate data to give accurate estimates of penetration time.

2. Stainless steels have uniform corrosion rates that are several orders of magnitude less than those for carbon and low-alloy steels, depending on the corrosion environment. However, pitting is still a factor to contend with. The addition of molybdenum (such as in Type 316 stainless steel) is a means of reducing but not eliminating, this type of attack.

3. Nickel, titanium, zirconium and their alloys are among the more corrosion resistant materials in seawater service. Uniform corrosion rates are often lower than for stainless steels, but they are more expensive to use. Localized corrosion in these materials is also less than for stainless steels.

4. Copper and aluminum-based materials suffer from pitting and crevice corrosion in seawater and this must be considered if they are to be used as barrier materials.

5. Lead and its alloys have been used as sheathing materials for submerged electrical cables for many years. Alloying the lead is effective in reducing uniform attack. Pitting does not appear to be a significant problem in seawater, based in deep ocean exposures for several years.

6. Galvanic attack will only be a problem if barriers of different metals or alloys are in contact. For waste containers that are segregated into specific types of materials, galvanic attack will not occur. 


\section{CONCRETES}

\subsection{Hydraulic Cement Concrete}

A hydraulic cement is by definition a material that upon mixing with water sets into a hardened solid mass. If particles or aggregate are incorporated into the mixture, a class of structural materials called hydraulic cement concretes is formed. Cement concrete is a possible barrier material where slow release of contaminants to the biosphere is acceptable. Under a complete containment policy, all cement concretes would be unacceptable due to their permeability to seawater. Seawater has been shown to permeate through even low porosity concretes $(10 \mathrm{~cm}$. wall thickness) in less than six months [68]. Even though unmodified concretes alone cannot meet total containment requirements, a discussion of the failure mechanisms for this material is useful.

For marine applications the most important concretes are made from portland, high alumina, portland-pozzolan, and portland-blast furnace slag cements. Portland cements are the most commonly used hydraulic cement and consist of eight types (ASTM), I, IA, II, IIA, III, IIIA, IV, and V [69]. The main constituents are $\mathrm{CaO}(60-65 \%), \mathrm{SiO}_{2}(20-25 \%), \mathrm{Fe}_{3} \mathrm{O}_{3}$ and $\mathrm{Al}_{2} \mathrm{O}_{3}$ (combined 7-12\%). Type $\mathrm{I}$ is a general use cement with no special corrosion resistance properties. This is the most commonly used portland cement. Type II is a moderately sulfateresistant cement with moderate heat of hydration. Its sulfate resistance is achieved by restricting tricalcium aluminate content to less than eight percent. Type III is an "earlystrength" cement with no special corrosion resistance properties. It is used in structures which must be used soon after completion. Type IV (low heat of hydration) is used in massive structures (i.e., dams) where excessive heat build-up could occur. Type $V$ is for higher-sulfate resistance and is preferred for seawater applications.

Sulfate resistance is obtained by restricting tricalcium aluminate content to less than five percent. Types IA, IIA, and IIIA are air entrained cements and are useful in areas subject to freezing and thawing. Other properties of these cements are the same as for Types I, II, and III.

High-alumina cements consist primarily of calcium aluminates [70]. Such cements have high early strength and good resistance to sulfate attack. One drawback to alumina cements is the permanent strength losses that can occur at elevated temperatures when moisture is present $[69,70]$.

Portland-blast furnace slag cement contains $25-65 \%$ (w/w) finely divided blast furnace slag, and $75-35 \%$ portland cement [69]. This cement has good to excellent service in marine environments depending upon the amount and type of portland cement used. Blast furnace slags are non-metallic by-products from the smelting of iron ores in blast furnaces. They consist mainly of calcium silicates and calcium aluminosilicates.

Portland-pozzolan cements are a mixture of pozzolan and portland or portland-blast furnace slag cement. Pozzolans are siliceous or siliceous and aluminous materials [69] such as trass, fly ash, boiler slag and volcanic ash. The pozzolan constitutes $15-40 \%(w / w)$ of the cement. These cements have good to excellent chemical resistance to seawater $[69,70]$. 


\subsubsection{Concrete Degradation}

Concretes for ocean disposal are subject to failure caused by sulfate attack, mishandling, cracking due to pressure in the ocean, and by marine borers [70-74]. Ocean waters contain $\sim 2800 \mathrm{ppm}$ sulfates, which is sufficient for attack of the cement phase to occur $[68,75]$. Cracking during descent has been demonstrated by Seki et al.[70]. Attack by marine borers on concrete is well documented [70,76]. At depths greater than $4000 \mathrm{~m}$ marine borers are present but in much less numbers than shallow waters [74]. The use of granite aggregate or copper containing additives in the concrete eliminates or reduces borer attack to insignificant levels. Since borer attack is minimal in the deep sea and treatable, no further discussion will be given. The remainder of this section will deal with sulfate attack and cracking failures.

\subsubsection{Sulfate Attack}

Cements in solutions containing sulfate are attacked by two main mechanisms. The first involves sulfate-induced formation of calcium sulfoaluminate hydrates (ettringite) which can lead to cracking, and the second is surface softening due to gypsum formation.

Sulfoaluminate formation may occur, to a destructive extent, in cements containing $>5 \%$ tricalcium aluminate $\left(3 \mathrm{CaO} \cdot \mathrm{Al}_{2} \mathrm{O}_{3}\right)$. In the presence of $\mathrm{Ca}(\mathrm{OH})_{2}$ (formed during cement hardening) sulfates react with hydrated tricalcium aluminate to form ettringite. Normally the ettringite readily hydrates and expands causing the cement to crack. In seawater, however, the ettringite does not cause the same degree of expansion damage observed in fresh waters and soils. This has been attributed to the increased solubility of ettringite in chloride solutions [77]. Ettringite formation has seldom been shown to be the sole cause of cracking in offshore structures [71].

By reducing the tricalcium aluminate content of cements to less than $5 \%$ deterioration of concrete by sulfates is greatly reduced. For this reason portland type $\mathrm{V}$ cement shows good sulfate resistance. In the portland-pozzolan and portland-blast furnace slag cements replacement of some of the portland cement with pozzolan or slag reduces the tricalcium aluminate content of the final concrete. By additionally using a portland type $\mathrm{V}$ cement in portland-pozzolan or slag cements excellent sulfoaluminate resistance occurs. In the high alumina cements, sulfate resistance is due to the alumina being present as monocalcium aluminate hydrate rather than the tricalcium aluminate. The monocalcium aluminate is immune to sulfate attack [70,77]. The alumina cements are vulnerable to temperature and moisture effects. Hardening in the presence of excess moisture at temperatures $>20^{\circ} \mathrm{C}$ can cause the monocalcium aluminate to convert to the tricalcium aluminate with a corresponding decrease in sulfate resistance $[70,77]$. Careful manufacturing and storing of concretes made from high alumina cements is needed to maintain sulfate resistance.

In the second type of sulfate attack magnesium sulfate $\left(\mathrm{MgSO}_{4}\right)$ reacts with calcium hydroxide $\left[\mathrm{Ca}(\mathrm{OH})_{2}\right]$ as [17]:

$$
\mathrm{Ca}(\mathrm{OH})_{2}+\mathrm{MgSO}_{4} \cdot 7 \mathrm{H}_{2} \mathrm{O} \rightarrow \mathrm{Mg}(\mathrm{OH})_{2}+\mathrm{CaSO}_{4} \cdot 2 \mathrm{H}_{2} \mathrm{O}+5 \mathrm{H}_{2} \mathrm{O}
$$


This reaction removes $\mathrm{Ca}(\mathrm{OH})_{2}$ from the hardened cement phase and precipitates $\mathrm{Mg}(\mathrm{OH})_{2}$ as a soft white layer on the concrete. By reducing the $\mathrm{Ca}(\mathrm{OH})_{2}$ content originally in the concrete better resistance to $\mathrm{MgSO}_{4}$ occurs. Lower $\mathrm{Ca}(\mathrm{OH})_{2}$ content accounts for the excellent resistance to this attack by high alumina cements and portland-pozzolan and portland-slag cements.

\subsubsection{Permeability Effects on Concrete Degradation}

While changing the constituents and/or proportions of the cement used in making concretes can greatly increase seawater resistance, permeability is considered by many researchers to be the most important factor affecting durability [68,71]. Many long-term studies have attributed low porosity to long-term durability. Mehta and Haynes reported dense concrete blocks (some of high tricalcium aluminate content) to be in excellent condition after 67 years exposure to shallow seawater [78]. Porous concretes from the same investigation showed surface softening and general deterioration. Fluss and Gorman reported on 46 year old concrete made from dense $\left(395 \mathrm{~kg} / \mathrm{m}^{3}\right)$ Type I portland cement [79]. These concretes were found to be in good condition.

Most recommendations for seawater use recommend a minimum cement content of 350 $\mathrm{kg} / \mathrm{m}^{3}$ and a water/cement ratio of 0.40 to $0.45[70,77]$. Mehta states that such concrete, along with good concreting practice (i.e., vibration compaction), will result in a low permeability [71]. Higher water/cement ratios greatly increase concrete porosity as seen in Figure 3.1 [80]. In contrast to fresh water permeability, Haynes found saltwater permeabilities decreased with time [81]. One possible explanation given was the formation of crystals or precipitation of sulfate reaction products in the pore network which reduces permeability.

Colombo et al. [2] retrieved a waste package from the ocean floor after about 15 years exposure. They concluded the cement waste form (radius $25 \mathrm{~cm}$ ) would not completely dissolve for at least 300 years. The concrete used was not of high quality. Careful selection and fabrication of concretes can yield a product, which at reasonable thicknesses, will resist chemical deterioration for hundreds of years. Use of quality portland (Type V)-pozzolan or slag cement or high alumina cement at minimum concrete contents of $350 \mathrm{~kg} / \mathrm{m}^{3}$ and $0.40-0.45$ water/cement ratios will also aid in excellent sulfate resistance. Fabrication could include vibration compaction and good general concreting practices to assure low permeability. Aggregate should be granite to minimize marine borer damage.

\subsubsection{Mechanical Failure}

This discussion will deal only with barrier cracking due to pressure increases during descent to the ocean floor, and will not consider cracking caused by faulty manufacturing procedures or accidental dropping prior to emplacement at the ocean disposal site. 


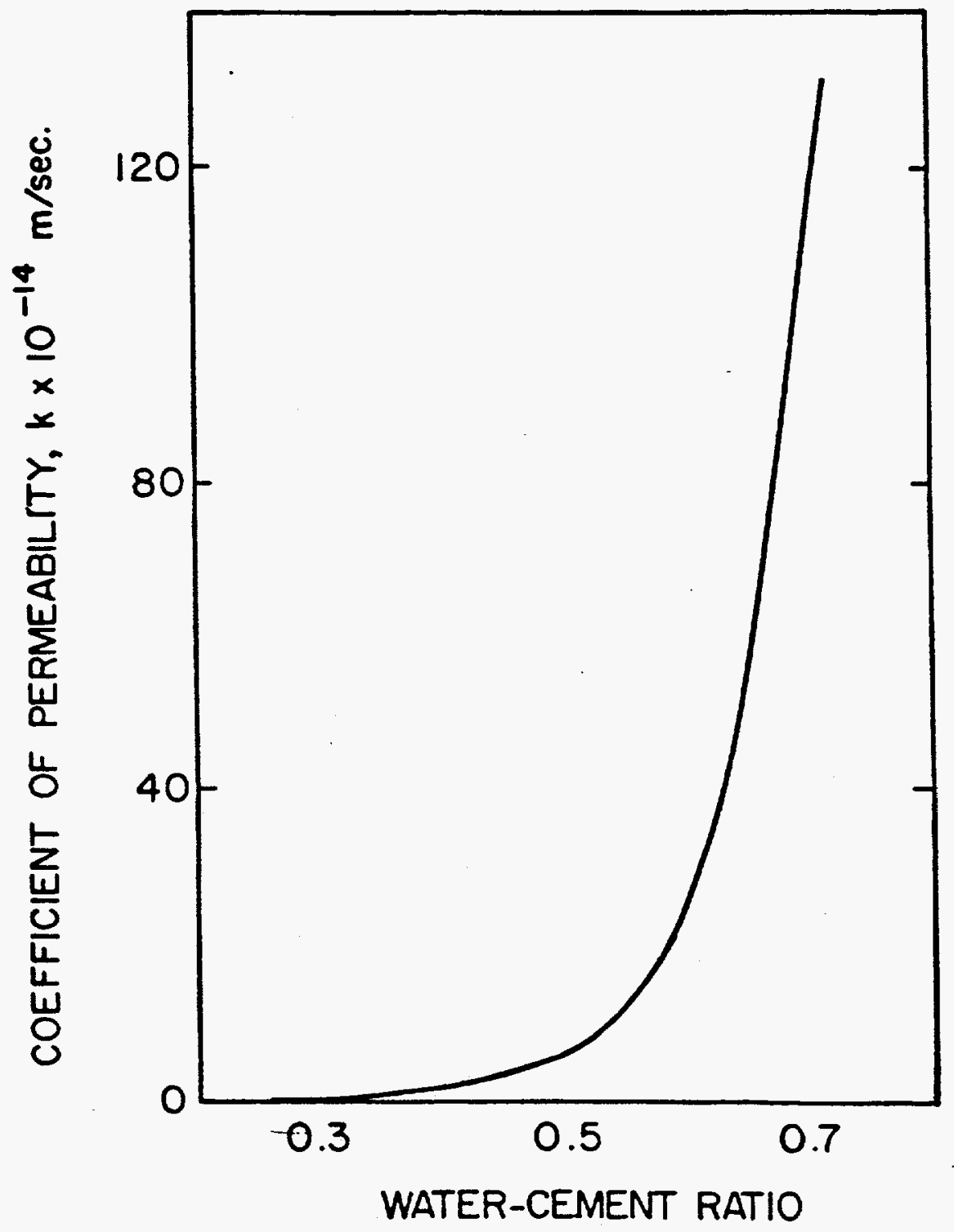

Figure 3.1 Effect of water/cement ratio on permeability [80]. 
Seki et al. [72] found that concretes may crack when rapidly pressurized. The rate of pressurization used in their work was equivalent to free fall descent of a waste package to the ocean floor. Two cements were used, normal portland and a blast furnace slag type. All concretes had uniaxial strengths exceeding $150 \mathrm{~kg} / \mathrm{cm}^{2}(2133 \mathrm{psi})$ which is sufficient to withstand $500 \mathrm{~kg} / \mathrm{cm}^{2}(7100 \mathrm{psi})$ hydrostatic pressures [72]. Concretes were exposed with and without protection by metal drums. For completely sealed drums, no cracking occurred; for all exposed concrete, surface cracking was evident by visual inspection. The authors concluded that rapid permeation of water into the concrete caused the cracking. To show this, some concretes were pressurized at slower rates and other concretes sealed with coal tar epoxy resin paint to slow permeation when rapidly pressurized. In both cases no cracking occurred. Not all cements may fail this way but rapid-pressure testing of any concrete barrier is important.

\subsubsection{Failure of Reinforced Concrete}

Thus far failure mechanisms have been discussed for concrete alone. Reinforced concrete is often used for added strength. The reinforcing medium is generally low-alloy steel bar or meshing. If corrosion of the steel occurs, cracking and spalling of the concrete can result $[70,77,82]$ Cracking occurs as a result of corrosion products building up at the steel/concrete interface, since the corrosion products are more voluminous than the original metal. This causes high tensile stresses to form in the concrete.

Initially, steel in the concrete will be contacted by seawater in the concrete pores. This pore water is very basic, $\mathrm{pH} 10$ to 13 , and provides a protective environment for the steel [78]. Under highly basic conditions steels form a virtually impervious oxide coating. Chloride ions in seawater can eventually break down this coating, allowing slow corrosion to occur. As this corrosion continues and metal chlorides are formed, a slow decrease in the $\mathrm{pH}$ in the pore waters accelerates the rate of corrosion and encourages cracking of the concrete.

Most investigations of reinforcement steel corrosion are from shallow water or tidal zones. Both good and bad durability have been seen. The general opinion is that the thickness of concrete cover over the steel determines the speed of corrosion [71,77]. Thin covers allow aggressive ions to easily reach the steel, initiating corrosion. Obviously, a less porous concrete is preferred since less seawater infiltration would occur. At deep ocean sites seawater penetration into concrete is expected to be much faster than at shallow depth. Reinforcements may be expected to corrode more rapidly. This was not evidenced in a cement waste form retrieved from the Atlantic $2800 \mathrm{~m}$ dump site, which showed no corrosion of the reinforcement mesh after about 15 years [2]. A large amount of research is being performed on coating the steel before placement in the concrete $[83,84]$. Zinc and epoxy coatings have been used to reduce corrosion of the reinforcing with mixed results. More long-term, deep ocean studies on corrosion of embedded steels is needed to determine life expectancies of reinforced concrete in the ocean.

\subsection{Polymer-Impregnated Concretes (PIC)}

The high permeability of hydraulic cement concrete barriers allows seawater to contact the waste form in a short period. One way to eliminate this problem is by impregnating the concrete with a monomer followed by polymerization. The polymer seals the pore networks 
in the concrete and gives a high degree of impermeability towards polar molecules such as water. With proper selection of monomer and manufacturing (degree of cross-linking, polymer loading, etc.) permeabilities can be reduced to insignificant levels [85].

A material similar to PIC is polymer concrete (PC). This differs from PIC in not being made by an impregnation process. Concrete is defined as an aggregate held together with a binder [86]. The binder does not have to be hydraulic cement. Concretes have been made by binding aggregates such as sand, gravel, and even crushed glass with a polymer. Polymer-glass concrete, developed at Brookhaven National Laboratory (BNL), has been successfully used as sewer pipe in a demonstration project in Huntington, NY [87]. Since the properties of concern for ocean disposal (permeability, chemical resistance, etc.) are similar for PIC and PC, conclusions for PIC will also pertain to polymer concretes. Since there is relatively little information on $\mathrm{PC}$, it will not be addressed further in this report.

In 1967 the U.S. Atomic Energy Commission and the Department of the Interior funded a joint research program carried out at BNL and the U.S. Bureau of Reclamation at Denver. The long-term goal was developing a new building material using cement concrete and polymers. The applicability of polymer-concrete composites to marine use was immediately recognized by the Naval Civil Engineering Laboratory (NCEL). Cooperative experiments on concrete hulls were carried out between NCEL and BNL. Additionally, NCEL successfully used PIC spheres to contain delicate instrumentation at extreme depths which, when in plain concrete spheres, had been water damaged. Present use and research of PIC has become worldwide and highly varied. PIC is used for long-term durable repairs of marine used concrete, in chemically resistant floors, vats, and reactors in industry, for highway repairs, in desalination plants and a wide range of other uses $[28,86,88]$.

\subsubsection{Properties of PIC}

Typical PIC is formed by taking moist, cured ( 28 days) concrete and drying to remove the $-3 \%$ free water. The concrete is then evacuated in a vessel to a pressure of a few inches of mercury. Liquid monomer is introduced and the vessel is slightly pressurized (up to 25 psi). The rate of monomer permeation through the concrete depends upon monomer viscosity, concrete thickness, and the overpressure. Typical monomers used in PIC include methyl methacrylate, styrene, and acrylonitrile. The monomer-soaked concrete is then subjected to polymerization by gamma radiation, heat, or chemical means (catalyst and promoters would be added prior to impregnation). The resultant composite not only has increased impermeability to water but virtually every other desirable property is greatly improved. Increases of nearly 300 percent in tensile and compressive strengths were observed for polymethacrylate-PIC [85]. Chemical resistance and durability in sulfates, acids, and alkalis are also greatly enhanced $[85,88]$. This chemical resistance can be further improved by the addition of cross-linking agents such as trimethylolpropane trimethacrylate (TMPTMA).

Because of the strength, resistance, and durability of PIC, the Japanese have aggressively pursued development of a PIC container for low-level waste disposal $[89,90]$. Japan has also conducted research on the use of PIC containers for ocean disposal [89]. Initially testing was performed on plain PIC containers. These were found to fail certain impact tests required for land transportation. Cracking of the PIC matrix occurred due to the brittle 
nature of the PIC used. Using steel fiber reinforced concrete, a new PIC barrier was developed and designated SFPIC. This container appears to satisfy transport regulations on integrity. SFPIC has resisted $5 \% \mathrm{MgSO}_{4}$ for 7 months and seawater for 440 days [90]. It has increased resistance to freeze-thaw-cycling, $2 \% \mathrm{H}_{2} \mathrm{SO}_{4}$, and fire [90]. Test containers have withstood short-term hydrostatic pressures at $5000 \mathrm{~m}$ in the ocean with no cracking or adverse effects [89].

Factors affecting the durability of plain concrete in seawater also affect PIC but to a greatly reduced extent. The chemical resistance of PIC is directly related to polymer loading in the concrete [85]. The greater the amount of polymer used, the higher the resistance of the resulting PIC. Maximum loading and resistance occurs near $7 \% \mathrm{w} / \mathrm{w}$ polymer. Incomplete drying will decrease the maximum loading achievable and hence the resistance decreases. In addition to deterioration of the concrete phase, the polymer matrix may be subject to degradation in the deep ocean. However, plastics oxidize very slowly at ocean sites and other chemical attacks will be insignificant.

Biodegradation has been observed for many plastics. Muroaka [74] exposed polymethylmethacrylate, polystyrene, polyesters, and an assortment of other plastics at $\sim 1800$ $\mathrm{m}$ for up to 3 years to determine biological attack. Borer damage to the polymers used in PIC was superficial (0.4-0.8 $\mathrm{mm}$ deep) and in most cases limited to areas baited with wood to attract borers. At depths $>4000 \mathrm{~m}$ without baiting, borer attack in PIC polymers should be virtually non-existent.

Available data on PIC suggests that a relatively thin $(2-8 \mathrm{~cm})$ barrier will provide a marine service life in excess of $200 \mathrm{y}$.

\subsection{Conclusions on the Use of Concrete-Based Barriers}

1. Unmodified cement concrete has limitations as a barrier material since all cements are, to some degree, permeable. Concrete, of low thickness, would allow seawater to contact the leachable waste form shortly after disposal. Deterioration of concrete in seawater occurs mainly by sulfate attack. By using alternate concretes, long-term durability is achievable. Improved concrete has very low tricalcium aluminate contents, low $\mathrm{Ca}(\mathrm{OH})_{2}$, a water/cement ratio of 0.40 to 0.45 , and is fabricated using good concreting methods, such as vibration compaction.

2. Cracking of some concretes during descent in the ocean may occur but can be minimized by applying a thin waterproof coating. Reinforced concretes may crack or spall due to corrosion of the embedded steel.

3. Polymer impregnated concrete can have the chemical, permeation and biological resistance to provide extended service in the deep ocean. Resistance depends mostly on the amount of polymer loading in the concrete. For superior resistance, maximum loading $(\sim 7 \% \mathrm{w} / \mathrm{w})$ of polymer have been used.

4. Due to cracking, plain PIC may not pass DOT transport requirements. However, with steel fiber reinforcement, PIC concretes are less susceptible to impact damage. 


\section{PLASTICS}

Plastics are a relatively new development, as so few long-term marine studies have been conducted. In general, good corrosion resistance in seawater is observed. The main degradation process of plastics in seawater is biological attack (marine borers). Muraoka [74] and Connolly [91,92] reported on a large number of plastics exposed to marine borers. Every plastic tested by Muraoka and most tested by Connolly were attacked. The typical damage was, however, superficial surface indents $\sim 3-4 \mathrm{~mm}$ in diameter and $1-2 \mathrm{~mm}$ in depth (although Connolly reported some PVC to be attacked up to $18 \mathrm{~mm}$ deep). Many of these plastics were only attacked under wood baits used to attract the borers.

The above studies typically involved common plastics such as nylon, teflon, polyethylene, etc., which are not as technologically sophisticated as more modern plastics. This is evident in work by Connolly et al. [92], in which polyethylene was observed to crack due to oxidation after only six years exposure. Oxidation-resistant polyethylenes exist now which were not available or fully developed at the beginning of their tests. With the proper manufacturing (crosslinking, additives, etc.) it is possible to select a polyethylene with muchimproved properties.

Newer more promising materials are constantly being developed by industry. They include plastics that are reinforced by fibers made from steel, boron, graphite, or glass. Before they can be qualified as seawater barrier materials they will need to be exposed to prototypic ocean disposal conditions for extended periods to assess their resistance to degradation and failure.

\subsection{Failure Mechanisms of Plastics}

\subsubsection{Biological Degradation}

The main failure for plastics in seawater was previously stated to be marine borer attack. Borers are one of the few species found below 4000 meters, although their numbers are greatly reduced from those found in warm shallow waters. Since borers dwell on or near the seabed, most attacks occur below one meter from the bottom [93]. Both Connolly [91] and Muraoka [74] consider plastic with smooth or waxy surfaces, like polyethylene, to be among the most resistant to borer penetration.

\subsubsection{Chemical Attack}

Most plastics are chemically resistant to seawater. Oxidation occurs, but is normally very slow especially for the newer plastics and at cooler deep-sea temperatures. Chloride ions, at the $\mathrm{pH}$ of ocean waters, do not generally attack plastics. The one chemical attack that may occur to plastics is solvation. Plastics may swell or soften and, in extreme cases, breaking of chemical bonds may occur in the presence of organic solvents [94]. The solvents would have to be fairly concentrated and could only come from the free standing liquid in the waste form. Since the amount of free standing liquid is small, and this liquid is not expected to be concentrated in organic solvents, little solvation should occur. Low temperatures decrease the amount and rate of solvation [94]. Solvation will probably only be a minor concern and will 
occur most during the land storage period where temperatures are considerably higher than the $2-4^{\circ} \mathrm{C}$ found in deep-sea waters. Since this problem is internal rather than external, it can be prevented by administrative controls on the composition of the waste form.

\subsubsection{Mechanical Failure}

Plastics are highly variable in mechanical characteristics. Some very high strength composites exist while other plastics are extremely weak. Both very brittle and very pliable plastics exist. Impact and drop testing of any plastic is a crucial point in container assessment. Many plastics also change mechanical properties drastically with temperature. Embrittlement can occur at low temperatures destroying much of the impact resistance a plastic may have had. Therefore, plastics should not only be tested at ambient temperatures but also near $0^{\circ} \mathrm{C}$ to simulate conditions found in the deep ocean.

Many plastics also contain plasticizer additives to enhance the elongation-at-failure. Plasticizers can, however, evaporate or leach out of the plastic with time, making the plastic more brittle. Long-term studies of plastics containing plasticizer additives would be desirable to check for possible losses in elongation.

\subsection{High Density Polyethylene}

High density polyethylene (HDPE) is an approved high integrity container material for low-level wastes in South Carolina [95]. Polyethylene has been standard for use as a solidification medium for wastes [96]. Work by Soo and coworkers has shown that HDPE is very resistant to chemical attack and to gamma irradiation at moderate doses [97-99].

Oxidation is one important mechanism that may cause losses in elongation-at-failure. It was estimated that $12 \mathrm{~mm}$ thick HDPE waste containers would suffer $10-11 \%$ oxidation in 300 years at land-disposal temperatures [94]. Under deep ocean disposal conditions, where temperatures and oxygen levels are lower, much less oxidation would be expected. Nevertheless, Connolly and coworkers did observe cracking of polyethylene in deep ocean environments after six years [92]. Additional studies would be able to more accurately quantify the behavior of newer types of HDPE under ocean disposal conditions.

Another consideration for HDPE barriers is that the material is less dense than water $(\sim 0.95 \mathrm{gm} / \mathrm{cc})$. If the barrier becomes fragmented, parts will float to the surface at the disposal site. This could be avoided if heavy reinforcing materials are molded into the plastic, or if the HDPE is used as an internal barrier that is enclosed by a high-integrity external enclosure. 


\subsection{Conclusions on the Use of Polymeric Barriers}

Many plastics (existing or being developed) may have adequate barrier properties for seawater service. Plastics technology is a rapidly developing area and improvements in mechanical and corrosion behavior occur continuously. For any specific plastic, several considerations must be addressed:

a. Degree of biodegradation, especially by marine borers.

b. Chemical attack by solvents, oxygen and chlorides.

c. Mechanical properties, in particular, impact resistance.

d. Resurfacing of waste package components after long periods due to the low densities of plastics.

High density polyethylene appears to be a candidate barrier material provided that its low-density $(0.95 \mathrm{gm} / \mathrm{cc})$ does not cause a barrier to float. 


\section{OTHER BARRIER MATERIALS}

\subsection{Bitumen}

Bitumen is a petroleum product. It is being used both as a barrier material and a waste solidification agent by European agencies [100]. Bitumen is permeable to water and, at room temperature, is somewhat pliable. At the $2-4^{\circ} \mathrm{C}$ temperatures of deep ocean bottom waters, bitumen will become harder and brittle. It may also swell upon extended exposure to water [100]. Some very slow oxidation can be expected in seawater which may eventually lead to cracking. Bitumen can be used as a thin waterproofing coating to prevent cracking of cement concretes caused by rapid water permeation during descent and can retard (short term) but not prevent permeation once the package is on the ocean floor.

\subsection{Glass}

Many glasses are highly resistant to seawater and chemicals. The main problem with glass is impact resistance and thermal expansion. This can cause shattering of the glass due to temperature decreases during descent. Glass may be useful as a component in a multibarrier container where it can be protected from impact damage, provided it has sufficiently low thermal expansivity.

\subsection{Paints and Coatings}

Paints and coatings (epoxies, coal tar resins, etc.) are usually applied to metals to delay corrosion. For ocean disposal applications they offer some potential for increasing the time to onset of corrosion of the metal, but the coatings will eventually fail. If there are scratches or imperfections in the coating these could be the sites for fast local attack.

\subsection{Conclusions on the Use of Other Barrier Materials}

The above-mentioned barriers do not appear to be capable of assuring extended barrier integrity alone. However, they may be used as secondary barriers to enhance the lifetime of other primary materials such as metals, alloys, and concretes. 


\section{SUMMARY}

A brief review has been conducted on a range of barrier materials for service in seawater environments. Some of the information was from coastal seawater studies, while other data are from actual specimens and structures that have been retrieved from ocean disposal sites. Some conceptual low-level waste package designs have already been specified (Figures 6.1 and 6.2) in which these materials may be used together to enhance service in seawater environments $[101,102]$. More recent studies have used prior data to estimate the performance of barrier materials in the deep ocean $[103,104]$. The work shows that there remains considerable uncertainty with respect to estimating barrier life. Much of this stems from the variability of conditions in the ocean from depth to depth and site to site. The most valuable data are those obtained from the retrieved waste drums since they represent detailed measurements of corrosion rates under well-defined disposal conditions. The other invaluable source of corrosion results are those from the scoping studies on a wide range of metallic materials exposed in test racks in the North Atlantic. A combination of this information provides the main basis for estimating the continued performance of materials at waste disposal sites. 


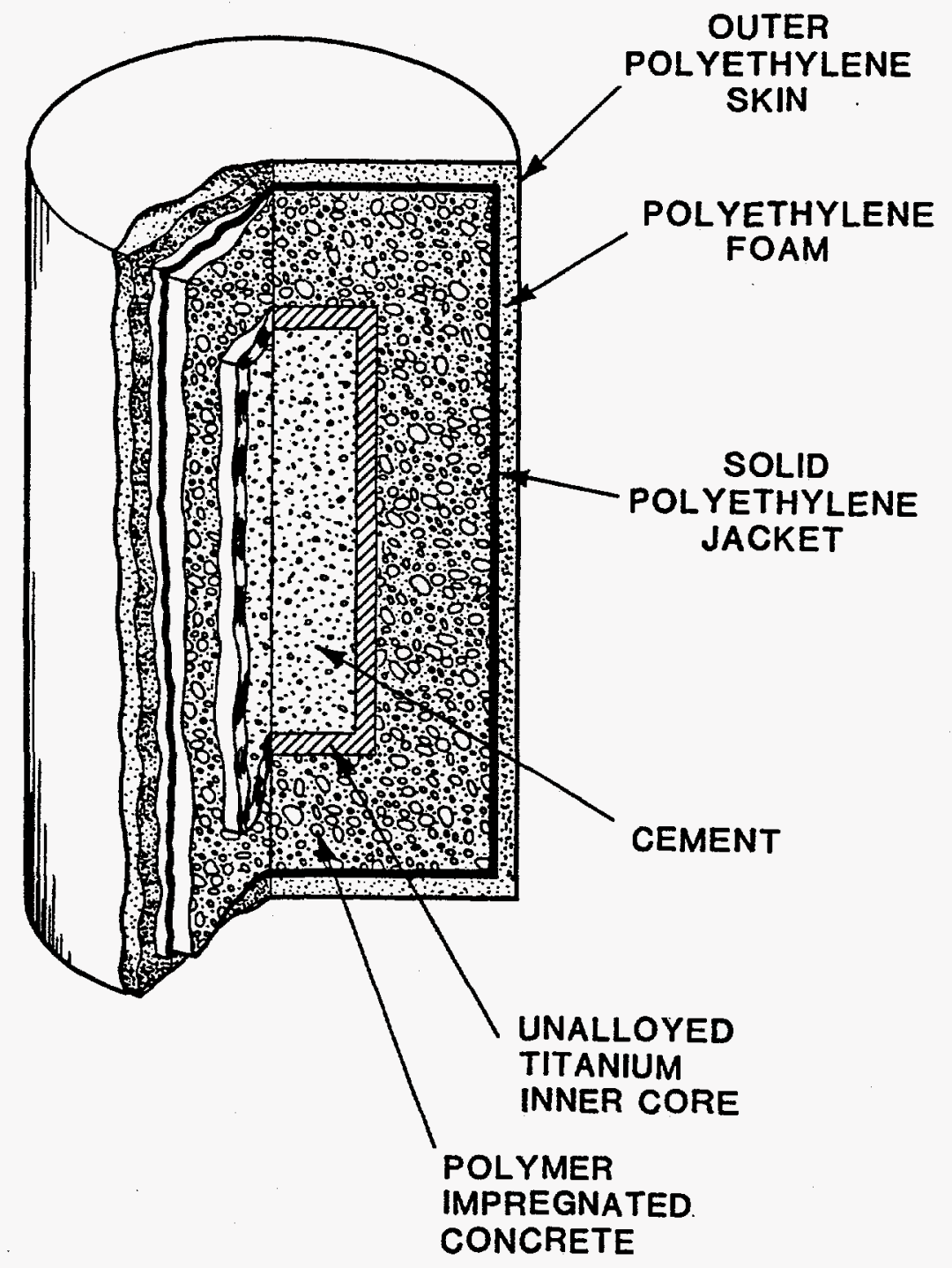

Figure 6.1 Proposed multibarrier waste package [101]. 


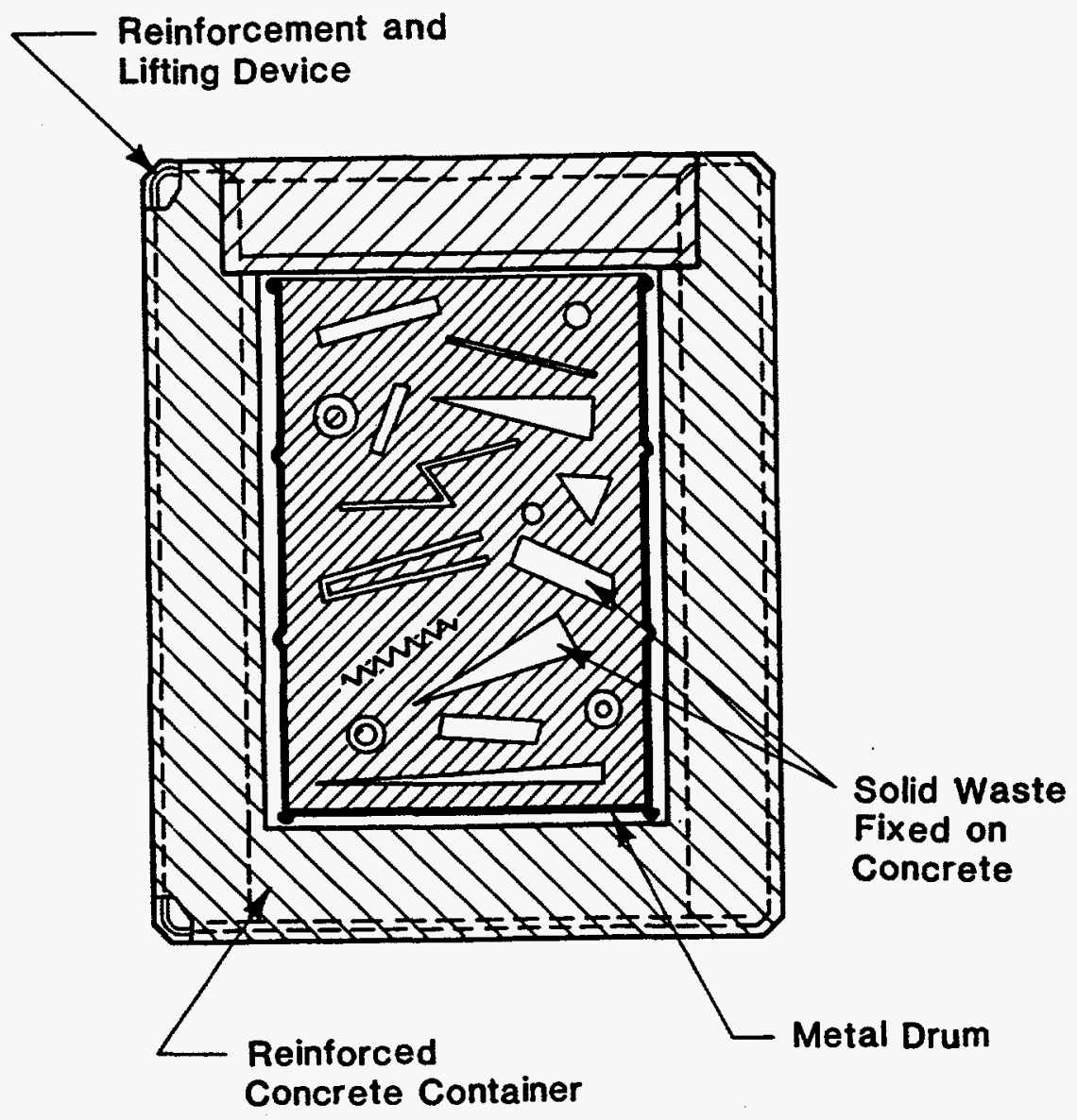

Figure 6.2 Steel waste container set in concrete container [102]. 


\section{REFERENCES}

1. Dyer, R.S., "Sea Disposal of Nuclear Waste: A Brief History," Nuclear Waste Management - The Ocean Alternative, T.C. Jackson (Edit.), Chap.3, Pergamom Press, New York, 1981.

2. Colombo, P., et al., "Analysis and Evaluation of a Radioactive Waste Package Retrieved from the Atlantic 2800 Meter Disposal Site," Brookhaven National Laboratory, BNL-51102, 1982.

3. Colombo, P. and M.W. Kendig, "Analysis and Evaluation of a Radioactive Waste Package Retrieved from the Farallon Islands 900-Meter Disposal Site," Brookhaven National Laboratory, BNL-45188, 1990.

4. Colombo, P., M.W. Kendig, and M. Fuhrmann, "Analysis and Evaluation of a Waste Package Retrieved from the Atlantic 3800-Meter Low-Level Radioactive Waste Disposal Site," EPA 402-R-93-004, 1993.

5. Dexter, S.C. and C. Culberson, "Global Variability of Natural Sea Water, " Materials Performance, 19 (9), 1980.

6. Knauss, J.A., Introduction to Physical Oceanography, Prentice-Hall, NJ, 1978.

7. Vetter, R.C., ed. Oceanography, Basic Books, Inc. , NY, 1973.

8. United States Dept. of the Navy, Draft Environmental Impact Statement on "The Disposal of Decommissioned, Defueled Naval Submarine Reactor Plants," Dec. 1982.

9. International Nickel Co., "Corrosion Resistance of the Austenitic Chromium-Nickel Stainless Steels in Marine Environments, " Bulletin A-319, 1963.

10. Schumacher, M., Seawater Corrosion Handbook, Noyes Data Corp., New Jersey, 1979.

11. Shreir, L.L., (Edit.), Corrosion, Vol. 1, Newnes-Butterworth, London, 1979, pp 2:51 to $2: 60$.

12. American Society for Metals, Metals Handbook - Ninth Edition, Vol. 1, ASM, 1979, pp 741-476.

13. American Society for Metals, Metals Handbook - Desk Edition. ASM, 1985, pp 4-92 to 4-93.

14. American Society for Metals, Metals Handbook - Ninth Edition. Vol. 13, ASM, 1984.

15. Fontana, M.G., Corrosion Engineering, McGraw-Hill, 1986, pp 373-378. 


\section{REFERENCES (cont.)}

16. Kowaka, M., Metal Corrosion Damage and Protection Technology, Allenton Press, Inc., 1990.

17. Dexter, S.C., "Material for Containment of Low-Level Nuclear Waste in the Deep Ocean," EPA 520/1-82-005, 1982.

18. Bohni, H., and H.H. Uhlig, J. Electrochem Soc., 116, 1969.

19. Baboian, R., et al., "Galvanic and Pitting Corrosion - Field and Laboratory Studies," ASTM STP 576, American Society for Testing and Materials, 1974.

20. Boyd, W.K. and F.W. Fink, "Corrosion of Metals in Marine Environments," Battelle Columbus Laboratories, MCIC-78-37, 1978.

21. Uhlig, H.H. and R.W. Revie, Corrosion and Corrosion Control, 3rd, ed., WileyInterscience, NY, 1985.

22. France, W.D., Jr., “Crevice Corrosion of Metals in Localized Corrosion - Cause of Metal Failure,” ASTM STP 516, American Society for Testing and Materials, 1972.

23. Sheir, L.L., ed., Corrosion, Vol. 1, "Metal/Environment Reactions," NewesButterworth, London, 1979.

24. La Que, F.L., "Corrosion Testing," Proc. of ASTM, 51, American Society for Testing and Materials, pp. 495-582, 1951.

25. La Que, F.L., Marine Corrosion, Wiley-Interscience, NY, 1975.

26. Dexter, S.C., Handbook of Oceanographic Engineering Materials, Wiley-Interscience, 1979.

27. Tuthill, A.H. and C.M. Schillmoller, "Guidelines for Selection of Marine Materials," 2nd, ed., The International Nickel, Co., 1971.

28. George, P.F., et al., Desalination Materials Manual, Dow Chemical Company, for the Dept. of the Interior, 1975.

29. Staehle, R.W., "Stress Corrosion Cracking of the Fe-Cr-Ni Alloy System," The Theory of Stress Corrosion Cracking in Alloys, Proceedings of a Research Evaluation Conference, Scully, J.C., ed., NATO Scientific Affairs Division, Brussels, 1971.

30. International Nickel Co., "Corrosion Resistance of the Austenitic Chromium-Nickel Stainless Steels in Chemical Environments," Bulletin A-317, INCO, 1963. 
REFERENCES (cont.)

31. Reinhart, F.M., "Corrosion of Metals and Alloys in the Deep Ocean," Civil Engineering Laboratory, TR-834, 1976.

32. Larrabee, C.P., "Corrosion of Steels in Marine Atmospheres and in Sea Water," Trans. Electro Chemical Soc., 87, 161 (1945).

33. Larrabee, C.P., "Corrosion Resistance of High-Strength Low Alloy Steels as Influenced by Composition and Environment," Corrosion, 9(8), 1953.

34. Reinhart, F.M., "Corrosion of Materials in Hydrospace - Part I. Irons, Steels, Cast Irons and Steel Products, " U.S. N.C.E.L., Technical Note N-900, 1967.

35. Suss, H., S.L. Williams, C.M. Barth, and R.B. Sheldon, "Corrosion Rates and Evaluations of Structural Materials in the North Atlantic Continental Rise," KAPL-4135, 1982.

36. Barth, C.H., and R.B. Sheldon, "Corrosion Rates of Structural Materials on the Ocean Floor," KAPL-401, 1989.

37. DiGregoria and J.P. Fraser, "Corrosion Tests in the Gulf Floor," in Corrosion in Natural Environments, ASTM Spec. Tech. Publication, STP 558, pp 185-208, 1974.

38. Southwell, C.R. and A.L. Alexander, "Corrosion of Structural Ferrous Metals in Tropical Environments - Sixteen Years Exposure to Sea and Fresh Water," 1968 NACE Conference, Ohio, paper No. 14, 1968.

39. Merz, M.D., State-of-the-Art Report on "Corrosion Data Pertaining to Metallic Barriers for Nuclear Waste Repositories," MCC, Pacific Northwest Laboratory, PNL-4474, 1982.

40. Whitman, W., et al., Ind. Eng. Chem., 16, 665, 1924.

41. LaQue, F.L., The Corrosion Handbook, Wiley, New York, p.384, 1984.

42. Schmitt, R.J. and E.M. Phelps, "Corrosion Performance of Constructional Steels in Marine Applications," J. Metals, Mar., 1970.

43. Maeda, S. and Y. Wadachi, "Seawater Corrosion Tests for Low-Level Radioactive Drum Containers," JAERI-M (85-181), 1985.

44. Rynewicz, J.F., "Evaluation of Paint Coatings Tested in the Deep Atlantic and Pacific Oceans," in Corrosion in Natural Environments, ASTM Spec. Tech Publication, STP 558, ASTM, pp 209-235, 1974. 


\section{REFERENCES (cont.)}

45. American Society for Metals, Metals Handbook - Ninth Edition, Vol.13, ASM, p.523, 1987.

46. International Nickel Co., "Corrosion Resistance of the Austenitic Chromium-Nickel Stainless Steels in Marine Environments," Bulletin A-319, 1963.

47. MTI, "Experience Survey: Stress Corrosion Cracking of Austenitic Stainless Steels in Water," Publication \#28, Materials Technology Institute of the Chemical Process Industries, Inc., 1987.

48. Giffin, R.H. "Seawater Corrosion Experiment: Results from One Year of Exposure," Bettis Atomic Power Laboratory, Pittsburgh, PA, Report. WAPD-TM-1511, 1982.

49. Dayal, R., et al., "Nuclear Waste Management Technical Support in its Development of Nuclear Waste Form Criteria for the NRC, Task I Waste Package Overview," Brookhaven National Laboratory, BNL-NUREG-51484, Vol. 1, 1982.

50. Braithwaite, J.W., et al., "Titanium Alloy Corrosion in Nuclear Waste Environments," Corrosion 80, paper No. 213, 1980.

51. Bomberger, H.B., et al., "Corrosion Properties of the Titanium in Marine Environments," J. of the Electrochem. Soc., 101, (9), 1954.

52. "Titanium Heat Exchangers for Service in Seawater, Brine, and Other Aqueous Environments," Titanium Inf. Bull., from IMI, Birmingham, 1976.

53. Lustman, B. and F. Kerze, Jr., ed., The Metallurgy of Zirconium, McGraw Hill, 1955.

54. Yau, T., "The Erosion Properties of Zirconium Alloys in Chloride Solutions," Corrosion 83, paper No. 26, 1983.

55. Smyrl, L.L. Stephenson, and J.W. Braithwaite, "Behavior of Candidate Materials in Deep Ocean Environments," SAND77-0243, Sandia National Laboratories, 1977

56. Osborn, D.H. and D.A. Sudrabin, "Copper Base Alloys: The Logical Choice for Marine Structures and Equipment," 1969 NACE Conf., Texas, paper No. 70, 1969.

57. Popplewell, J.M., "Marine Corrosion of Copper Alloys: An Overview, " Corrosion 78, paper No. 21, Texas, 1978.

58. Reinhardt, F.M., "Corrosion of Copper Alloys in Hydrospace," Corrosion in Normal Environments, ASTM, Spec. Tech. Pub. \#STP-558, 1973. 
REFERENCES (cont.)

59. Hummer, C.W., et al., "Corrosion of Metals in Tropical Environments - Copper and Wrought Copper Alloys," Materials Protection, 7(1), 1968.

60. Gilbert, P.T., "A Review of Recent Work on Corrosion Behavior of Copper Alloys in Seawater," Corrosion 81, paper No. 194, 1981.

61. Syrett, B.C., et al., "Corrosion of Copper - Nickel Alloys in Seawater Polluted with Sulfides and Sulfide Oxidation Products," Corrosion 79, paper No. 233, 1979.

62. Mac Donald, D.D., et al., "The Corrosion of Cu-Ni Alloys 706 and 715 in Flowing Seawater. II-Effect of Dissolved Sulfide," Corrosion (35)8, 1979.

63. Lennox, T.J., et al., "Corrosion Resistance and Response to Cathodic Protection of Advanced Alloys in Seawater," Corrosion 83, paper No. 64, 1983.

64. Reinhart, F.M., "Corrosion of Nickel and Nickel Alloys in Deep Ocean Environments," Corrosion 68, paper No. 17, 1968.

65. Meissner, H., "Sea-water-in Situ Experiments Using Aluminum Materials in the Arabian Gulf," Aluminum, 61, (2), 1985.

66. Von Franhofer, J.A., "Lead Corrosion in Seawater," Anti-Corrosion, 16(5), 1969.

67. Southwell, C.R., et al., "Corrosion of Metals in Tropical Environments, Part 1 - Five Non-Ferrous Metals and a Structural Steel," Corrosion, 14(2), 1958.

68. Haynes, H.H. and R.S. Highber, "Concrete Properties at Ocean Depths," Journal of the Waterways, Harbors, and Coastal Engineering Division, Proceedings of the American Society of Civil Engineers, 102(WW4), Nov. 1976.

69. Derucher, K.N. and C.P. Heins, Materials for Civil and Highway Engineers, PrenticeHall, Inc., 1981.

70. Biczok, I., Concrete Corrosion Concrete Protection, Akademiai Kiado, Budapest, 1972.

71. Mehta, P.K., "Durability of Concrete in Marine Environment - A Review," Performance of Concrete in Marine Environment, ACI SP-65, American Concrete Institute, 1980.

72. Seki, S., and Amano, H., "Integrity Test of Full Size Packages of Cement-Solidification Radioactive Wastes Under Deep-Sea Conditions," Nuclear and Chem. Waste Mgmt., Vol. 1, Pergamon Press Ltd., 1980. 


\section{REFERENCES (cont.)}

73. Kalousek, G.L., et al., "Concrete for Long-Time Service in Sulfate Environment," Cement and Concrete Research, Vol. 2, Pergamon Press, Inc., 1972.

74. Muraoka, J.S., "Effect of the Deep Ocean Environment on Plastics," Materials Performance and the Deep Sea, ASTM STP 445, American Society for Testing and Materials, 1968.

75. Mehta, P.K. and H.H. Haynes, "Durability of Concrete in Seawater," J. of the Structural Division, ASCE, 101, ST8, 11516, 1975.

76. Haderlie, E.C., "Marine Borers, Potential Threat to Concrete and Polymeric Materials in OTEC Systems," Proceedings of the OTEC Biofouling and Corrosion Symposium, Seattle, 1978.

77. Lea, F.M., The Chemistry of Cement and Concrete, 3rd, ed., Chemical Publishing Company, Inc., NY, 1971.

78. Mehta, P.K. and H.H. Haynes, "Durability of Concrete in Seawater," Journal of the Structural Division, Proceedings of the American Society of Civil Engineers, 101(ST8), 1975.

79. Fluss, P.K. and S.S. Gormam, Discussion of the paper, "Use of Concrete in Marine Environments," Wakeman, et al., Proceedings of the Journal of American Concrete Institute, 54, pp. 1309-46, 1958, see also Wakeman, C.M., et al., Ibid, pp. 841-856.

80. Powers, T.C., et al., "Permeability of Portland Cement Paste, Proceedings, Journal of the American Concrete Institute, 51, 1954.

81. Haynes, H.H., "Permeability of Concrete in Seawater," Performance of Concrete in Marine Environment, American Concrete Institute, ACI SP-65, 1980.

82. Hartt, W.H., et al., "Cracking of Concrete in Seawater Due to Embedded Metal Corrosion," Corrosion 78, National Association of Corrosion Engineers, paper No. 72, 1978.

83. Fidjestoal, P. and N. Nilsen, "Field Test of Reinforcement Corrosion in Concrete," Performance of Concrete in Marine Environment, ACI SP-65, American Concrete Institute, 1980.

84. Makita, M., et al., "Performance of Typical Protection Methods for Reinforced Concrete in Marine Environment, " Performance of Concrete in Marine Environment, ACI SP-65, American Concrete Society, 1980. 


\section{REFERENCES (cont.)}

85. Kukacka, L.E., et al., "Concrete-Polymer Composites for Underwater Applications," Brookhaven National Laboratory, BNL-50313, 1971.

86. Steinberg, M., "Concrete-Polymer Materials Development, A Goal-Oriented Program," Brookhaven National Laboratory, BNL-50313, 1971.

87. Rayfiel, R., and L.E. Kukacka, "Development of a Glass Polymer Composite Sewer Pipe from Waste Glass, " Final Report, Brookhaven National Laboratory, BNL-51194, 1980.

88. Bares, R.A., ed., "Plastics in Material and Structural Engineering, " Proceedings of the ICP/RILEM/IBK International Symposium, Topic 2, Subtopics B and C, 1981.

89. Araki, A.K., et al., "PIC-Container for Containment and Disposal of Low-and Intermediate-Level Radioactive Wastes," Japan Atomic Energy Research Institute, JAERI-M-9389, 1981.

90. Chichibu Cement Co., Ltd., "PIC (Polymer Impregnated Concrete) Container for Processing and Disposal of the Low- to Intermediate-Level Radioactive Wastes," Technical Report form Chichibu Cement Co., Ltd., Japan, 1982.

91. Connolly, R.A., "Effect of Seven-Year Marine Exposure on Organic Materials," Materials Research and Standards, $\underline{3}, 193,1963$.

92. Connolly, R.A., et a1., "Marine Exposure of Polymeric Materials and Cables After Fifteen Years," J. of Materials, $\underline{5}, 539,1970$.

93. Wolock, I., "Polymeric Materials and Composites," in Seawater Corrosion Handbook, ed., M. Schumacher, Noyes Data Corp., 1979.

94. Bowerman, B.S., et al., "An Evaluation of the Stability Tests Recommended in the Branch Technical Position on Waste Forms and Container Materials, "Brookhaven National Laboratory, BNL-NUREG-51784, 1985.

95. Phillips, J.W., "Evaluation and Testing of High Integrity Containers," American Nuclear Society 1982 Winter Meeting.

96. Kalb, P.D. and P. Colombo, "Polyethylene Solidification of Low-Level Wastes," Brookhaven National Laboratory, BNL-51867, 1984.

97. Soo, P., et al., "The Effects of Environment and Gamma Irradiation on the Mechanical Properties of High-Density Polyethylene," Brookhaven National Laboratory, NUREG/CR-4607, 1986. 


\section{REFERENCES (cont.)}

98. Soo, P., et al., "A Study of the Use of Cross Linked High-Density Polyethylene for Low-Level Radioactive Waste Containers," Brookhaven National Laboratory, NUREG/CR-5363, 1989.

99. Soo, P., et al., "The Extended Storage of Radioactive Ion-Exchange Resins in Polyethylene High Integrity Containers," Brookhaven National Laboratory, BNL-52429, 1994.

100. Snellman, M. and M. Valkiainen, "Long-Term Properties of Bituminized Waste Products," Technical Research Center of Finland, 1985.

101. Dexter, S.C., "Materials for Containment of Low-Level Nuclear Waste in the Deep Ocean," EPA 520/1-82-005, 1982.

102. Nuclear Energy Agency, "Guidelines for Sea Dumping Packages of Radioactive Waste," Un-numbered report, Office of Economic Co-operation and Development, Paris, 1979.

103. Carter, J.H., "Corrosion of "Lenin" Reactor Compartment Materials," Report \#RNC/NS/TM431, May 1994, Department of Nuclear Science and Technology, Royal Naval College, Greenwich, UK.

104. Sheldon, R.B., "Environmental Assessment of the Sinking of the Nuclear Powered Submarines Thresher and Scorpion," Waste Management '95, Paper 60-7, Tucson, AZ, 1995. 